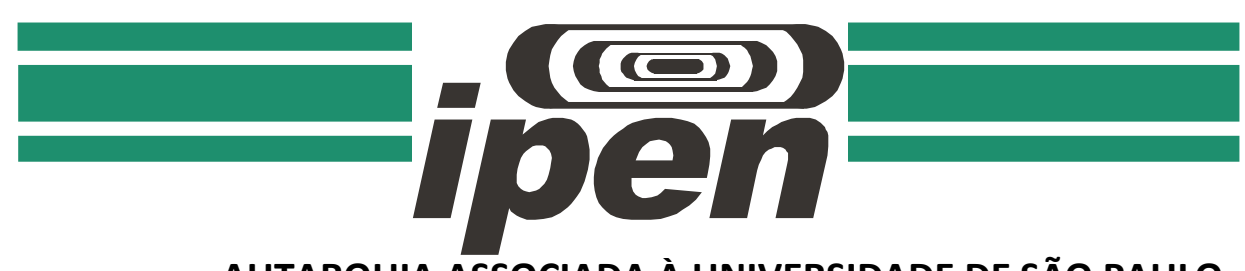

AUTARQUIA ASSOCIADA À UNIVERSIDADE DE SÃO PAULO

APLICAÇÃO DE MAPAS AUTO-ORGANIZÁVEIS NA CLASSIFICAÇÃO DE ABERRAÇÕES CROMOSSÔMICAS UTILIZANDO IMAGENS DE CROMOSSOMOS HUMANOS SUBMETIDOS À RADIAÇÃO IONIZANTE

KELLY DE PAULA CUNHA

Dissertação apresentada como parte dos requisitos para obtenção do Grau de Mestre em Ciências na Área de Tecnologia Nuclear - Reatores

Orientador:

Prof. Dr. Roberto Navarro de Mesquita 
INSTITUTO DE PESQUISAS ENERGÉTICAS E NUCLEARES

Autarquia associada à Universidade de São Paulo

\section{APLICAÇÃO DE MAPAS AUTO-ORGANIZÁVEIS NA CLASSIFICAÇÃO DE ABERRAÇÕES CROMOSSÔMICAS UTILIZANDO IMAGENS DE CROMOSSOMOS HUMANOS SUBMETIDOS À RADIAÇÃO IONIZANTE}

Kelly de Paula Cunha

Dissertação apresentada como parte dos requisitos para obtenção do Grau de Mestre em Ciências na Área de Tecnologia Nuclear - Reatores

Orientador:

Prof. Dr. Roberto Navarro de Mesquita

Versão Corrigida

Versão Original disponível no IPEN

São Paulo

2015 


\section{AGRADECIMENTOS}

Ao prof. Dr. Roberto Navarro de Mesquita sem o qual este trabalho seria impossível. Às Dr. Kayo Okazaki e Dr. Márcia Augusta da Silva pela colaboração inestimável. À Flávia Valgôde pelos esclarecimentos importantes.

Aos Dr. Paulo Masotti e Dr. Sérgio Perillo por todos os ensinamentos.

Ao meu Noivo por ser o maior incentivador na superação dos meus limites.

À minha Mãe e meu irmão pelo incentivo em horas difíceis.

À minha avó Maria dos Reis por estar sempre presente.

Aos meus amigos Júlia, e Leandro pela paciência e companhia.

Ao IPEN (Instituto de Pesquisas Energéticas Nucleares).

Ao CEN-IPEN (Centro de Engenharia Nuclear).

Ao CB-IPEN (Centro de Biotecnologia).

Ao CNPQ pelo financiamento dessa pesquisa. 


\title{
APLICAÇÃO DE MAPAS AUTO-ORGANIZÁVEIS NA CLASSIFICAÇÃO DE ABERRAÇÕES CROMOSSÔMICAS UTILIZANDO IMAGENS DE CROMOSSOMOS HUMANOS SUBMETIDOS À RADIAÇÃO IONIZANTE
}

\author{
Kelly de Paula Cunha
}

\begin{abstract}
RESUMO
O presente trabalho é resultado da colaboração de pesquisadores do Centro de Engenharia Nuclear (CEN) e de pesquisadores do Centro de Biotecnologia (CB), ambos pertencentes ao IPEN, para o desenvolvimento de uma metodologia que visa auxiliar os profissionais citogeneticistas fornecendo uma ferramenta que automatize parte da rotina necessária para a avaliação qualitativa e quantitativa de danos biológicos em termos de aberração cromossômica. A técnica citogenética, sobre a qual esta ferramenta é desenvolvida, é a técnica de aberrações cromossômicas. Nela, são realizadas preparações citológicas de linfócitos de sangue periférico para que metáfases sejam analisadas e fotografadas ao microscópio e, com base na morfologia dos cromossomos, anomalias sejam investigadas. Quando esta tarefa é realizada manualmente, os cromossomos são analisados visualmente um a um pelo profissional citogeneticista, logo, trata-se de um processo minucioso em virtude da variação geral na aparência do cromossomo, do seu tamanho pequeno e do grande número de cromossomos por célula. Para um diagnóstico confiável, é necessário que várias células sejam analisadas, tornando-se uma tarefa repetitiva e demorada. Neste contexto, foi proposto o uso dos mapas auto-organizáveis para o reconhecimento automático de padrões morfológicos referentes às imagens de cromossomos humanos. Para isso, foi desenvolvido um método de extração de características por meio do qual é possível classificar os cromossomos em: dicêntricos, anéis, acrocêntricos, submetacêntricos e metacêntricos, com acerto de 93,4 \% em relação ao diagnóstico dado por um profissional citogeneticista.
\end{abstract}

Palavras-chave: aberrações cromossômicas; classificação cromossômica; diagnóstico por imagem; mapas auto-organizáveis; redes de Kohonen, redes neurais artificiais. 


\title{
APPLICATION OF SELF-ORGANIZING MAPS FOR THE CLASSIFICATION OF CHROMOSOMAL ABERRATIONS USING IMAGES OF HUMAN CHROMOSOMES SUBJECTED TO IONIZING RADIATION
}

\author{
Kelly de Paula Cunha
}

\begin{abstract}
This work is a joint collaboration between Nuclear Energy Research Institute (IPEN), Nuclear Engineering Center and Biotechnology Center to develop a methodology aiming to assist cytogenetic professionals by providing a tool to automate part of the required routine to perform qualitative and quantitative evaluation of biological damage in terms of chromosomal aberration. The cytogenetic technique upon which this tool was developed, is the chromosome aberrations technique, in which cytological preparations of peripheral blood lymphocyte metaphases are performed to be analyzed and photographed under a microscope in order to investigating chromosomal aberration. Performed manually, the chromosomes are analyzed visually one by one by a cytogenetic professional, so it is a painstaking process due to the great deal of variation in the appearance of each chromosome, their small sizes and not to mention the high density of chromosomes per cell. In order to obtain a reliable diagnosis it is necessary that many cells be analyzed, which makes this a repetitive and time consuming process. In this context, the use of self-organizing maps for the automatic recognition of patterns relating to morphological pictures of human chromosomes has been proposed. For this, we developed a feature extraction method by which is possible to classify chromosomes in: dicentrics, ring-shaped, acrocentric, submetacentric and metacentric with $93.4 \%$ accuracy compared to diagnostic given by a professional cytogeneticist.
\end{abstract}

Keywords: chromosomal aberrations; chromosome classification; diagnostic imaging; self-organizing maps; Kohonen networks, artificial neural networks. 


\section{SUMÁRIO}

Página

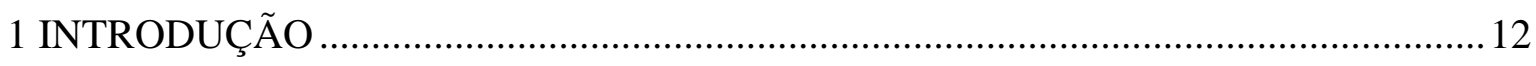

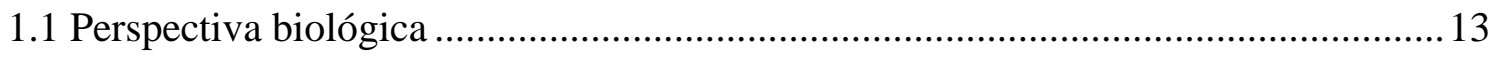

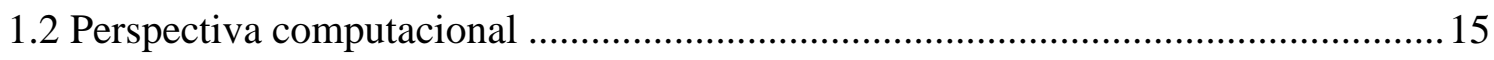

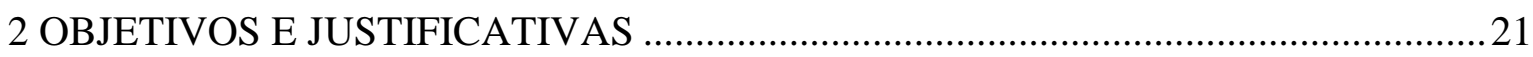

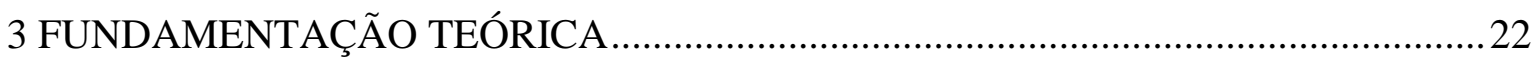

3. 1 Considerações gerais sobre a radiação ionizante .................................................... 22

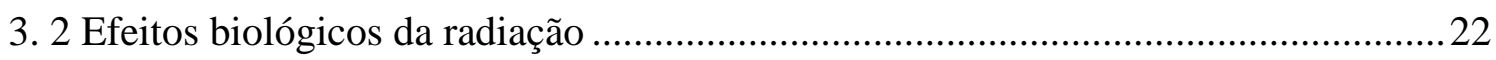

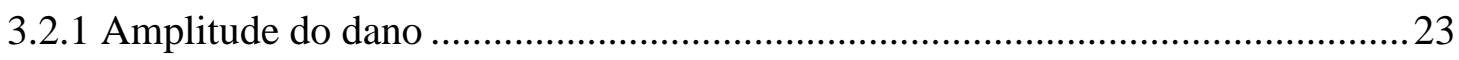

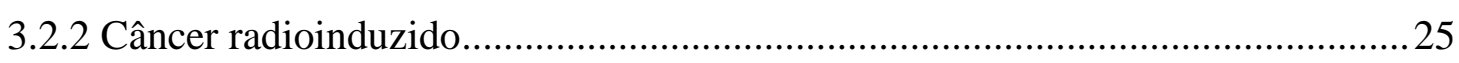

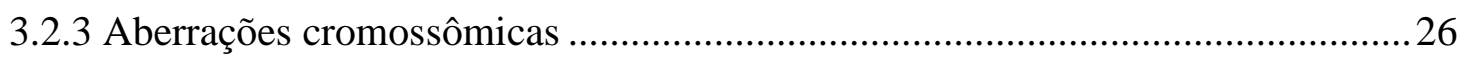

3.3 Considerações gerais sobre técnicas de análise cromossômica ................................ 38

3.3.1 Técnica de aberrações cromossômicas .............................................................. 40

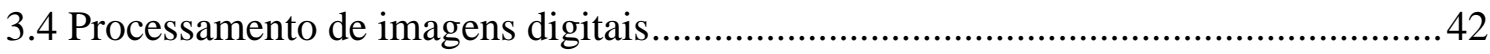

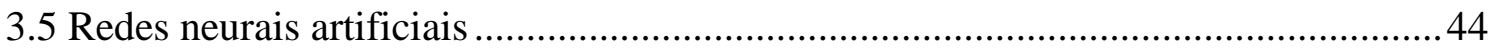

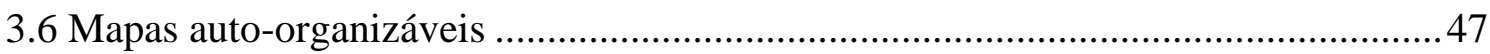

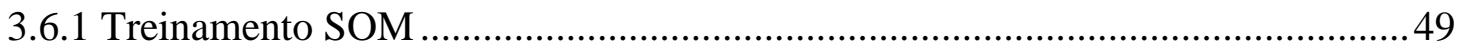

3.6.2 Criação e configuração da rede no SOM Toolbox ............................................50

3.6.3 Práticas recomendadas para a construção de um bom mapa ................................55

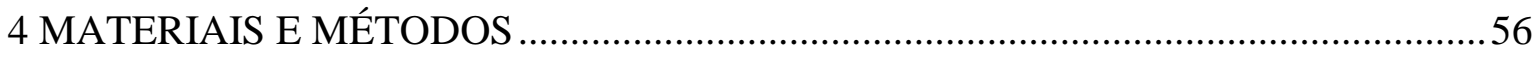

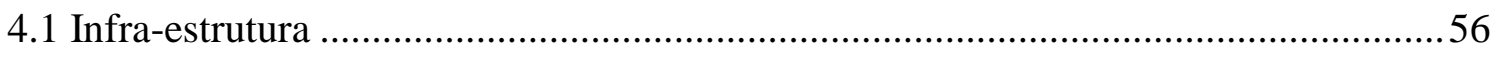

4.1.1 Dependências do reator de pesquisa (IEA-R1) ................................................56

4.1.2 Laboratório de Cultura Celular do Centro de Biotecnologia (CB) ......................56

4.1.3 Equipamento e sistema operacional para o desenvolvimento do aplicativo .......57

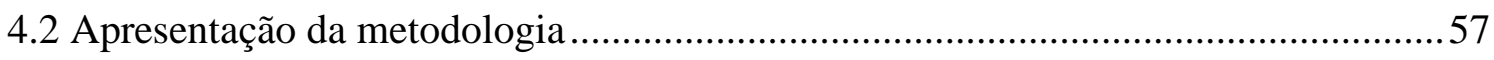


4.2.1 Aquisição das imagens de células metafásicas

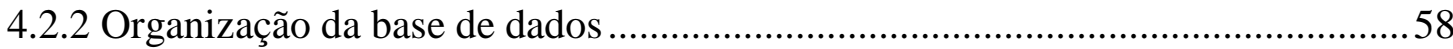

4.2.3 Individualização dos cromossomos em subimagens independentes ....................59

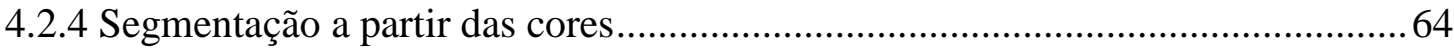

4.2.5 Classificação das aberrações cromossômicas........................................................66

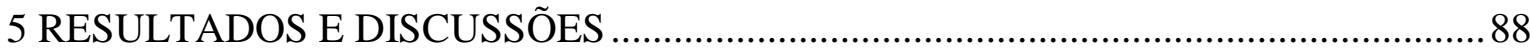

5.1 Conjunto de dados utilizados para obtenção do resultado final................................. 89

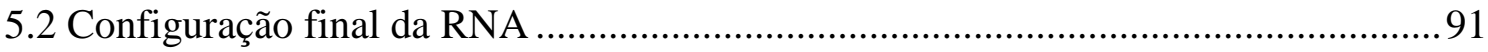

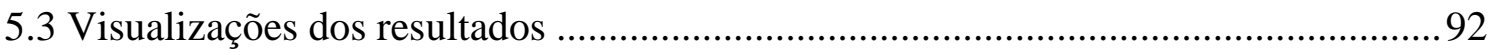

6 CONCLUSÕES E SUGESTÕES PARA TRABALHOS FUTUROS ............................97

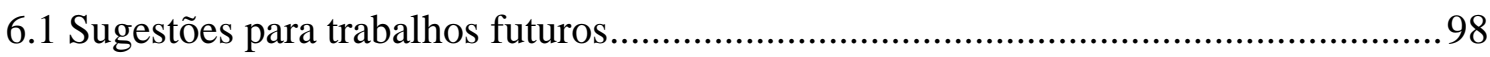




\section{LISTA DE FIGURAS}

\section{Página}

FIGURA 1 - Curva dose-resposta para a aberração em linfócitos humanos produzidos por

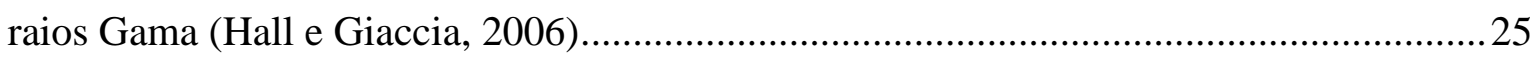

FIGURA 2 - Fases da divisão mitótica (Cooper e Hausman, 2007) ...................................2 27

FIGURA 3 - Estrutura do cromossomo metafásico (Lemm, 2012) ...................................2 28

FIGURA 4 - Tipos de cromossomos: A) metacêntrico, B) submetacêntrico, C) acrocêntrico, D) telocêntrico (Lemm, 2012) 28

FIGURA 5 - Relação entre o tipo de aberração e o estágio no ciclo celular no momento da irradiação (Buckton e Evans, 1973). 30 FIGURA 6 - Aberrações do tipo cromossômico na mitose (Adaptado de Buckton e Evans, 1973). 31

FIGURA 7 - Célula humana metafásica que apresenta uma ocorrência de fragmentos acêntricos (Cedida pela equipe do Centro de Biotecnologia IPEN/CNEN)

FIGURA 8 - Deleção intersticial antes da replicação celular (Hall e Giaccia, 2006) 32

FIGURA 9 - Célula humana metafásica que apresenta duas ocorrências de deleção pontual (Cedida pela equipe do Centro de Biotecnologia IPEN/CNEN)

FIGURA 10 - Passos para a formação de um cromossomo em anel cêntrico (Adaptado de Hall e Giaccia, 2006)

FIGURA 11 - Célula humana metafásica que apresenta uma ocorrência de cromossomo em anel cêntrico (Buckton e Evans, 1973)

FIGURA 12 - Célula humana metafásica que apresenta três ocorrências de cromossomos em anel acêntricos (Buckton e Evans, 1973).

FIGURA 13 - Ilustração da formação de uma inversão pericêntrica (Pereira, 2010) 35

FIGURA 14 - Passos para a formação de um cromossomo dicêntrico (Adaptado de Hall e Giaccia, 2006)

FIGURA 15 - Célula humana metafásica que apresenta uma translocação assimétrica dicêntrica (Buckton e Evans, 1973).

FIGURA 16 - Ilustração da formação de uma translocação simétrica (Hall e Giaccia, 2006)

FIGURA 17 - Célula humana metafásica que apresenta uma quebra cromatídica (Buckton e Evans, 1973).

FIGURA 18 - Cariótipo que apresenta lacuna cromatídica (Buckton e Evans, 1973) 38 
FIGURA 19 - Cariótipo de cromossomos humanos (Hsu, 1979 apud Carr, 2014).

FIGURA 20 - Modelo de neurônio de McCulloch-Pitts (Da Silva Filho, 2012).....

FIGURA 21 - Exemplo de arquitetura de rede neural artificial (Caudill e Butler, 1989) ...47

FIGURA 22 - Exemplos de vizinhança discreta: (a) Estrutura Hexagonal e (b) Estrutura retangular (Vesanto et al., 2000b)

FIGURA 23 - Diferentes formatos do mapa: (a) o formato de folha (sheet), (b) cilíndrico

(cylinder), e (c) toroide (toroid) (Vesanto et al., 2000b)

FIGURA 24 - Etapas pelas quais as imagens de células metafásicas são submetidas para se obter imagens de cromossomos individualizados e reposicionados

FIGURA 25 - A) Histograma de intensidades da imagem em tons de cinza; B) Histograma de intensidades da imagem após a aplicação do ajuste de contraste (Souza, 2011) 61

FIGURA 26 - Comparação entre diferentes técnicas de segmentação aplicadas em imagem de célula humana metafásica .65

FIGURA 27 - Tabela de dados (Vesanto et al., 2000b) 66

FIGURA 28 - Exemplificação da interpolação bilinear (Adaptado de Azevedo, 2011) .....68 Figura 29 - Mapa resultante do primeiro teste. A função 'som_clustercolor' foi utilizada para colorir cada um dos agrupamentos com uma cor diferente

FIGURA 30 - Representação das distâncias horizontais entre as bordas. As setas indicam a presença de constrições

FIGURA 31 - Ilustração da forma como é obtido um $D H B$. À esquerda uma imagem

bidimensional [120x60] que representa um cromossomo dicêntrico. À direita o gráfico do

$D H B$ desta imagem

FIGURA 32 - Mapa resultante do segundo teste. A função 'som_clustercolor' foi utilizada para colorir cada um dos agrupamentos com uma cor diferente

FIGURA 33 - Comparação entre dois gráficos de DHBs cuja amplitude dos ranges é diferente mas a curvatura do gráfico é idêntica. As setas indicam a presença de constrições. Ambos os gráficos foram obtidos a partir de um cromossomo dicêntrico e os ranges foram alterados apenas para ilustrar este exemplo 77

FIGURA 34 - Mapa resultante do terceiro teste. A função 'som_clustercolor' foi utilizada para colorir cada um dos clusters com uma cor diferente.

FIGURA 35 - Gráficos de DHBs obtidos a partir de imagens de cromossomos dicêntricos 
FIGURA 36 - Gráficos obtidos a partir da imagem de cromossomo dicêntrico, o gráfico superior refere-se ao $D H B$, o traço vermelho ilustra o limiar e o segundo gráfico mostra o DHB2

FIGURA 37 - Gráficos obtidos a partir do imagem do cromossomo dicêntrico localizado à esquerda. O gráfico superior refere-se ao $D H B$, o traço vermelho ilustra o limiar e o segundo gráfico mostra o $D H B 2$. As setas indicam constrições suaves que devem ser detectadas

FIGURA 38 - Gráficos obtidos a partir do imagem do cromossomo normal localizado à esquerda $\mathrm{O}$ gráfico superior refere-se ao $\mathrm{DHB}$, o traço vermelho ilustra o limiar e o segundo gráfico mostra o $D H B 2$. A seta indica uma constrição suave que não deve ser detectada

FIGURA 39 - Ilustração das bandas no DHB2.

FIGURA 40 - Representação do cálculo de distâncias entre um vetor de entrada e um vetor de protótipo de um mapa auto-organizável.

FIGURA 41 - Gráficos de DHB2s que apresentam uma banda. O gráfico da figura superior corresponde a um cromossomo do tipo acrocêntrico e o gráfico da figura inferior corresponde a um cromossomo do tipo anel.

FIGURA 42 - Gráficos de DHB2s que apresentam duas bandas. O gráfico da figura superior corresponde a um cromossomo normal do tipo metacêntrico e o gráfico da figura inferior corresponde a um cromossomo normal do tipo submetacêntrico..... .85

FIGURA 43 - Tanto os gráficos em A) representados a esquerda, quanto os gráficos em B) correspondem a imagens de cromossomos acrocêntricos. Os gráficos superiores correspondem aos $D H B s$, os gráficos centrais correspondem aos $D H B 2 s$, e os gráficos inferiores correspondem aos vetores redistribuídos.

FIGURA 44 - Gráficos obtidos a partir da imagem de um cromossomo normal metacêntrico. O gráfico superior refere-se ao $D H B 2$ e o inferior refere-se ao vetor redistribuído. 86

FIGURA 45 - Os gráficos obtidos correspondem a imagens de cromossomos dicêntricos, os gráficos superiores correspondem aos $D H B s$, os gráficos centrais correspondem aos $D H B 2 s$, e os gráficos inferiores correspondem aos vetores redistribuídos.

FIGURA 46 - Diagrama de sequência de transformações ao qual a imagem cromossômica redimensionada é submetida para se obter o vetor característico a ser inserido no SOM, estas etapas constituem o método de extração de características proposto neste trabalho .. 89 
FIGURA 47 - Imagens segmentadas e reposicionadas de cromossomos com aberração do tipo anel usadas no treinamento da rede neural artificial desenvolvida neste trabalho 90 FIGURA 48 - Imagens segmentadas e reposicionadas de cromossomos do tipo dicêntrico usadas no treinamento da rede neural artificial desenvolvida neste trabalho 90 FIGURA 49 - Imagens segmentadas e reposicionadas de cromossomo do tipo acrocêntrico, usadas no treinamento da rede neural artificial desenvolvida neste trabalho 90 FIGURA 50 - Imagens segmentadas e reposicionadas de cromossomos s do tipo submetacêntrico, usadas no treinamento da rede neural artificial desenvolvida neste trabalho 90

FIGURA 51 - Imagens segmentadas e reposicionadas de cromossomos do tipo metacêntrico, usadas no treinamento da rede neural artificial desenvolvida neste trabalho91 FIGURA 52 - Matriz de distâncias unificada (U-matrix) obtida após o treinamento da RNA. Na Figura os clusters estão destacados pelos números de 1 a 5 92 FIGURA 53 - Mapa formado após o treinamento da RNA. A função 'som_clustercolor' foi utilizada para colorir cada um dos clusters com uma cor diferente 93

FIGURA 54 - Visualização dos gráficos de vetores de protótipos para cada unidade do mapa. Os valores armazenados no codebook são mostrados seguindo a distribuição topológica do mapa 


\section{LISTA DE ABREVIATURAS E/OU SIGLAS}

BMU - Best Matching Unit (melhor unidade correspondente)

CAIS - Chromosome Analysis Intelligent System

CB - Centro de Biotecnologia

CEN - Centro de Engenharia Nuclear

CNEN - Conselho Nacional de Energia Nuclear

DHB - Distancia Horizontal entre Bordas

DNA - Ácido Desoxirribonucleico

FISH - Hibridização in situ Fluorescente

IA - Inteligência Artificial

IAEA - International Atomic Energy Agency

ICRP - International Commission on Radiological Protection

ICRU - International Commission on Radiation Units and Measurements

IEA R1 - Reator de Pesquisas IEA R1

IPEN - Instituto de Pesquisas Energéticas e Nucleares

ISCN - International System for Human Cytogenetic Nomenclature

LSP - Linfócitos Sanguíneos Periféricos

LVQ - Linear Vector Quantization

RGB - Red, Green, Blue (sistema de coloração)

RNA - Rede Neural Artificial

SOM - Self-Organizing Maps (Mapas Auto-Organizáveis) 


\section{INTRODUÇÃO}

Neste trabalho busca-se simular computacionalmente o conhecimento do profissional citogeneticista em analisar a morfologia dos cromossomos e detectar aberrações cromossômicas. Esta dissertação apresenta uma continuidade às pesquisas desenvolvidas pelo grupo de Inteligência Artificial e Aplicações do Centro de Engenharia Nuclear (CEN) - IPEN em colaboração com pesquisadores do Centro de Biotecnologia (CB) - IPEN, onde foi desenvolvido o trabalho Análise morfológica de imagens $e$ classificação de aberrações cromossômicas por meio de lógica Fuzzy (Souza, 2011), que é base para o presente trabalho.

Os sistemas que automatizam a análise cromossômica são constituídos de três etapas fundamentais: pré-processamento da imagem metafásica, análise do objeto de interesse e classificação do cromossomo. Estas etapas podem ser subdivididas em vários problemas específicos já que cada uma delas pode exigir conhecimentos característicos naquele domínio.

A metodologia proposta por Souza (2011) abrange desde a melhora da qualidade da imagem metafásica (pré-processamento) até a classificação dos cromossomos, e inclui as seguintes rotinas: transformação da imagem metafásica para escala de cinza; ajuste de contraste; eliminação do fundo; segmentação; registro; extração de características; e o uso de um sistema de inferência com lógica Fuzzy para a classificação dos cromossomos.

O presente trabalho, valendo-se da metodologia de pré-processamento de imagens desenvolvida por Souza (2011), concentra-se no desenvolvimento de uma metodologia de extração de características e classificação cromossômica, apoiada no uso dos mapas auto-organizáveis para agrupar (“clustering”) diferentes tipos de cromossomos.

O primeiro capítulo faz um levantamento das principais publicações relacionadas às duas diferentes áreas do conhecimento envolvidas neste trabalho, a primeira refere-se à perspectiva biológica na qual a pesquisa está fundamentada e a segunda refere-se à perspectiva computacional onde se descrevem técnicas para o desenvolvimento do sistema aqui proposto. O segundo capítulo descreve os objetivos deste trabalho e as justificativas. O terceiro capítulo aborda a fundamentação teórica, onde é apresentada uma introdução sobre a radiação ionizante, os efeitos biológicos da radiação, 
as principais técnicas de análise cromossômica, a automação da análise cromossômica, o reconhecimento de padrões em imagens e os mapas auto-organizáveis. O quarto item apresenta toda a metodologia empregada para o desenvolvimento deste trabalho. O quinto item expõe os resultados obtidos e discussões sobre os problemas encontrados. O sexto capítulo trata das conclusões e sugestões para trabalhos futuros. E, por fim, as referências bibliográficas.

\subsection{Perspectiva biológica}

Walther Flemming, um anatomista alemão, é considerado o fundador da ciência citogenética. Em 1882 ele publicou as primeiras ilustrações dos cromossomos humanos. Flemming também se referiu à porção corável do núcleo como cromatina, além de ter sido o primeiro a utilizar o termo mitose. A palavra cromossomo, foi introduzida em 1888 , por Waldeyer que significa "corpo colorido" em grego; nesta época vários cientistas começaram a formular a ideia de que os determinantes da hereditariedade são transportados pelos cromossomos. Em 1900, Sutton desenvolveu formalmente a chamada Teoria Cromossômica da Herança e combinou as disciplinas de Citologia e Genética para denominar o estudo dos cromossomos como Citogenética (Maluf e Riegel, 2011).

Em 1932, Waardenburg sugeriu que a síndrome de Down pudesse ser o resultado de uma anormalidade envolvendo os cromossomos. Em 1958, Lejeune, estudando os cromossomos de fibroblastos em cultura de pacientes com síndrome de Down, relatou que foi constatado um cromossomo extra em suas células. Não demorou muito tempo para que outras síndromes envolvendo os cromossomos fossem descobertas (Maluf e Riegel, 2011).

Em 1960, Nowell e Hungerford relataram a presença do "cromossomo Filadelfia", na leucemia mieloide crônica, evidenciando pela primeira vez, uma associação entre cromossomos e câncer. Descobertas como estas, impulsionaram a busca por tecnologias que viabilizassem o estudo dos cromossomos (Maluf e Riegel, 2011).

Entre outras aplicações, a citogenética possibilita a compreensão do efeito prejudicial no organismo, causado por diferentes agentes mutagênicos, como as radiações ionizantes, que são evidenciadas neste trabalho.

Nos primórdios da utilização das radiações ionizantes, os efeitos nocivos provocados por elas foram multiplicados pela precariedade dos aparelhos, pela falta de proteção adequada e pelo total desconhecimento das doses que estavam sendo ministradas 
e dos seus efeitos. Os pacientes, radiologistas e fabricantes de aparelhos de raios X, sofriam exposições exageradas e danosas (Okuno, 2013).

Os raios X foram descobertos em 1895, mas somente 30 anos depois, é que foi criada uma comissão com a finalidade de estabelecer grandezas e unidades de física das radiações, critérios de medidas e métodos de comparação, denominada International Commission on Radiation Units and Measurements (ICRU). Em 1925, foi criada a International Commission on Radiological Protection (ICRP), com a incumbência de elaborar normas de proteção radiológica e estabelecer limites de exposição à radiação ionizante para indivíduos ocupacionalmente expostos e para público em geral. Essas comissões ainda se reúnem com regularidade para elaborar novas normas ou atualizar as já existentes. Cada país tem um órgão que faz adequações nas normas internacionais e as adota para regulamentar o uso das radiações. No Brasil, tal órgão é a Comissão Nacional de Energia Nuclear (CNEN) (Okuno, 2013).

Quando as radiações ionizantes ocasionam danos ao material genético (DNA), caso ele não sofra reparação adequada durante o processo de replicação celular, estes danos podem conduzir para alterações no número ou estrutura normal do cromossomo, denominadas aberrações cromossômicas.

As aberrações cromossômicas podem ocorrer de forma espontânea; ou estimuladas (induzidas) por radiação, ou outros agentes genotóxicos. Contudo, a grande maioria ocorre de forma estimulada, uma vez que a frequência de aberrações espontâneas é de apenas $0.6 \%$ em células vivas (Natarajan, 2002).

As classificações de aberrações cromossômicas propostas neste trabalho, são baseadas nos critérios descritos em Buckton e Evans (1973). Este manual fornece informações sobre o estudo dos efeitos biológicos das radiações ionizantes, e o uso do diagnóstico de aberrações cromossômicas para dosimetria biológica.

As aberrações induzidas pela radiação, são classificadas de acordo com a fase do ciclo celular onde se dá a ação dos agentes genotóxicos, sendo elas: as do tipo cromossômico e as do tipo cromatídico (Buckton e Evans, 1973).

As aberrações do tipo cromossômico ocorrem antes da duplicação do DNA, são elas: fragmentos acêntricos (deleção terminal), minutos (deleção intersticial), anéis acêntricos e cêntricos e inversões pericêntricas, dicêntricos (translocações assimétricas), tricêntricos e translocações simétricas. As aberrações do tipo-cromatídico ocorrem após a 
duplicação do DNA e envolvem apenas uma das cromátides do cromossomo, são elas: quebras cromatídicas e lacunas.

A análise do cromossomo possibilita o diagnóstico de possíveis aberrações, e pode ser aplicada para estimar a dose de radiação que determinado indivíduo recebeu. Nesse caso, são realizadas investigações cromossômicas em indivíduos que se acredita terem sido expostos a agentes prejudiciais aos cromossomos, com o objetivo de fazer uma avaliação quantitativa do efeito biológico em termos de aberração cromossômica (Buckton e Evans, 1973).

Os cromossomos podem ser analisados por meio de um número crescente de tecnologias eficientes. Algumas destas técnicas, detectam desequilíbrio alélico (situação onde um alelo - genes que se encontram na mesma posição em cromossomos homólogos e que são responsáveis por determinar uma mesma característica - está perdido ou amplificado), outras técnicas, como a utilizada na metodologia deste trabalho, são apenas sensíveis às mudanças físicas na estrutura do genoma ou ao número de cópias.

Neste trabalho é utilizada a técnica citogenética de aberrações cromossômicas, na qual são realizadas preparações citológicas de linfócitos de sangue periférico para que metáfases sejam analisadas, e de acordo com a morfologia dos cromossomos, sejam identificadas possíveis anomalias microscopicamente visíveis. Trata-se de um processo minucioso devido à variação geral na aparência do cromossomo e dificultado pelo grande número de cromossomos por célula e pelo seu tamanho pequeno. Quando realizada manualmente, os cromossomos são analisados visualmente um a um pelo profissional citogeneticista, tornando-se uma tarefa repetitiva, demorada, e de certa forma imprecisa, por exigir experiência do profissional para um diagnóstico confiável (Hall e Giaccia, 2006).

Neste trabalho, busca-se facilitar a execução deste diagnóstico clínico, por meio do processamento automático de imagens obtidas por microscópios.

\subsection{Perspectiva computacional}

Diferentes tipos de técnicas têm sido propostas e relatadas, em estudos anteriores, a fim de automatizar a análise cromossômica. Seguem alguns desafios, apresentados na literatura, que frequentemente os pesquisadores encontram ao desenvolver métodos computacionais para esta tarefa: mesmo em células que não possuem cromossomos com anomalia, existem grandes variações na morfologia de um cromossomo 
para o outro (por exemplo: variações no tamanho, na posição do centrômero, na espessura das cromátides, etc.). Além disso, a disposição que o cromossomo se encontra, no momento em que é feita a aquisição da imagem, pode dificultar o reconhecimento de características que são fundamentais para a classificação (por exemplo: os braços cromossômicos podem estar dobrados de forma que não sejam visíveis na imagem bidimensional, a disposição dos braços podem propiciar a identificação de falsos centrômeros, etc.). Isso faz com que o acerto do algoritmo fique restrito às variações na morfologia do cromossomo presente na imagem que está sendo analisada. Outro problema comumente encontrado é a presença de ruídos nas imagens metafásicas, isto ocorre, entre outros motivos, devido à presença de acúmulo do corante usado durante a preparação da célula. Também é frequente se deparar com bordas cromossômicas irregulares em razão de má qualidade da imagem, ou à sobreposição de cromossomos ou à presença de cromossomos muito próximos ou conectados.

As rotinas computacionais envolvidas na análise cromossômica incluem o uso de técnicas de pré-processamento de imagens digitais, segmentação, extração de características, e o uso de técnicas de inteligência artificial para classificação dos cromossomos.

São exemplos de técnicas de pré-processamento tipicamente utilizadas em imagens cromossômicas: realce de contraste, histogramas de representação das intensidades dos pixels, aplicação de filtros entre outras modificações que visam melhorar a qualidade inicial da imagem e/ou adequá-las de forma a aumentar as chances de sucesso nas etapas seguintes.

O processo de segmentação consiste em dividir uma imagem de entrada em partes ou objetos constituintes. Um procedimento de segmentação robusto pode favorecer fortemente a solução bem sucedida de um problema que envolve o uso de imagens, entretanto, algoritmos de segmentação fracos ou erráticos quase sempre asseveram falha no processamento (Gonzalez e Woods, 1992). No caso de reconhecimento deste trabalho, o papel da segmentação é extrair os cromossomos do fundo da imagem e isolá-los em imagens independentes.

Para alguns autores, o principal desafio enfrentado refere-se aos cromossomos que se encontram sobrepostos com outros cromossomos durante a divisão celular. Nesta área destaca-se o trabalho de Somasundaram e Kumar (2014), cujo um dos objetivos é separar automaticamente estas imagens, o método proposto verifica o contorno das 
imagens binárias, a fim de identificar as "fronteiras" de um cromossomo para o outro, em seguida linhas de cortes são desenhadas na região de sobreposição e finalmente as imagens são separadas.

Em muitas aplicações, faz-se necessário o desenvolvimento de um método para que as características de interesse sejam enfatizadas. O processo de descrição, também chamado extração de características, procura selecionar características que resultem em alguma informação quantitativa de interesse ou que sejam básicas para discriminação entre classes de objetos (Gonzalez e Woods, 1992). No caso da classificação de cromossomos, um exemplo de característica importante seria a quantidade de centrômeros, já que esta informação pode auxiliar na diferenciação entre alguns tipos de cromossomos, portanto neste caso, o algoritmo deve enfatizá-la.

$\mathrm{O}$ reconhecimento e interpretação é o processo que atribui um rótulo a um objeto baseado nas informações fornecidas pela etapa de extração de características. A interpretação envolve a atribuição de significado a um conjunto de objetos reconhecidos (Gonzalez e Woods, 1992). Dentre as técnicas de inteligência artificial utilizadas para classificação dos cromossomos pode se citar: lógica Fuzzy, Redes Neurais Artificiais (RNA), algoritmos genéticos, entre outras. Seguem alguns trabalhos que se destacaram na área de classificação dos cromossomos.

O sistema desenvolvido por Keller et al. (1995) visa realizar a cariotipagem, que significa dividir os cromossomos em 7 grupos de acordo com suas características (denominados "grupos de Denver"). Para realizar a classificação, são utilizadas as seguintes informações: índice (posição) do centrômero, comprimento relativo do cromossomo, e informações relacionadas ao padrão característico de bandas, também conhecido como bandeamento cromossômico (que consiste numa técnica, onde é aplicada uma coloração especial para corar seletivamente o DNA, para que cada par cromossômico seja individualmente identificado com base no padrão característico de bandas que ele apresenta). As regras criadas neste trabalho atribuem valores de "certeza" para cromossomos normais, de forma que baixos valores indicam anomalias.

No trabalho de Souza (2011), foram desenvolvidas as funcionalidades de armazenar informações referentes a cada uma das imagens de células metafásicas em disco rígido; realizar a contagem dos cromossomos; e por meio de lógica Fuzzy, classificar as imagens cromossômicas quanto à presença de aberrações. Para a classificação são traçados 9 perfis horizontais nas imagens cromossômicas com a finalidade principal de reconhecer a 
disposição e a morfologia do cromossomo. Os padrões de perfil são baseados em duas características: o comprimento de cada banda, e a quantidade de bandas presentes em um perfil. Com base nesses perfis foi criado um conjunto de regras de inferência para a classificação dos cromossomos em normal, dicêntrico, tricêntrico e fragmentos.

No presente trabalho, antes de iniciar a etapa de classificação dos cromossomos, as imagens metafásicas são submetidas às seguintes etapas: transformação para escala de cinza, eliminação do background, ajuste de contraste, inversão de cores, rotulação, segmentação e registro. Essas transformações são realizadas de acordo com as técnicas descritas por Souza (2011), que é base para o projeto aqui proposto.

A metodologia do presente trabalho se concentra na etapa de classificação dos cromossomos e para isso utiliza um tipo de Rede Neural Artificial (RNA) denominada mapas auto-organizáveis (também conhecido por redes de Kohonen e pela sigla em inglês SOM - Self Organizing Maps). As redes de Kohonen são utilizadas em muitos projetos como ferramentas para resolver problemas multivariados de difícil solução. Seu objetivo é descobrir padrões significativos ou característicos dos dados de entrada. Essa técnica tambem é indicada para resolver problemas não-lineares de alta dimensionalidade, tais como extração de características e classificação de imagens e padrões acústicos, controle adaptativo de robôs, equalização, modulação e transmissão de sinais (Castro e Castro, 2011).

O uso dos mapas auto-organizáveis foi proposto neste trabalho porque, para se automatizar a classificação de anomalias por meio de imagens de células metafásicas, é necessário identificar padrões relacionados às morfologias dos cromossomos que permitam distinguir os tipos cromossômicos que se deseja classificar. Entretanto, esta é uma tarefa excepcionalmente complexa, dado à irregularidade na morfologia dos cromossomos, e devido a uma infinidade de variações possíveis relacionadas à disposição do cromossomo no momento em que é feita a aquisição da imagem.

Ao longo de suas experiências, o profissional citogeneticista adquire um conhecimento que o permite identificar cromossomos aberrantes mesmo em situações que sejam extremamente desfavoráveis para tal análise. Entretanto, trata-se de um conhecimento implícito, e alguns dos padrões que o permitem fazer esta distinção dificilmente serão identificados pelo programador.

Os mapas auto-organizáveis têm a capacidade de exibir um mapeamento das características de imagens mais relevantes para a classificação, e com isso podem potencialmente explicitar estes conhecimentos adquiridos implicitamente pelos 
especialistas. Isto se contrapõe a um sistema Fuzzy, por exemplo, no qual as características relevantes para a classificação precisam ser identificadas e apontadas previamente pelo programador.

Dentre as pesquisas desenvolvidas na área de reconhecimento de padrões em imagens cromossômicas utilizando-se das redes SOM, pode-se citar o trabalho de Turner et al. (1993), que desevolveu um sistema que faz estimativas de posição, comprimento e orientação do cromossomo valendo-se de imagens de baixa resolução. Este trabalho apresenta uma contribuição no que diz respeito a extração de caracteristicas em cromossomos mas não visa detectar a presença de aberrações.

Entre outros métodos que podem ser utilizados para apoiar a classificação de cromossomos, no trabalho desenvolvido por Cho (2000) uma RNA de duas camadas foi treinada utilizando-se um algoritmo de treinamento backpropagation. As características selecionadas para a classificação foram: o comprimento relativo, o índice centromérico, e características relacionadas ao bandeamento cromossômico. No entanto, o algoritmo apresentou tempo de processamento muito longo.

No trabalho de Wang et al. (2009) os algoritmos genéticos são implementados a fim de encontrar a topologia ótima para uma RNA e com isso, visam melhorar o desempenho e robustez de sistemas de cariotipagem automatizados baseado em RNA. As rotinas envolvidas no trabalho envolvem: encontrar células em metáfase, segmentar os cromossomos, detectar o eixo medial, desenhar linhas perpendiculares ao longo do eixo medial, extrair características e realizar a classificação. Neste estudo, as características selecionadas para classificação foram: distribuição de pixel, índice de centrômero, e características relacionadas ao bandeamento cromossômico. Entretanto neste sistema a classificação de cromossomos com anomalias não foi testada.

Entre os pesquisadores na área de automação da análise cromossômica se destaca Ekaterina Detcheva, da Bulgária (Detcheva, 1991, 1992, 1994, 1996, 1998). Seus esforços se concentram na aplicação de técnicas de processamento de imagens e de métodos heurísticos para o desenvolvimento do aplicativo CAIS - Chromosome Analysis Intelligent System, que realiza a análise cromossômica e classificação quanto a existência de possíveis aberrações. Outra funcionalidade do aplicativo é realizar a cariotipagem. O trabalho envolve as rotinas de pré-processamento, segmentação, extração de características e classificação. 
Uma empresa que se destaca por disponibilizar ferramentas para automatizar uma vasta área de aplicações de análise de imagens microscópicas, inclusive voltadas para a análise cromossômica é a MetaSystems ${ }^{\circledR}$ (Altlussheim, Germany). Entretanto, uma restrição apresentada está relacionada aos altos custos envolvidos, uma vez que, para se ter acesso aos softwares de análise cromossômica desenvolvidos pela empresa, é necessário a compra de todo o material envolvido, que consiste em câmera (hardware de digitalização), microscópio, e pelo menos um módulo principal Metafer ${ }^{\circledR}$ (software). Seguem dois trabalhos onde foram estudadas aplicações para os sistemas desenvolvidos pela empresa.

O trabalho de Huber et al. (2001) tem como objetivo a aplicação prática do Metafer ${ }^{\circledR}$ na análise de aberrações cromossômicas induzidas pela radiação. $\mathrm{O}$ trabalho se propõe a analisar imagens provenientes de células que foram submetidas a uma técnica citogenética denominada FISH (Fluorescence in situ hybridization). Neste trabalho são utilizados: o sistema Metafer $2^{\circledR}$; o módulo Metaphase Finder ${ }^{\circledR}$ (mSearch) - para encontrar metáfase; e o módulo Fluorescence Scanning ${ }^{\circledR}$ (MetaCyte) - para digitalizar imagens de cromossomos que foram submetidos a técnica FISH.

Em Romm et al. (2013), o objetivo é estudar a aplicação de um módulo do sistema Metafer $4^{\circledR}$, denominado Automatic Scoring of Dicentric Chromosomes ${ }^{\circledR}$ (DCScore), como ferramenta de dosimetria biológica que seja útil em caso de acidentes de radiação em larga escala, de forma que, dentre as pessoas potencialmente expostas, sejam identificados rapidamente aquelas que necessitam de tratamentos clínicos. Para isso, este módulo se concentra na identificação automática de apenas um tipo de aberração, que corresponde aos cromossomos dicêntricos. As imagens analisadas pelo DCScore são provenientes de células que foram submetidas a técnica citogenética de aberrações cromossômicas. O trabalho também inclui o uso dos seguintes módulos: Metaphase Finder $^{\circledR}$ (mSearch) - para encontrar metáfase e Automated Image Acquisition ${ }^{\circledR}$ (AutoCapt) - para captura automática de imagens de alta resolução. 


\section{OBJETIVOS E JUSTIFICATIVAS}

Monitorar os danos da radiação relacionados à saúde é extremamente importante para as populações em risco. Uma das formas mais empregadas de se fazer este monitoramento é por meio da técnica citogenética de aberrações cromossômicas. Nela, amostras de células humanas são analisadas visualmente pelo profissional citogeneticista, com o objetivo de fazer uma avaliação qualitativa e quantitativa do efeito biológico em termos de aberração cromossômica. Esta tarefa é minuciosa, pois existe um grande número de cromossomos por célula, estes apresentam tamanho pequeno, e grandes variações na aparência (morfologia). Quando realizada manualmente, os cromossomos são analisados um a um pelo profissional citogeneticista, tornando-se uma tarefa repetitiva, demorada, e de certa forma imprecisa, por exigir certa experiência do profissional para um diagnóstico confiável (Hall e Giaccia, 2006).

Com base na aplicação dos mapas auto-organizáveis, este trabalho tem como objetivo o desenvolvimento de um sistema automatizado de classificação cromossômica que auxilie no monitoramento dos danos associados à radiação.

Dentre as etapas que envolvem a automação da análise cromossômica, esta dissertação concentra-se no desenvolvimento de uma metodologia de extração de características e classificação cromossômica, capaz de classificar os cromossomos em: anel, dicêntrico, e normal.

O desenvolvimento desta metodologia consiste no estudo sistemático das características mais importantes das imagens digitais dos cromossomos para a classificação proposta, e implica no desenvolvimento de métodos que buscam a extração eficiente destas características que produzam otimização no desempenho da neural de Kohonen para este objetivo. 


\section{FUNDAMENTAÇÃO TEÓRICA}

Esta seção descreve alguns fundamentos teóricos sobre as radiações ionizantes, os seus efeitos biológicos, a análise cromossômica, algumas técnicas de processamento de imagens utilizadas em sistemas que visam automatizar essa análise, e por fim, sobre as redes neurais artificiais, com foco nos mapas auto-organizáveis.

\section{1 Considerações gerais sobre a radiação ionizante}

O termo radiação significa propagação de energia sob a forma de ondas eletromagnéticas, ou sob a forma de partículas, sejam elas com ou sem carga.

A radiação eletromagnética se caracteriza pela oscilação de um campo elétrico e um campo magnético, que se geram mutuamente e se deslocam perpendicularmente um em relação ao outro e em relação à direção de propagação da energia. Ela pode ser classificada de acordo com a frequência desta oscilação, e, dependendo da faixa de frequência, recebe diferentes denominações: ondas de rádio, de TV, microondas, radiação infravermelha, luz visível, radiação ultravioleta, raios $\mathrm{X}$ e raios gama.

Já a radiação corpuscular é constituída por um feixe energético de partículas, como por exemplo: elétrons, prótons, nêutrons, pósitrons, dêuterons e partículas alfa e beta (Okuno, 1988).

A interação da radiação (seja eletromagnética ou corpuscular) com a matéria resulta na transferência de energia para os átomos ou moléculas que estiverem na sua trajetória. Com isso, a radiação pode ocasionar a elevação do átomo a uma camada orbital mais energética (saindo portanto do nível energético fundamental) sendo esse fenômeno conhecido como excitação.

Outro fenômeno ocorre quando a transferência de energia é suficientemente alta para arrancar elétrons orbitais de átomos ou moléculas do meio onde se propaga, produzindo pares de íons, ocorrendo a ionização. Neste caso a radiação é dita ionizante.

\section{2 Efeitos biológicos da radiação}

$\mathrm{Na}$ absorção da radiação ionizante por um material biológico, existe a possibilidade de que a radiação venha a interagir com macromoléculas biologicamente 
importantes das células, particularmente o DNA, que é considerado o principal alvo da radiação, já que é responsável pela codificação da estrutura de todas as proteínas da célula, e portanto a molécula chave no processo de estabelecimento de danos biológicos (Nouailhetas, 2000; Hall e Giaccia, 2006).

De acordo com Okuno (1988, p.45) as consequências da exposição da célula à radiação podem ser resumidas em quatro tipos de eventos: a radiação passa próximo ou através da célula sem produzir dano; a radiação danifica a célula, mas ela é reparada adequadamente; a radiação mata a célula ou a torna incapaz de se reproduzir; o núcleo da célula é lesado, sem, no entanto, provocar morte celular. A célula sobrevive e se reproduz na sua forma modificada, podendo ocorrer basicamente dois tipos de danos: as mutações gênicas e as quebras de moléculas no DNA, que serão descritas adiante.

As mutações podem ser acumuladas sem que as células manifestem qualquer efeito. Isto acontece porque nem todas as moléculas de DNA codificam genes ativos em um tipo particular de célula. Isso significa que, no caso de exposição às radiações, a probabilidade de que genes funcionais tenham sua estrutura alterada é relativamente pequena. (Nouailhetas, 2000).

Nos casos de células que apresentam mutações em genes funcionais, existe a possibilidade de que elas sejam acumuladas em tecidos ou órgãos sem prejuízo significativo para o indivíduo irradiado. Isto porque a contribuição de uma única célula para o desempenho de um órgão ou tecido é insignificante perante o total de células que o integram.

As quebras de moléculas do DNA não reparadas resultam na perda da integridade física do material genético, e prejudicam o processo de divisão celular, impedindo que as células transfiram seu patrimônio genético e, consequentemente, se reproduzam. Caso haja o rearranjo dos fragmentos resultantes das quebras de DNA, pode ocorrer o surgimento de cromossomos modificados em relação a estrutura original, ou seja, aberrantes. Por sua vez, células contendo cromossomos aberrantes podem se duplicar dando origem a uma população de células anormais (Nouailhetas, 2000).

\subsubsection{Amplitude do dano}

A amplitude do dano biológico vai depender, entre outros fatores, essencialmente do tipo de radiação, da dose aplicada e do tipo celular. 
Os diferentes tipos de radiação ionizante induzem danos biológicos qualitativamente similares porém não quantitativamente, isso porque os efeitos biológicos estão relacionados com o conceito de transferência linear de energia ("Linear Energy Transfer" ou LET), um parâmetro que define a quantidade de energia média depositada na matéria por unidade de distância percorrida $(\mathrm{keV} / \mu \mathrm{m})$. O valor do LET varia com a velocidade, massa e carga da radiação ionizante. De modo geral, as radiações de alto LET, tais como nêutrons, partículas $\alpha$ e fragmentos de fissão, produzem maior dano biológico que as radiações de baixo LET, como os raios X, partículas $\beta$ e radiação $\Upsilon$ (Hall e Giaccia, 2006; Da Silva, 2001).

Existem dois principais tipos de mecanismos pelos quais a radiação pode lesar uma molécula: o direto e o indireto. No mecanismo direto a radiação age diretamente sobre uma biomolécula, danificando o material genético, esse é o processo dominante para radiações com alto LET. Por outro lado, a ação indireta da radiação é um mecanismo dominante para radiações de baixo LET. Neste caso moléculas como a da água são quebradas pela radiação. Seus produtos, o radical livre hidroxila $\mathrm{OH}^{-}$e o produto oxidante peróxido de hidrogênio, podem produzir dano biológico ao atacar biomoléculas importantes da célula (Okuno, 1988; Da Silva, 2001).

Quanto maior a dose absorvida, menor é o intervalo de tempo entre a exposição e o aparecimento do efeito. Os efeitos biológicos da radiação são comumente classificados em somáticos e hereditários. Os efeitos somáticos afetam a pessoa irradiada, enquanto que os efeitos hereditários, os descendentes da pessoa irradiada. Os efeitos somáticos podem ainda ser divididos em agudos (ou a curto prazo) e tardios (ou a longo prazo), dependendo do tempo de manifestação dos efeitos que depende da dose absorvida (Okuno, 1988).

O estágio do desenvolvimento no qual o organismo se encontra no momento da exposição repercute nas consequências das mutações em genes. Por exemplo: mutações na célula-ovo podem inviabilizar seu desenvolvimento; na fase embrionária, podem resultar em má formação de tecido, órgãos e membros. Caso as mutações ocorram na linhagem de células produtoras de gametas, é possível a transferência de mutações do indivíduo irradiado para sua descendência (Nouailhetas, 2000).

Isto ocorre porque as células apresentam diferentes sensibilidades aos efeitos somáticos da radiação ionizante, dependendo do tipo e da fase de seu ciclo de reprodução. Células em divisão, ou as que são metabolicamente ativas, ou, ainda, as que se reproduzem rapidamente, tais como as células brancas do sangue, são mais sensíveis que aquelas 
altamente diferenciadas, como as do músculo, osso e tecido nervoso. De um modo geral, quanto mais jovem o indivíduo, mais sensível ele é a radiação (Okuno, 1988).

\subsubsection{Câncer radioinduzido}

As mutações no genoma são o primeiro passo, entre diversos outros, que contribuem para o processo de desenvolvimento do câncer, o que faz com que o período entre o momento em que ocorrem mutações no genoma de uma célula e a eventual manifestação do câncer possa ser de vários anos, senão de décadas. Desta forma, a probabilidade de cancerização com base em células irradiadas é superior à probabilidade de ocorrência deste processo com base em células não irradiadas. Pois quanto maior a quantidade de dose de radiação absorvida por um indivíduo, maior a probabilidade de que venha a desenvolver a doença (Nouailhetas, 2000).

Na Figura 1 é mostrada uma curva dose-resposta para aberrações produzidas por raios Gama em linfócitos humanos. Quando amostras de sangue são obtidas para avaliação citogenética dentro de alguns dias a algumas semanas após a irradiação de corpo inteiro, a frequência de aberrações assimétricas nos linfócitos (dicêntricos e anéis) reflete a dose recebida. No gráfico o componente linear ocorre quando as células são submetidas a baixa dose de radiação. Enquanto que se tratando de doses mais elevadas, a ocorrência de aberração é proporcional ao quadrado da dose (Hall e Giaccia, 2006).

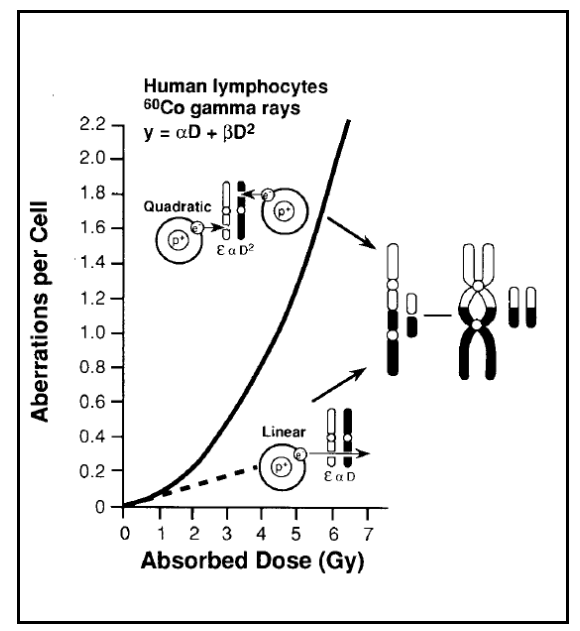

FIGURA 1 - Curva dose-resposta para a aberração em linfócitos humanos produzidos por raios Gama (Hall e Giaccia, 2006)

No entanto, é importante ressaltar duas informações: nem todas as mutações radioinduzidas evoluem obrigatoriamente para câncer, e nem todas as mutações se manifestam em virtude da ação das radiações ionizantes (que é o enfoque deste trabalho), 
as mutações também podem ocorrer de forma espontânea, ou serem induzidas por outros agentes genotóxicos.

\subsubsection{Aberrações cromossômicas}

As aberrações cromossômicas são consideradas indicadores biológicos sensíveis ao dano ocorrido no ácido desoxirribonucleico (DNA) (Da Silva, 2001). Para melhor compreensão, faz-se necessário uma breve revisão teórica.

Os genes são unidades de informação genética distribuídos em locais exatos, na molécula de DNA que está compactada e armazenada em estruturas filamentares denominadas cromossomos, que estão presentes no interior do núcleo celular (Nussbaum et al., 2004).

Um indivíduo recebe um conjunto de 23 cromossomos do pai que fará par com o conjunto de 23 cromossomos da mãe, formando pares de cromossomos que são chamados de cromossomos homólogos, ou seja, cada cromossomo do par tem informação para o mesmo grupo de características. Portanto, uma célula humana típica possui 46 cromossomos. De modo que, o número de cromossomos é constante dentro de uma mesma espécie. Os genes existentes, em cada cromossomo, que carregam informações para a mesma característica são designados por genes alelos. Estes estão situados no mesmo local relativo dos cromossomos homólogos.

Assim, qualquer alteração na sequência dos genes, ou no número de cromossomos na célula resulta em anomalias que recebem o nome de aberrações cromossômicas. Essas aberrações podem causar desequilíbrio na formação, no desenvolvimento, no crescimento e no metabolismo das células.

As células passam por um ciclo que compreende dois períodos fundamentais: a interfase, onde ocorre a síntese e a duplicação do DNA e de todas as outras substâncias e estruturas da célula; e a divisão celular, onde ocorre a mitose ou a meiose.

A meiose ocorre com a finalidade específica de produzirmos as células sexuais ou gametas (espermatozoide e óvulo). Nela a célula mãe se divide formando quatro células com metade do número de cromossomos $(\mathrm{n}=23)$.

A mitose é um processo onde ocorre a formação de duas células-filhas diploides $(n=46)$ idênticas à célula-mãe, que originou todo o processo. Ela compreende uma série de fases consecutivas, são elas: prófase, metáfase, anáfase e telófase. Na Figura 2 são apresentadas as fases da divisão mitótica. 
Na metáfase os cromossomos estão mais facilmente visíveis, e portanto é nessa etapa que geralmente é realizada a análise morfológica do cromossomo a fim de detectar uma possível aberração. Para isso, usa-se a colchicina, que inibe a formação do fuso mitótico na metáfase, na presença dessa droga, a mitose ocorre normalmente, mas é interrompida na metáfase.

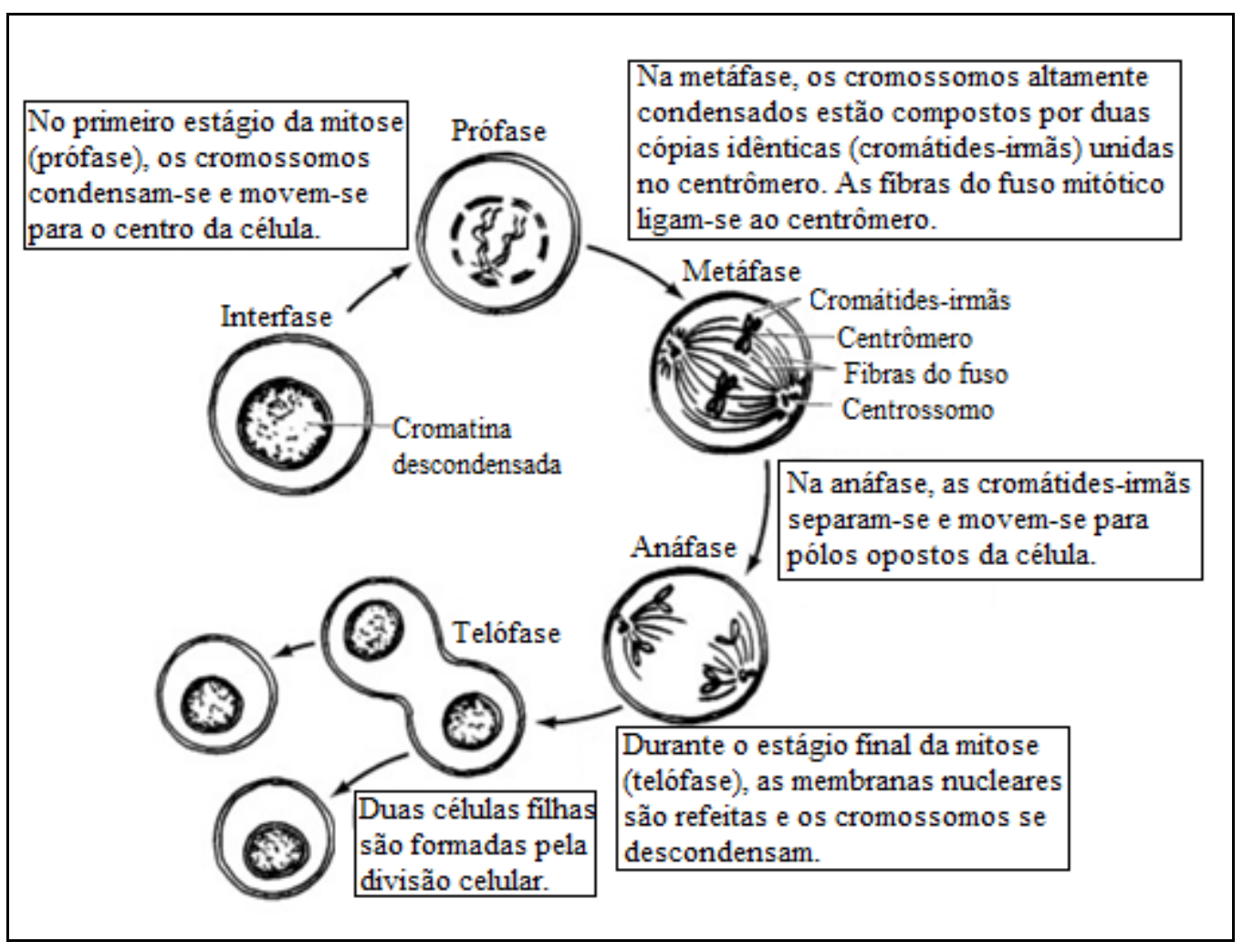

FIGURA 2 - Fases da divisão mitótica (Cooper e Hausman, 2007)

Durante a metáfase o cromossomo é formado por duas metades cromossômicas, denominadas cromátides irmãs, que se encontram presas por uma região chamada centrômero. Na Figura 3 é apresentada a estrutura do cromossomo durante esta etapa. 


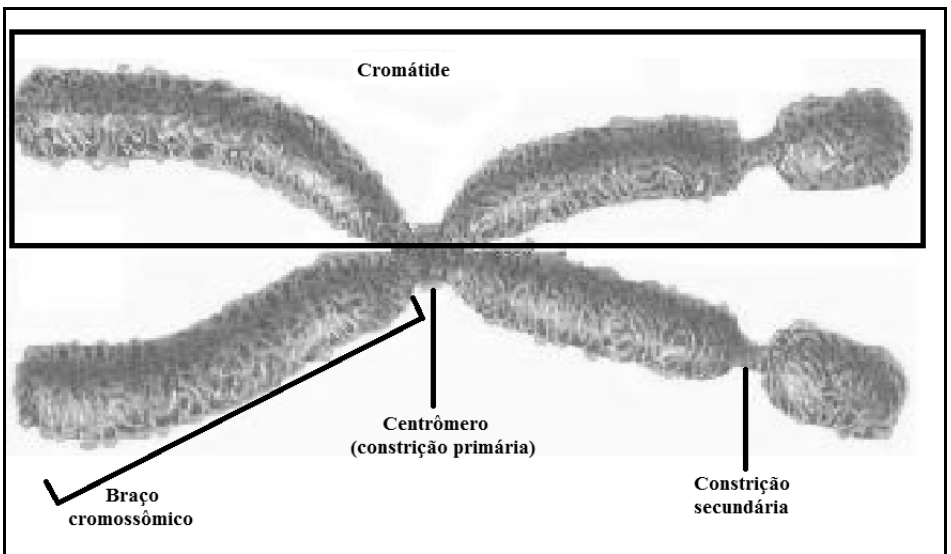

FIGURA 3 - Estrutura do cromossomo metafásico (Lemm, 2012)

Morfologicamente os cromossomos são classificados de acordo com o posicionamento do centrômero, em 4 tipos diferentes: metacêntrico - quando o centrômero está localizado exatamente no meio do cromossomo; submetacêntrico - quando ele está "um pouco" afastado do centro (e, em cada cromátide, os braços têm tamanhos diferentes); acrocêntrico - quando o centrômero está mais próximo das extremidades do que do centro (mas não nas extremidades de uma cromátide); telocêntrico - quando ele está numa das extremidades do cromossomo. É importante ressaltar que na espécie humana, não há ocorrência de telocêntricos. O centrômero divide o cromossomo em dois braços: o braço curto, designado pela letra 'p' e o braço longo, por 'q', conforme mostrado na Figura 4.

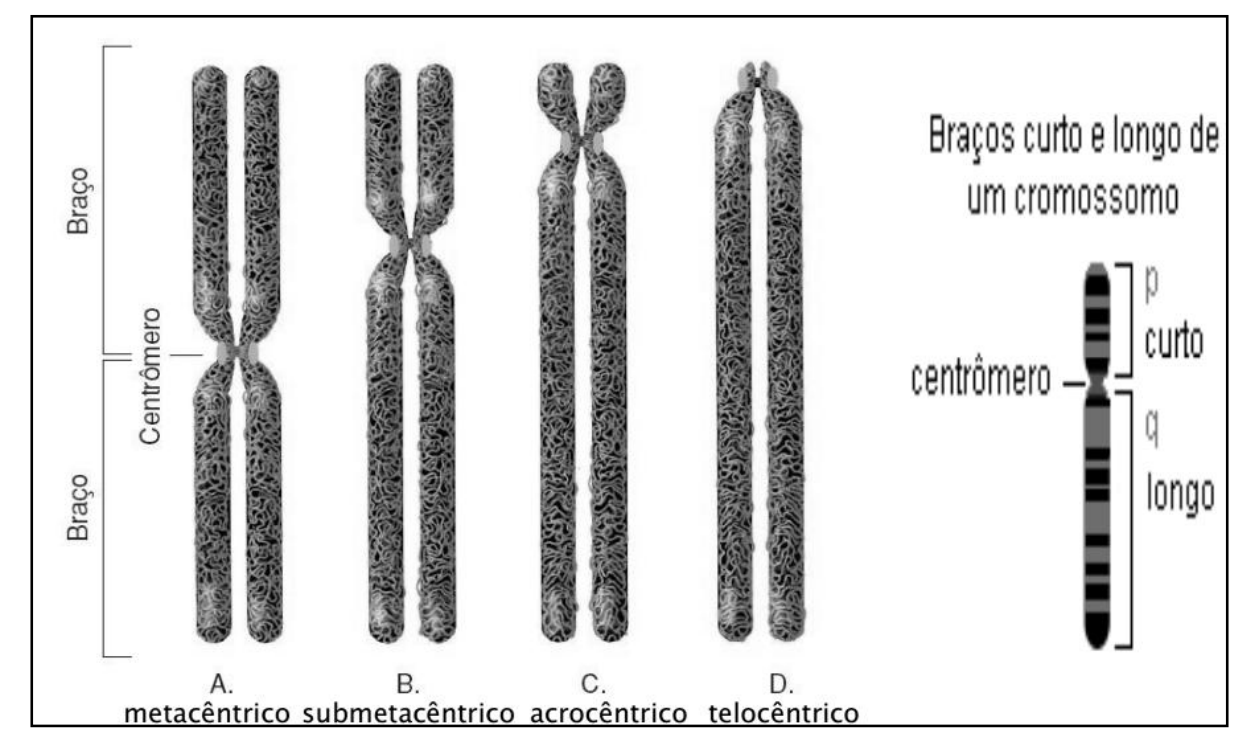

FIGURA 4 - Tipos de cromossomos: A) metacêntrico, B) submetacêntrico, C) acrocêntrico, D) telocêntrico (Lemm, 2012) 
A gravidade das manifestações de uma deficiência decorrente das aberrações cromossômicas está diretamente relacionada com os genes envolvidos. Dentre as consequências pode-se citar retardo mental, déficit pondero-estatural, dismorfismo facial e malformação congênita, tal como: cardiopatia congênita, anomalia esquelética e acometimento de outros órgãos internos (Vasconcelos, 2007).

Quando as aberrações relacionam-se com alterações no número ou no arranjo dos genes no cromossomo, em grande parte dos casos ocasionando alterações na morfologia do cromossomo, elas são denominadas mutações estruturais, já quando relacionam-se com um aumento ou diminuição do número cromossômico do genoma são chamadas de mutações numéricas.

\subsubsection{Aberrações numéricas dos cromossomos}

Estão divididas em aneuploidias, e euploidias. As aneuploidias ocorrem quando há o ganho ou perda de um ou mais cromossomos. Nas aneuploidias, as perdas ou ganhos de cromossomos relacionam-se às anormalidades ocorridas durante a formação dos gametas dos pais.

Já a euploidia é a perda de todo um conjunto de genoma, originando um indivíduo haplóide (n), ou o acréscimo de um genoma, ou mais, dando um indivíduo triplóide (3n), tetraplóide (4n), ou poliplóide quando há vários genomas em excesso.

\subsubsection{Aberrações estruturais dos cromossomos}

O ciclo das células animais compreende o período de interfase, subdividido nas fases G1, S e G2, seguido de um período divisional. Dependendo da fase do ciclo celular em que se encontra no momento da irradiação, as mudanças estruturais podem envolver apenas uma das cromátides (tipo cromatídico) ou ambas as cromátides (tipo cromossômico), conforme apresentado na Figura 5. 


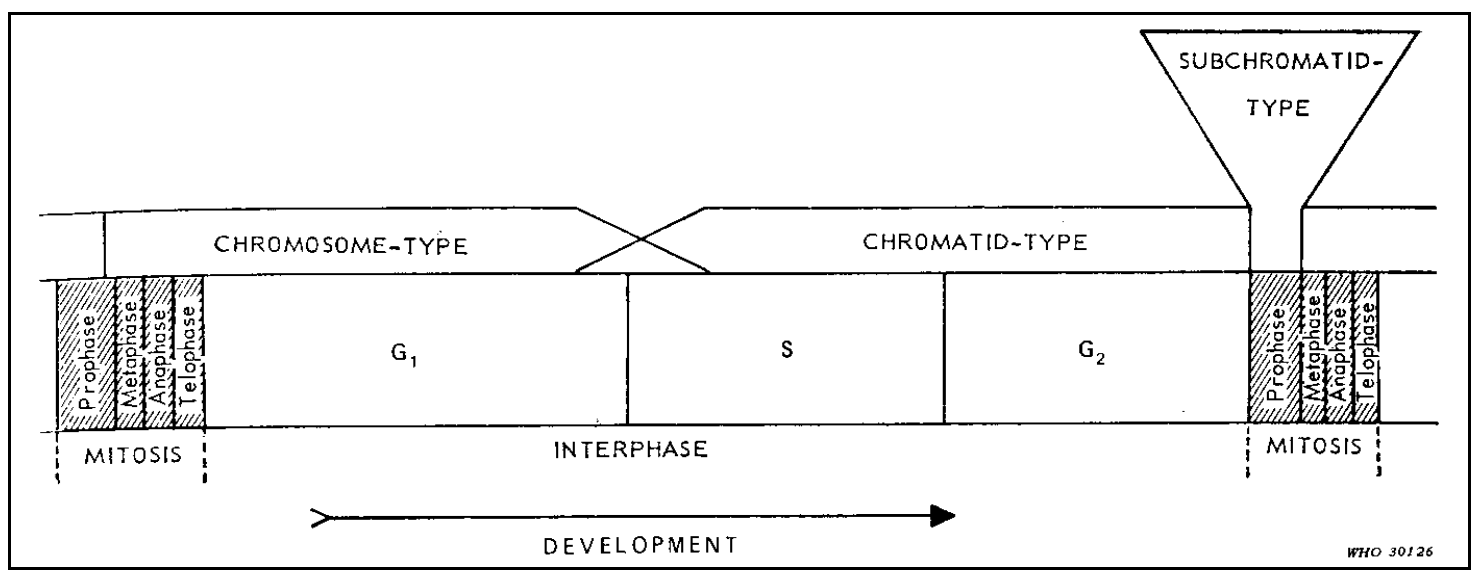

FIGURA 5 - Relação entre o tipo de aberração e o estágio no ciclo celular no momento da irradiação (Buckton e Evans, 1973)

A irradiação das células na fase G1 resulta na produção de aberrações do tipo cromossômico. Existe uma transição do tipo cromossômico para o tipo cromatídico no final da G1 e no início da $\mathrm{S}$. No entanto a maioria das células irradiadas enquanto em $\mathrm{S}$ e todas as células irradiadas enquanto na G2 produzem aberrações do tipo cromatídico.

Além disso, as mudanças estruturais podem envolver troca igual de material entre as duas zonas de cromossomos (equilibrado) ou pode ser não recíproca, de tal modo que porções do genoma são perdidas ou adquiridas.

\subsubsection{Aberração do tipo cromossômico}

De acordo com Buckton e Evans (1973, p.19), sete tipos de aberrações podem ser citologicamente distinguidas. Essas aberrações são mostradas na Figura 6 e posteriormente descritas. 


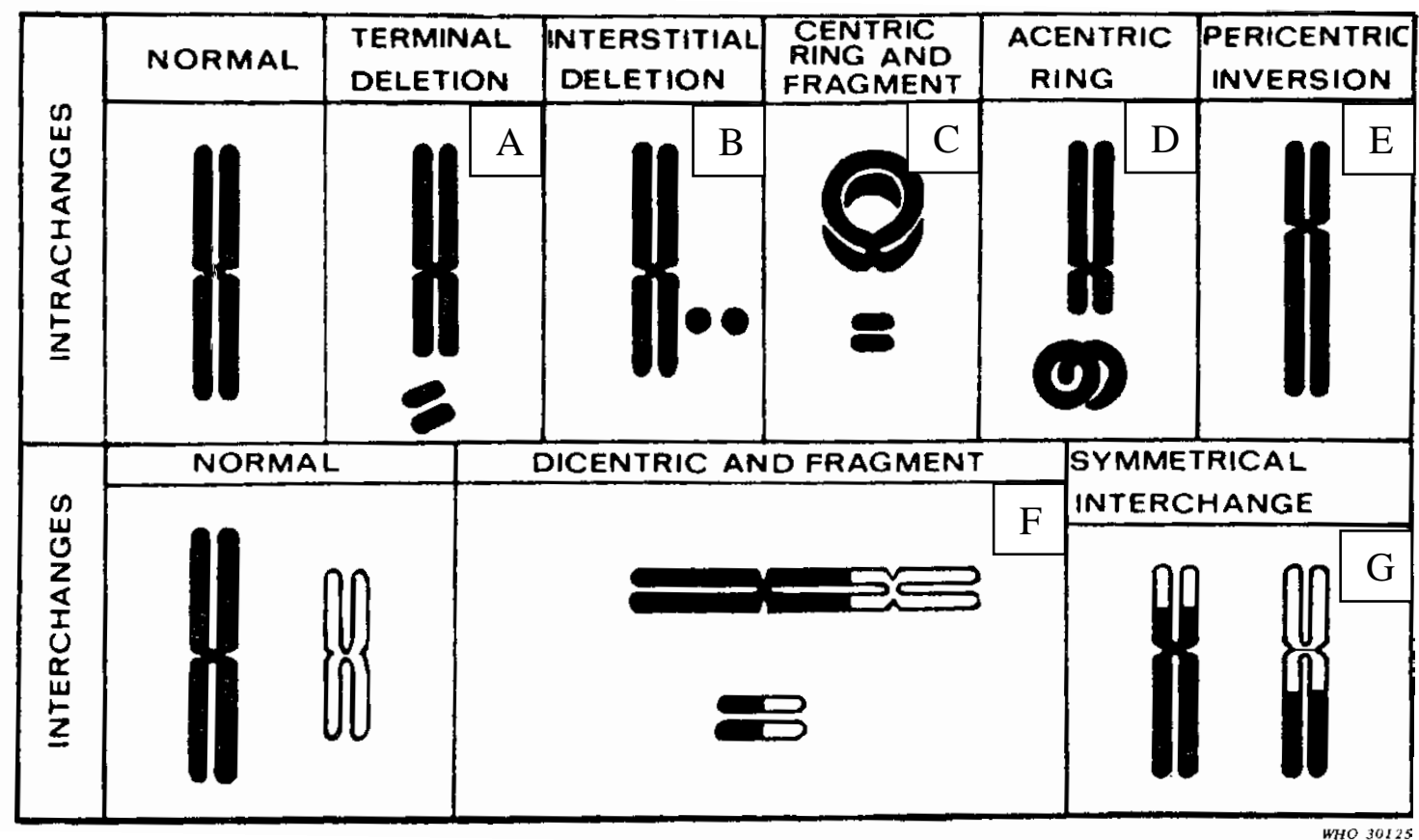

FIGURA 6 - Aberrações do tipo cromossômico na mitose (Adaptado de Buckton e Evans, 1973)

A) Deleção terminal (fragmentos acêntricos): neste tipo de aberração o cromossomo perde fragmentos de ambas as cromátides. Esses fragmentos se encontram paralelos um ao outro, mas não existe qualquer centrômero, conforme apresentado na Figura 7.

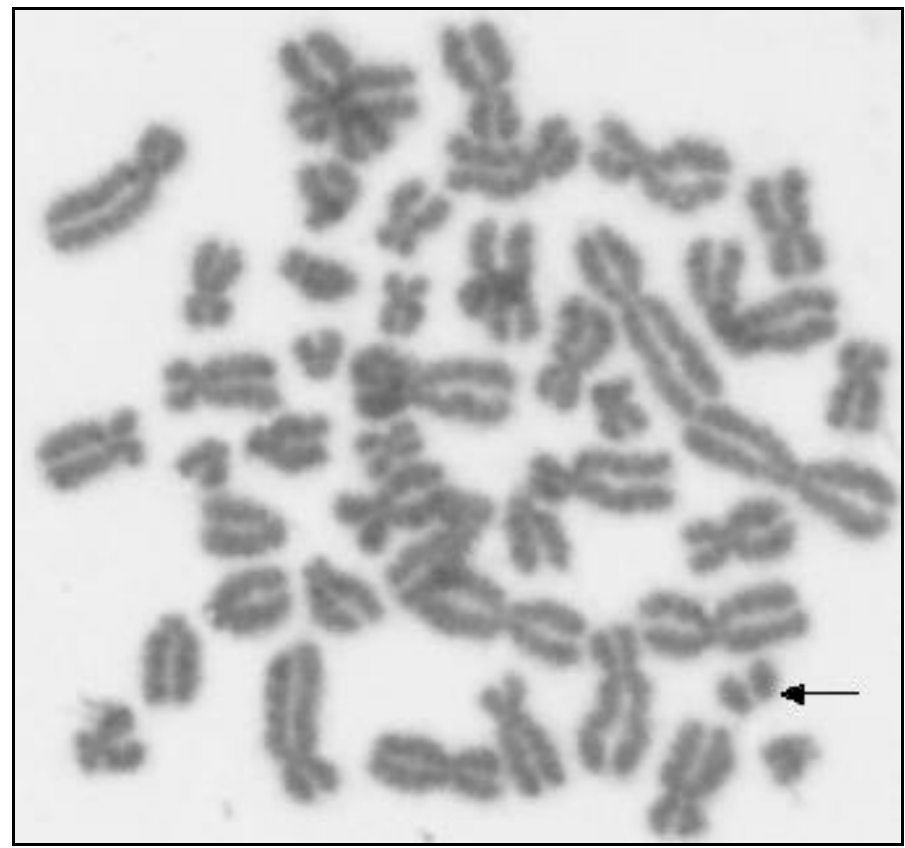

FIGURA 7 - Célula humana metafásica que apresenta uma ocorrência de fragmentos acêntricos (Cedida pela equipe do Centro de Biotecnologia IPEN/CNEN) 
B) Deleção intersticial (double minute, minutos, isodiamétrico, ou deleção pontual): resulta de duas quebras ocorridas no mesmo braço cromossômico, onde a primeira extremidade que se desprendeu, se une ao restante do cromossomo, ficando a extremidade intermediaria sozinha, dando origem a um fragmento acêntrico, conforme apresentado na Figura 8.

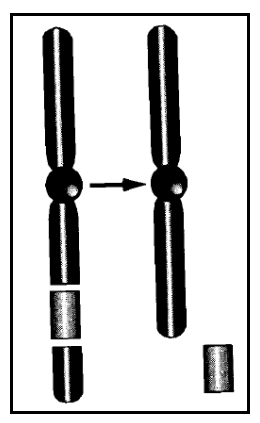

FIGURA 8 - Deleção intersticial antes da replicação celular (Hall e Giaccia, 2006)

Após a replicação celular são originados pareamentos de fragmentos cromatídicos, menores em tamanho que os fragmentos acêntricos, caracteristicamente aparecendo como esferas, daí os termos deleções 'pontuais' ou 'isodiamétricas', na Figura 9 são apresentadas duas ocorrências desse tipo de aberração.

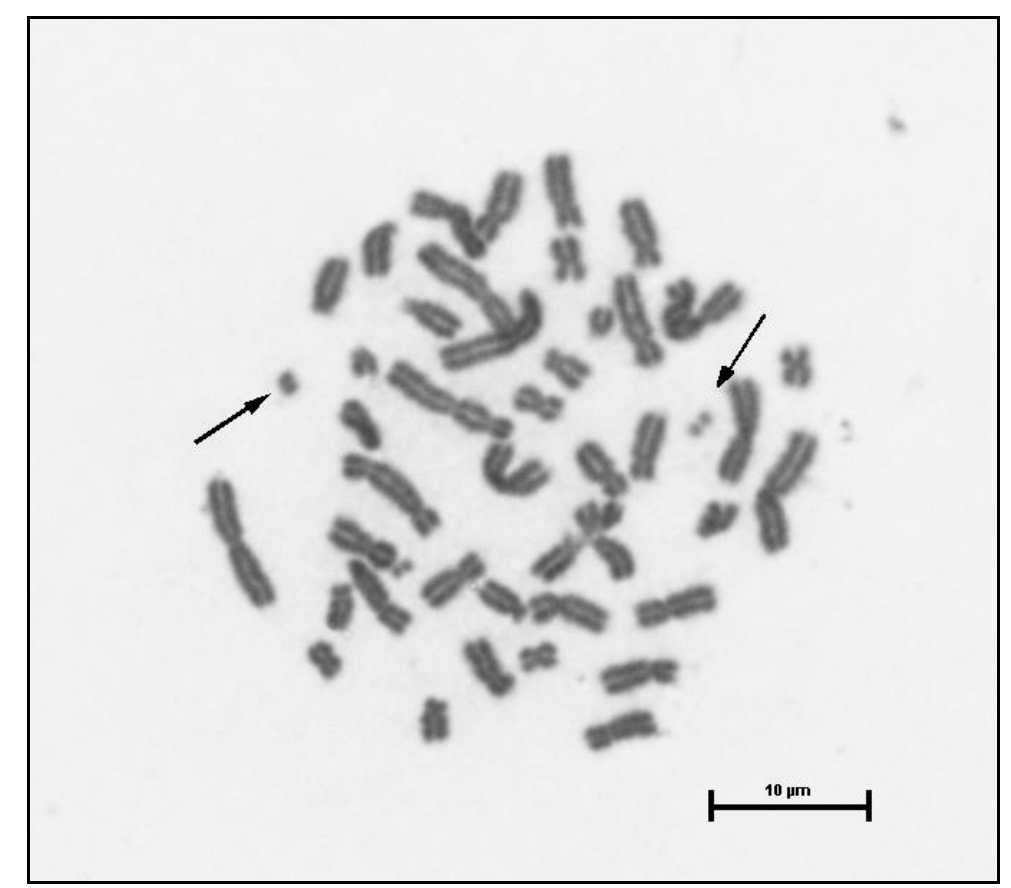

FIGURA 9 - Célula humana metafásica que apresenta duas ocorrências de deleção pontual (Cedida pela equipe do Centro de Biotecnologia IPEN/CNEN) 
C) Anéis cêntricos: cromátides são emparelhadas com a forma de um anel no qual há um centrômero. Na Figura 10 é ilustrada a sequência de passos para formação de anéis cêntricos.

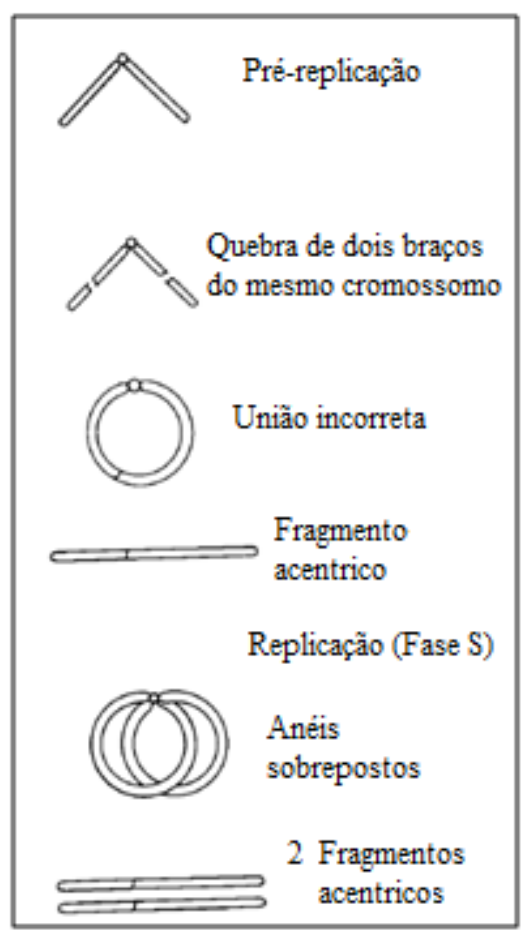

FIGURA 10 - Passos para a formação de um cromossomo em anel cêntrico (Adaptado de Hall e Giaccia, 2006)

Inicialmente quebras ocorrem em ambos os braços do mesmo cromossomo. Posteriormente as extremidades se unem de forma incorreta formando um anel e um fragmento acêntrico. Em seguida ocorre a replicação resultando em dois círculos ligados pelo centrômero. Na Figura 11 é mostrado uma ocorrência de um anel cêntrico em uma célula humana metafásica. 


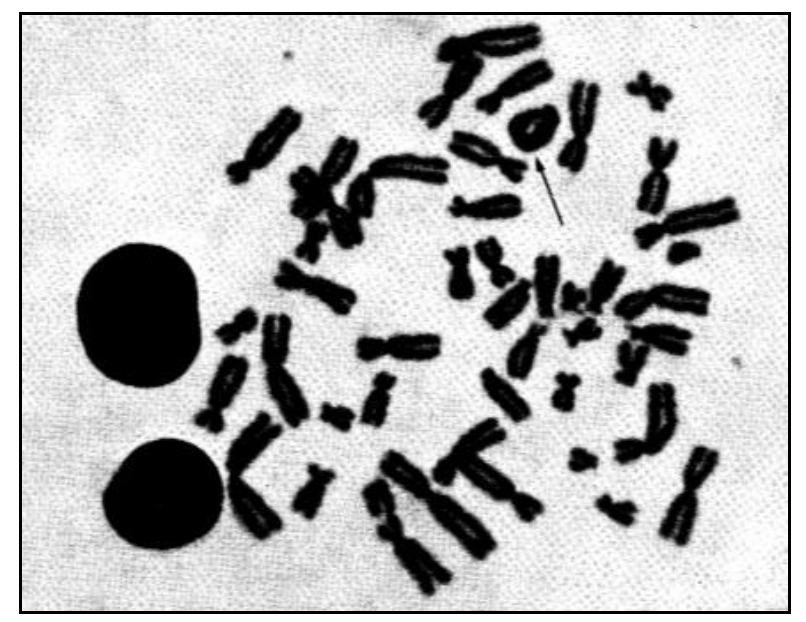

FIGURA 11 - Célula humana metafásica que apresenta uma ocorrência de cromossomo em anel cêntrico (Buckton e Evans, 1973)

D) Anéis acêntricos: cromátides são emparelhadas na forma de um anel no qual não há centrômero, conforme apresentado na Figura 12.

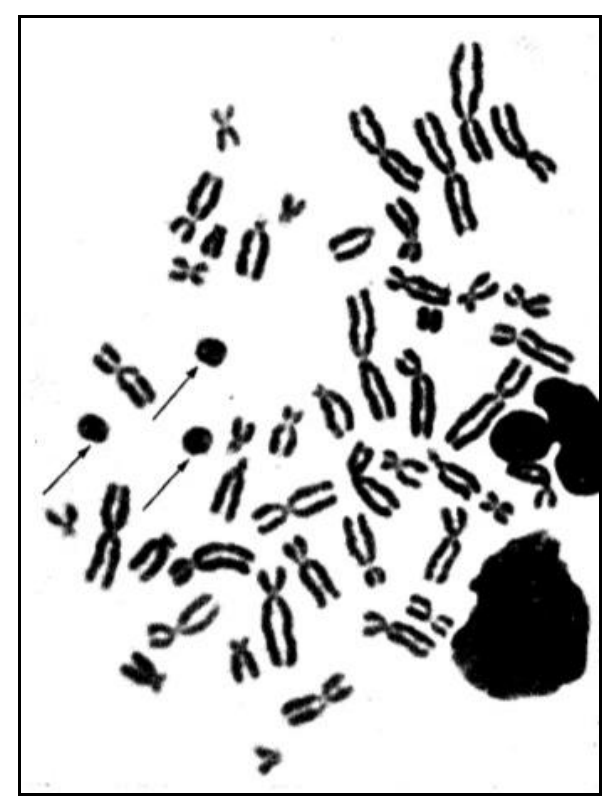

FIGURA 12 - Célula humana metafásica que apresenta três ocorrências de cromossomos em anel acêntricos (Buckton e Evans, 1973).

E) Inversões pericêntricas: são o resultado de duas quebras no mesmo cromossomo, seguido da inversão do segmento centromérico e sua reincorporação no cromossomo, conforme apresentado na Figura 13. 


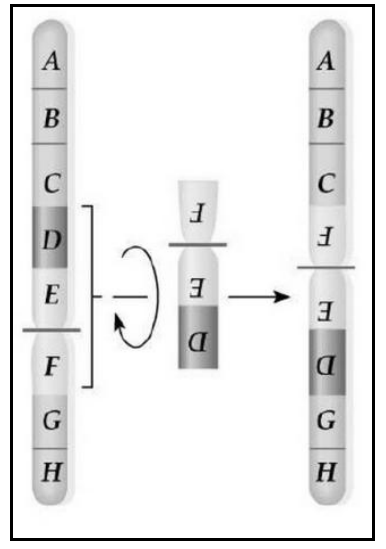

FIGURA 13 - Ilustração da formação de uma inversão pericêntrica (Pereira, 2010)

F) Dicêntricos (translocações assimétricas ou policêntricas mais complexas): são aberrações por causa de trocas entre dois ou mais cromossomos. Na Figura 14 é mostrado o passo a passo da formação desse tipo de aberração.

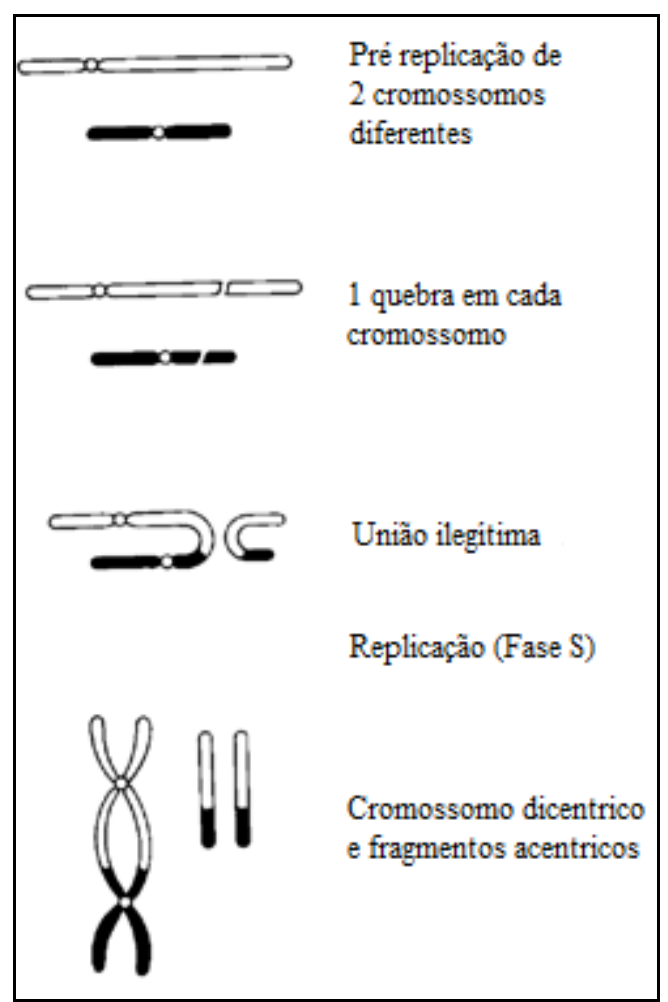

FIGURA 14 - Passos para a formação de um cromossomo dicêntrico (Adaptado de Hall e Giaccia, 2006)

No caso da estrutura dicêntrica ocorre uma troca interna entre dois cromossomos diferentes. Uma quebra é produzida em cada um dos cromossomos no início da interfase, como as extremidades coesivas estão próximas uma da outra, formam-se uniões invertidas, havendo assim, troca de material genético. Esta aberração vai se replicar durante a síntese do DNA, e o resultado será um cromossomo grosseiramente distorcido 
com dois centrômeros (dicêntricos). Haverá também um fragmento que não tem nenhum centrômero (fragmento acêntrico). Um exemplo de um cromossomo dicêntrico é mostrado na Figura 15.

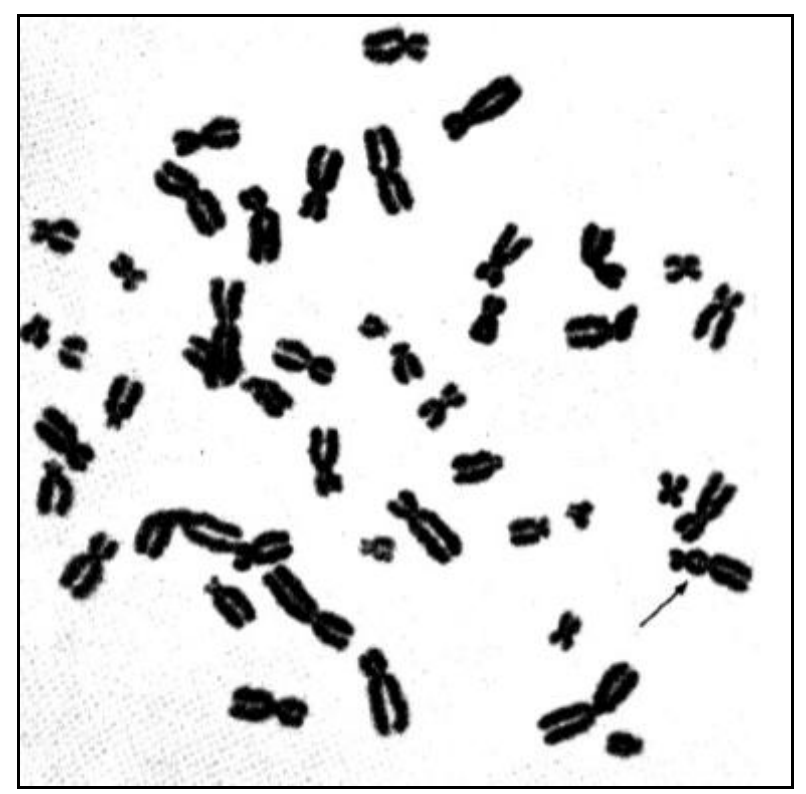

FIGURA 15 - Célula humana metafásica que apresenta uma translocação assimétrica dicêntrica (Buckton e Evans, 1973)

G) Translocações simétricas (translocação recíproca): são aberrações resultantes de uma troca entre dois cromossomos de tal forma que a região periférica dos dois cromossomos é transferida (translocada) de um para o outro. Na Figura 16 é mostrado esse tipo de aberração.

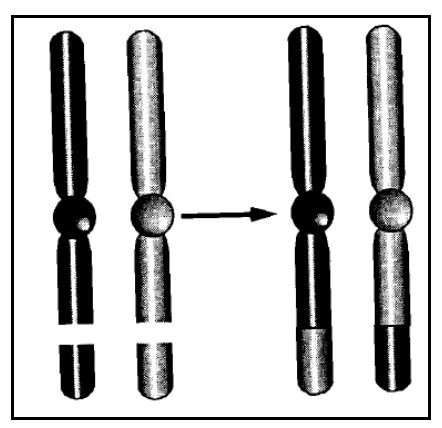

FIGURA 16 - Ilustração da formação de uma translocação simétrica (Hall e Giaccia, 2006)

As aberrações cromossômicas estruturais também podem ser classificadas como instáveis ou estáveis. As aberrações estáveis são aquelas que não causam dificuldades na divisão celular e dessa maneira podem se perpetuar por várias gerações. São exemplos de aberrações estáveis: translocações simétricas e inversões. 
Já as aberrações instáveis podem ser eliminadas seletivamente da população de células proliferativas. São exemplos de aberrações instáveis: deleção terminal, dicêntricos, minutos, anéis cêntricos e acêntricos.

\subsubsection{Aberrações do tipo cromatídico}

Quando as mudanças estruturais envolvem apenas uma das cromátides podem ocorrer quebras ou lacunas.

A) Quebra cromatídica: geralmente, quebras cromatídicas e trocas cromatídicas podem ser induzidas por radiação nas fases S e G2 do ciclo celular, quando o cromossomo se dividiu em duas cromátides. Entretanto, sob certas condições a radiação pode causar o tipo cromatídico de aberração mesmo quando emitidas na fase G1, por exemplo, antes da replicação da estrutura cromossômica. Podem ser utilizadas como indicadores de dose em colônias de células proliferando normalmente, embora a quantidade produzida desse tipo de aberração em qualquer nível de dose dada é muito dependente da fase de desenvolvimento exata da célula no momento da exposição. Na Figura 17 é mostrado uma um exemplo de quebra cromatídica.

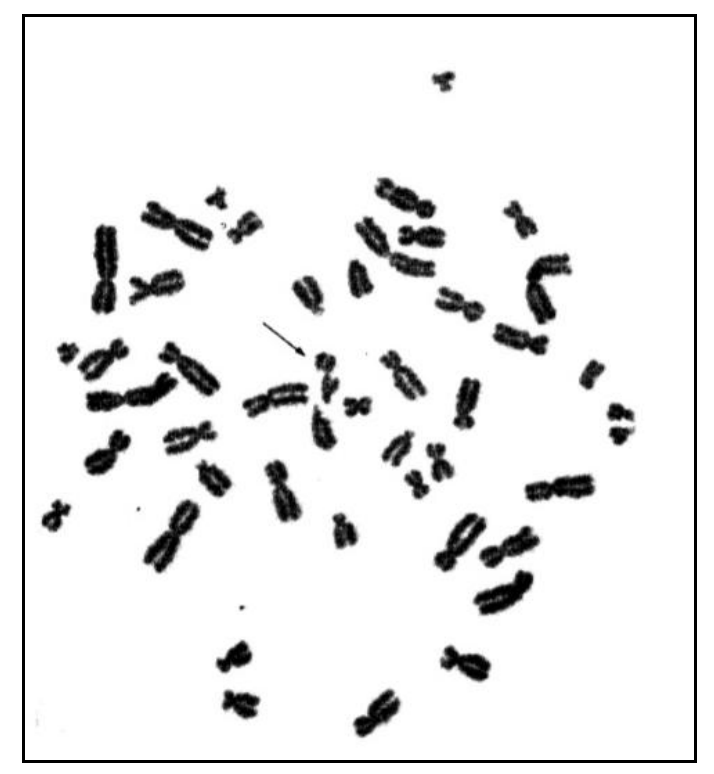

FIGURA 17 - Célula humana metafásica que apresenta uma quebra cromatídica (Buckton e Evans, 1973)

B) Lacunas: podem aparecer em uma ou ambas as cromátides, revelando uma diferença de comprimento ou de diâmetro, e são classificadas como falhas individuais. Em contraste com as quebras de cromátides, lacunas não produzem fragmentos acêntricos quando seguem através da anáfase. Por isso, elas não podem ser consideradas como verdadeiras 
descontinuidades da estrutura dos cromossomas. Na Figura 18 é apresentado um exemplo de lacuna.

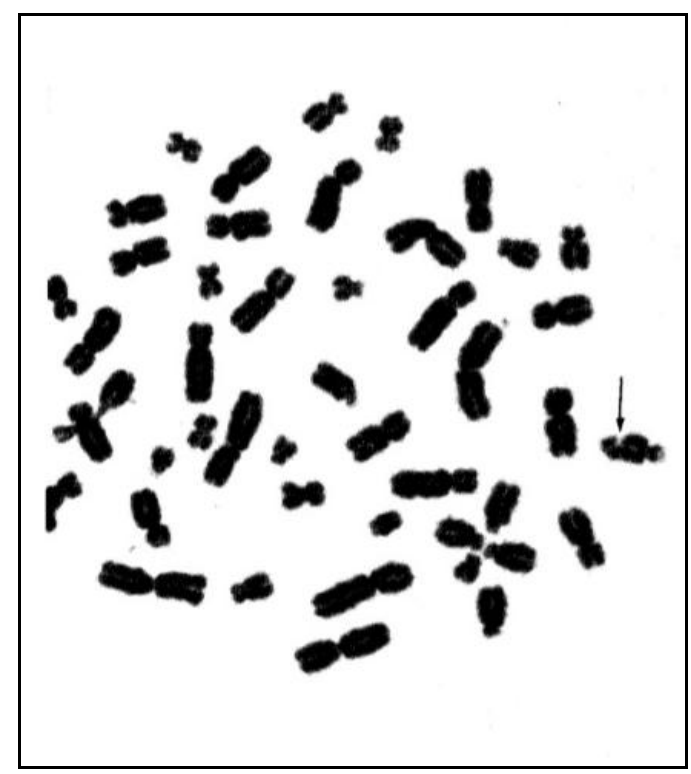

FIGURA 18 - Cariótipo que apresenta lacuna cromatídica (Buckton e Evans, 1973)

A maioria das lacunas de cromátides observadas em culturas de células do sangue periférico é causada por artefatos técnicos. A quantidade produzida é extremamente variável, lacunas, portanto, não são bons indicadores quantitativos de dose de radiação (Buckton e Evans, 1973).

\subsection{Considerações gerais sobre técnicas de análise cromossômica}

Com o desenvolvimento de inúmeras técnicas citogenéticas veio a necessidade de se atualizar e unificar a nomenclatura cromossômica, com este objetivo desde 1963, uma série de documentos conhecidos sob a sigla ISCN (International System for Human Cytogenetic Nomenclature) vem sendo desenvolvida (Shaffer et al., 2013). Os pares de autossomos são numerados de 1 a 22 em ordem decrescente de tamanho e os cromossomos sexuais recebem a notação $\mathrm{X}$ e $\mathrm{Y}$. Os pares cromossômicos, incluindo os sexuais, são reunidos em sete grupos designados pelas letras A até G. Conforme o cariograma de cromossomos humanos apresentado na Figura 19. 


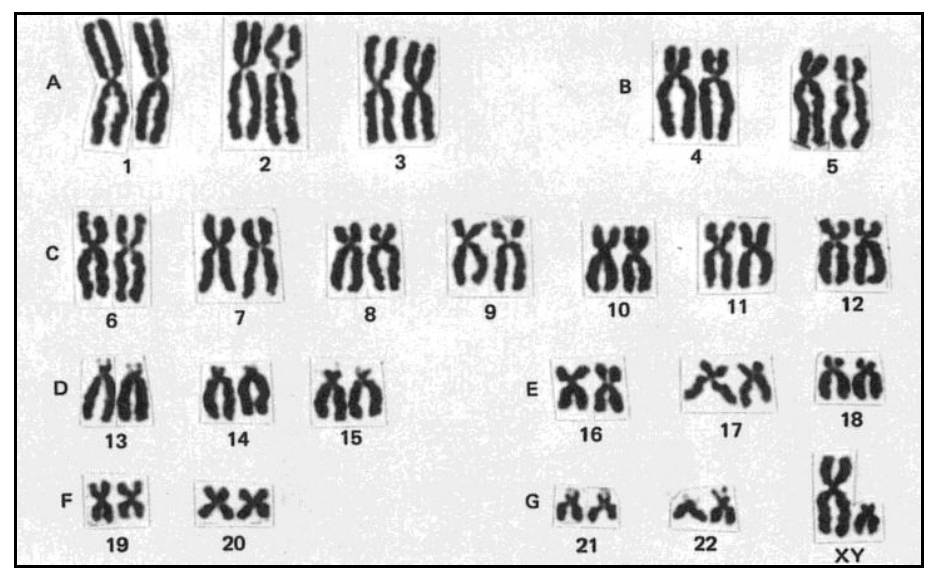

FIGURA 19 - Cariótipo de cromossomos humanos (Hsu, 1979 apud Carr, 2014)

Kasahara (2003, p.2) descreve os seguintes critérios para a distribuição dos cromossomos nos sete grupos:

O grupo A é composto pelos 6 maiores cromossomos. O primeiro par é metacêntrico, o segundo é submetacêntrico e o terceiro é também metacêntrico, porém de tamanho menor que o par 1.

O grupo B inclui 2 pares submetacêntricos. $\mathrm{O}$ tamanho de seus braços curtos equivale a um terço de seus braços longos. Os 2 pares de homólogos não são distinguíveis morfologicamente entre si.

O grupo C compreende 15 cromossomos no homem e 16 na mulher, pois o cromossomo X é incluído nesse grupo. São metacêntricos ou submetacêntricos, sendo difícil a identificação individual dos mesmos. Contudo, por serem os maiores do grupo, o sexto e o sétimo par são frequentemente identificados, assim como o X, cujo tamanho está entre o sétimo e oitavo par. Algumas vezes, um dos elementos do nono par (raramente ambos) pode ser reconhecido, em virtude de uma constrição secundária proximal nos braços longos.

O grupo D envolve 3 pares de acrocêntricos de tamanho médio. São cromossomos portadores de constrição secundária e satélite nos braços curtos, porém nem sempre visíveis. Os pares 13, 14 e 15 não são distinguíveis morfologicamente entre si.

O grupo E abrange 3 pares de cromossomos dos quais o décimo sexto é metacêntrico enquanto o décimo sétimo e décimo oitavo são submetacêntricos. O par 16 é identificado morfologicamente, o que nem sempre acontece com os demais, embora o par 17 tenha os braços curtos ligeiramente maiores que os do par 18. 
O grupo F inclui o décimo nono e vigésimo pares, os menores metacêntricos, não são distinguíveis morfologicamente entre si.

E o grupo $\mathrm{G}$ compreende 4 cromossomos na mulher e 5 no homem, pois o cromossomo Y está incluído neste grupo. Os pares vigésimo primeiro e vigésimo segundo, e o Y são os menores acrocêntricos. Os pares 21 e 22 apresentam constrição secundária e satélite, nem sempre visíveis, nos braços curtos. Não é possível a distinção morfológica desses dois pares. O Y é identificável em muitos casos pelo tamanho maior ou menor que o dos outros autossomos, e pela posição paralela dos braços longos. O cromossomo Y se caracteriza também pela ausência de constrição secundária e satélite, não participando da associação de acrocêntricos.

Nos últimos anos vários tipos de refinamentos técnicos foram introduzidos, a fim de detectar e quantificar danos induzidos ao DNA por agentes genotóxicos (Valgôde, 2008).

Para estimar a dose de radiação em indivíduos expostos pode-se adotar métodos físicos (dosimetria física) e métodos biológicos. Dentre os biológicos, encontra-se o citogenético, que utiliza as aberrações cromossômicas formadas nos linfócitos sanguíneos periféricos (LSP) expostos à radiação ionizante e que relaciona a frequência destas aberrações radioinduzidas (principalmente os dicêntricos e anéis cêntricos) com a estimativa de dose absorvida tanto in vitro quanto in vivo, método denominado dosimetria citogenética (Da Silva, 1997).

Entre as técnicas citogenéticas estão: técnica de aberrações cromossômicas, troca entre cromátides irmãs, micronúcleo, hibridização in situ fluorescente-FISH; entre as técnicas bioquímicas estão: gradientes alcalinos de sacarose, eluição alcalina e neutra eletroforese alcalina em gel, sedimentação de nucleoide e medidas viscoelásticas de DNA (Valgôde, 2008). A técnica de aberrações cromossômicas foi empregada neste trabalho e por isso será abordada com maiores detalhes na próxima seção.

\subsubsection{Técnica de aberrações cromossômicas}

Para possibilitar análise cromossômica, as células são submetidas à algumas preparações. Seguem as etapas descritas por Kasahara (2003, p.1), para o procedimento mais rotineiramente empregado:

"Uma amostra de sangue é colhida assepticamente, com auxílio de uma seringa contendo o anticoagulante heparina. Algumas gotas do sangue total podem ser imediatamente inoculadas em meio de cultura ou pode- 
se esperar a sedimentação das hemácias, de modo que seja semeado o plasma contendo leucócitos. O meio de cultura contém os elementos necessários para a sobrevivência e multiplicação das células, antibióticos para impedir o crescimento de bactérias e fitohemaglutinina que o a agente mitogênico. Essa substância tem o papel de promover a diferenciação dos linfócitos que retornam à condição blástica $e$ readquirem a capacidade de se dividir. As culturas são mantidas em estufa a $37^{\circ} \mathrm{C}$ durante 48 a 72 horas. A colchicina é, então, adicionada e após mais algum tempo de incubação, as células são submetidas a tratamento hipotônico com solução de cloreto de potássio 0,075M e a fixação com uma mistura de metanol e ácido acético, na proporção três para um. A suspensão celular obtida é gotejada em lâminas de microscopia, que são posteriormente destinadas a diferentes técnicas de coloração e de marcação cromossômica. As metáfases das preparações citológicas são analisadas e fotografadas ao microscópio.."

A coloração pode ser feita por meio de técnicas convencionais ou pelas técnicas de coloração diferencial. As técnicas convencionais coram os cromossomos por igual, isto é, não faz distinção entre determinado tipo de cromatina, composição do DNA ou de proteínas. Já nas técnicas de coloração diferencial, estão incluídas as técnicas de bandeamento cromossômico que coram principalmente, ou exclusivamente, um determinado tipo de cromatina (Guerra e De Souza, 2002).

Para a detecção de possíveis anomalias, por meio da técnica citogenética de aberrações cromossômicas, as metáfases são submetidas a técnica de coloração convencional. Assim, os efeitos genotóxicos são descritos em termos da morfologia dos cromossomos. Por meio dela não é possível a diferenciação precisa entre cromossomos de morfologia muito parecidas, tampouco a detecção de pequenas perdas de material genético ou deleções muito pequenas, ou alterações na localização do referido material dentro de um cromossomo (inversão). De modo que, utilizando-se esta técnica, a identificação individual dos cromossomos nem sempre é possível (Kasahara, 2003).

Apesar destas limitações, a técnica convencional de aberrações cromossômicas apresenta grande importância para o conhecimento da estrutura cromossômica normal e patológica, e é amplamente utilizada para diversos fins, por exemplo, em genética toxicológica, biomonitoramento e em dosimetria biológica, em virtude da sua sensibilidade, pela riqueza de informações e pela sua taxa espontânea para cromossomos dicêntricos ser relativamente baixa (IAEA, 1986, apud Da Silva, 2001, p.23). 


\subsection{Processamento de imagens digitais}

Processamento de imagens digitais é o nome dado ao conjunto de técnicas voltadas para a manipulação de uma imagem por computador.

As aplicações do processamento de imagens estão em quase todos os ramos da atividade humana. Em medicina, os avanços em processamento de imagens vêm permitindo tanto o desenvolvimento de novos equipamentos que utilizam imagens para o diagnóstico médico quanto a maior facilidade de interpretação de imagens produzidas por equipamentos tradicionais, como por exemplo o de raio X. Em biologia, o processamento automático de imagens obtidas de microscópios facilita a execução de tarefas laboratoriais com alto grau de precisão e repetibilidade (Marques Filho e Neto, 1999).

O processamento inicial dos dados brutos é conhecido como préprocessamento. Nesta etapa, podem ser aplicadas diversas técnicas, como o realce de contraste, histogramas de representação das intensidades dos pixels, aplicação de filtros entre outras modificações que visam melhorar a qualidade inicial da imagem e/ou adequálas de forma a aumentar as chances para o sucesso dos processos seguintes (Gonzalez e Woods, 1992).

Outra etapa do processamento, a que frequentemente as imagens digitais são submetidas é a etapa de segmentação. Esta etapa divide uma imagem de entrada em partes ou objetos constituintes. Em geral, a segmentação automática é uma das tarefas mais difíceis no processamento de imagens digitais (Gonzalez e Woods, 1992). No caso de reconhecimento de padrões deste trabalho, o papel básico da segmentação é extrair cada cromossomo do fundo (background) da imagem de célula metafásica, e dividi-los em subimagens independentes.

Um procedimento de segmentação robusto pode favorecer substancialmente a solução bem sucedida de um problema de imageamento. Contudo, algoritmos de segmentação fracos ou erráticos quase sempre levam a falha no processamento. A saída do estágio de segmentação é constituída tipicamente por dados em forma de pixels (Gonzalez e Woods, 1992).

Em muitas aplicações, faz-se necessário o desenvolvimento de um método para que as características de interesse sejam enfatizadas. O processo de descrição, também chamado extração de características, procura selecionar características que resultem em alguma informação quantitativa de interesse ou que sejam básicas para discriminação entre classes de objetos (Gonzalez e Woods, 1992). 
No caso da classificação de cromossomos, um exemplo de característica importante seria a quantidade de centrômeros, já que esta informação pode auxiliar na diferenciação entre alguns tipos de cromossomos, portanto neste caso, o algoritmo deve enfatizá-la.

Na etapa de extração de caracteristicas um modelo é criado, baseado em características surgidas de uma base de conhecimentos empíricos ou de processos interativos sobre os dados puros. Posteriormente temos uma representação da realidade objetiva que queremos classificar (De Mesquita, 2002).

Outra etapa de processamento de imagens envolve reconhecimento de padrões em imagens e interpretação. Para Tou e Gonzalez (1974), padrão pode ser definido como propriedades que possibilitam o agrupamento de objetos semelhantes dentro de uma determinada classe ou categoria, mediante a interpretação de dados de entrada, que permitam a extração de características relevantes desses objetos. E entende-se por classe de um padrão um conjunto de atributos comuns aos objetos de estudo.

Reconhecimento é o processo que atribui um rótulo a um objeto, baseado na informação fornecida pelo seu descritor. A interpretação envolve a atribuição de significado a um conjunto de objetos reconhecidos (Gonzalez e Woods, 1992).

No caso de reconhecimento de padrões em imagens, os dados da imagem de entrada são medidos por um algoritmo e selecionados segundo o conteúdo de informações relevantes para a decisão, e muitas vezes passam por um processo de redução de sua dimensionalidade para que possam ser usados pelo classificador, que o designará à classe que melhor o represente. Na TAB. 1 são apresentadas algumas das aplicações de reconhecimento de padrões em imagem em diferentes áreas do conhecimento (Lopes, 2012).

O reconhecimento de padrões pode ser dividido em dois tipos: o primeiro, baseado em classificação supervisionada, onde o padrão de entrada é um membro de uma classe que é definida valendo-se de uma base de conhecimento formada por padrões conhecidos; e o segundo baseado em classificação não supervisionada, onde o padrão é associado a uma classe desconhecida até então. Dado um conjunto de padrões, métodos não supervisionados os agrupam em função de sua disposição no espaço de características (De Mesquita, 2002).

A abordagem empregada no presente trabalho envolve classificação não supervisionada, por meio do uso de um tipo de Rede Neural Artificial (RNA) denominado 
Self-Organizing Map (SOM). De acordo com De Mesquita (2002), as RNAs são sistemas computacionais que se baseiam nas características de aprendizado e funcionamento das redes de neurônios biológicos. As principais características das redes neurais são que elas têm a habilidade de aprender relações de entrada e saída não-lineares, usam procedimentos de treinamento sequencial, e se adaptam aos dados.

\section{TABELA 1 - Aplicações de reconhecimento de padrões em imagem}

\begin{tabular}{|c|c|c|}
\hline Aplicação & Padrão de Entrada & Classes (saída) \\
\hline $\begin{array}{l}\text { Reconhecimento óptico de } \\
\text { caracteres }\end{array}$ & imagem de um documento & caracteres/palavras \\
\hline Busca na internet & documento texto/imagem & categoria semântica \\
\hline Filtro de e-mails & e-mail & spam/normal \\
\hline Identificação de pessoas & face, iris, impressão digital & acesso de usuários credenciados \\
\hline $\begin{array}{c}\text { Diagnóstico auxiliado por } \\
\text { computador }\end{array}$ & imagem microscópica & células saudáveis/doentes \\
\hline $\begin{array}{l}\text { Reconhecimento de alvos } \\
\text { militares }\end{array}$ & imagem óptica ou infravermelho & tipo do alvo \\
\hline $\begin{array}{c}\text { Seleção automática de } \\
\text { qualidade }\end{array}$ & imagem em esteira de produção & níveis de qualidade \\
\hline $\begin{array}{c}\text { Análise de sequências de } \\
\text { DNA }\end{array}$ & sequência de DNA & gene conhecido/desconhecido \\
\hline $\begin{array}{l}\text { Estimação de expressão } \\
\text { gênica }\end{array}$ & imagem de microarray & intensidades/classes \\
\hline Análise de expressão gênica & expressão gênica & similaridade entre os elementos dos clusters \\
\hline Inferência de redes gênicas & perfil de expressão temporal & rede de regulação estimada \\
\hline
\end{tabular}

Fonte - Lopes, 2012

O SOM, também conhecido por mapa de Kohonen, é principalmente usado para agrupamento ("clustering") de dados e mapeamento segundo suas características (Kohonen, 2001). Ao se utilizar o SOM um conjunto de dados é particionado em grupos, baseados em características específicas, tais que os pontos dentro de um grupo (cluster) sejam mais similares do que os pontos de outros grupos. O processo de aprendizado envolve a atualização da arquitetura da rede e pesos da conexão de forma que a rede possa desempenhar a tarefa de classificar (De Mesquita, 2002).

\subsection{Redes neurais artificiais}

As primeiras pesquisas nesta área surgiram na década de 40 no século $\mathrm{XX}$, quando Warren McCulloch e Walter Pitts publicaram em 1943 o artigo "A logical calculus of the ideas immanent in nervous activity"; nele foi apresentado o primeiro modelo de um 
sistema neural baseado nos conhecimentos que existiam na época sobre estruturas biológicas (Pfeffermann, 2009).

McCulloch era psiquiatra e neuroanatomista e Pitts era matemático. Eles propuseram um modelo de sistema neural que ficou conhecido como McCulloch-Pitts. No sistema proposto as unidades básicas, os neurônios, são bastante simples no seu funcionamento. E a conectividade entre esses elementos simples proporcionam a riqueza de processamento e a capacidade computacional (Da Silva Filho, 2012). A Figura 20 mostra o modelo de neurônio de McCulloch-Pitts.

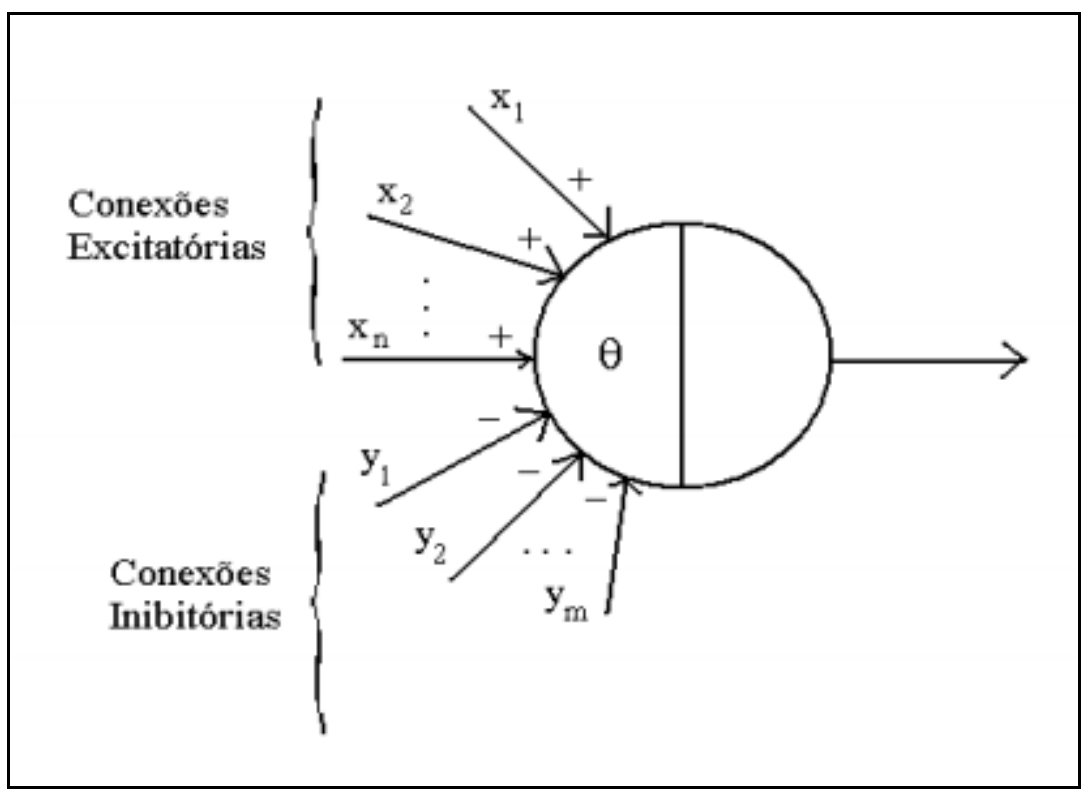

FIGURA 20 - Modelo de neurônio de McCulloch-Pitts (Da Silva Filho, 2012)

Observando-se a Figura 20, a rede neural é constituída por linhas direcionadas, sem pesos, ligando os neurônios. Onde as conexões excitatórias são representadas por $x$, as inibitórias por $y$, e $\theta$ representa o limiar de ativação. Se num dado instante de tempo, pelo menos uma das conexões inibitórias $\left(y_{i}\right)$, for igual a 1 , o neurônio é inibido. Caso nenhuma delas seja igual a 1, o neurônio calcula apenas a soma das conexões excitatórias $(\Sigma x i)$ e a compara com o limiar de ativação $(\theta)$. Se $\Sigma x i$ for maior ou igual a $\theta$, o neurônio dispara; caso seja menor, ele não dispara.

Da Silva Filho (2012, p.6) descreve que o modelo de McCulloch e Pitts está baseado nas seguintes hipóteses:

"1. A atividade de um neurônio é binária, ou seja, a cada instante o neurônio, ou está disparando (atividade 1), ou não está disparando (atividade 0); 
2. A rede neural é constituída por linhas direcionadas, sem pesos, ligando os neurônios. Essas linhas (inspiradas nas sinapses) podem ser excitatórias ou inibitórias;

3. Cada neurônio tem um limiar fixo $\theta$, de maneira que ele só dispara se a entrada total chegando a ele, num dado instante, for maior ou igual a $\theta$;

4. A chegada de uma única sinapse inibitória num dado instante evita absolutamente o disparo do neurônio, independentemente do número de sinapses excitatórias que estejam chegando conjuntamente com a sinapse inibitória;

5. Um sinal leva uma unidade de tempo para passar de um neurônio da rede para outro. Isso procura reproduzir o atraso sináptico."

As RNAs podem ser definidas como "um sistema de processamento de dados que consiste de um grande número de elementos processantes (neurônios artificiais) altamente interconectados numa arquitetura baseada na fisiologia do sistema nervoso central do cérebro" (Tsoukalas e Uhrig, 1996).

De acordo com De Mesquita (2002), o funcionamento de uma RNA, pode ser resumido da seguinte forma: existe um neurônio artificial que, em geral, apresenta um conjunto de entradas que corresponderiam aos dendritos do neurônio biológico. Os dados que utilizam cada uma destas entradas são modificados por um peso (cuja função seria semelhante à junção sináptica biológica) que pode ser negativo ou positivo dependendo se tal entrada deve ser inibida ou amplificada respectivamente. Cada neurônio artificial em geral apresenta duas etapas de processamento dos dados. Na primeira, ocorre a soma dos dados referentes às entradas já modificadas pelos pesos resultando em um valor único, e na segunda, este valor agregado obtido passa por uma função não linear chamada de função de ativação, que gera a saída da unidade.

Os neurônios de saída combinam toda a informação recebida e fornecem saídas que podem, entre outras aplicações, controlar um movimento, reconhecer ou classificar um padrão, prever o estado futuro de um sistema de acordo com o estado atual (Da Silva Filho, 2012).

De Mesquita (2002) descreve a arquitetura das RNAs, da seguinte forma: os neurônios são arranjados em uma sequência de camadas conectadas. Estas conexões podem ser: 1) completas, no qual todos os neurônios da rede são interconectados; 2) completa entre camadas, o que significa que cada neurônio da camada anterior é conectado com todos os outros da camada posterior; ou 3) parcial. A arquitetura básica da rede neural artificial pode ser definida como um grafo direto no qual cada nó $i$ tem uma função de 
transferência ou de ativação $f$. O processamento de um neurônio artificial pode ser descrito pela equação 1:

$$
y_{i}=f\left(\sum_{j=1}^{n} w_{i j} x_{j}-\theta_{i}\right)
$$

onde $\theta_{i}$ é o limiar de ativação, $x_{j}$ são os vetores de entrada daquele neurônio, ${ }_{i j}$ são os pesos a cada uma destas entradas, $f$ é a função de ativação citada acima e $\boldsymbol{n}$ é o número de vetores de entrada conectados.

Um arranjo típico de arquitetura de rede neural é mostrado na Figura 21.

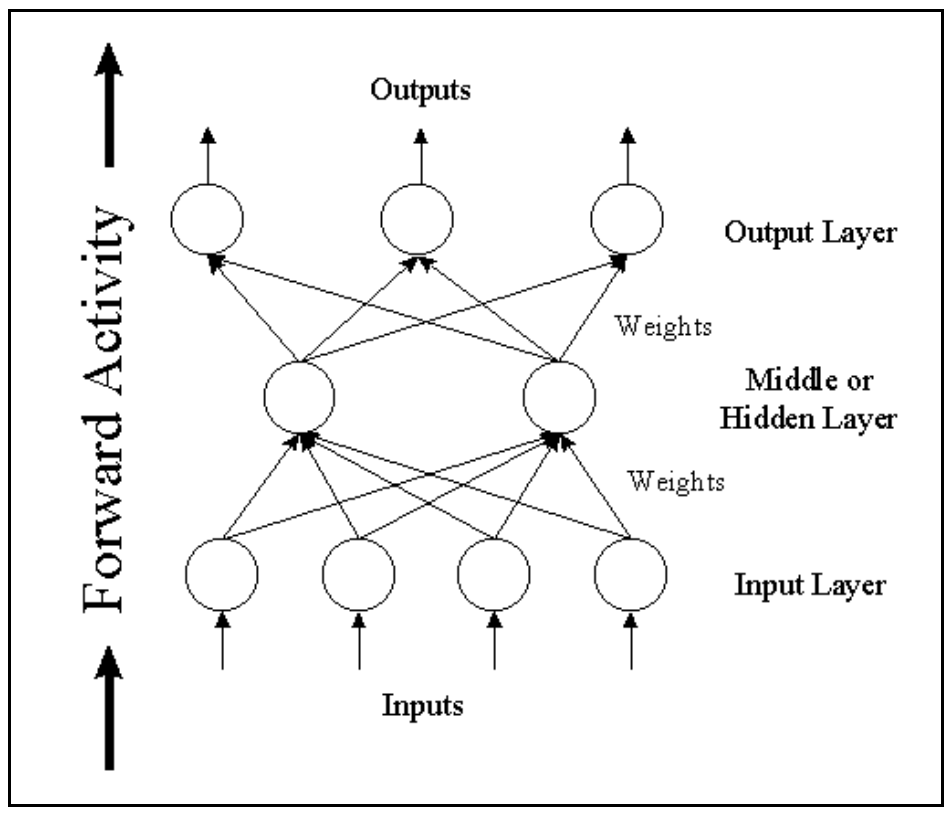

FIGURA 21 - Exemplo de arquitetura de rede neural artificial (Caudill e Butler, 1989)

As redes neurais artificiais em geral são submetidas a duas fases diferentes. A primeira fase consiste no processo de aprendizado da rede e é geralmente chamado de treinamento. Posteriormente, a rede já com o aprendizado acumulado (memorizado), por meio dos vetores-peso modificados na fase de treinamento, funciona como uma função de transferência entre a entrada e a saída (De Mesquita, 2002).

\subsection{Mapas auto-organizáveis}

O conceito de mapas auto-organizáveis (SOM -Self Organizing Map) foi desenvolvido em 1982 por Teuvo Kohonen, e imita a ação das redes neurais biológicas, onde cada neurônio aceita diferentes sinais de neurônios vizinhos, e os processa. Os mapas 
auto-organizáveis analisam dados por meio de agrupamentos com o objetivo de descobrir estruturas e padrões (Kohonen, 1982a).

O mapa auto-organizável de Kohonen consiste de duas camadas. Uma camada simples de neurônios (chamada de camada de Kohonen) altamente interconectados (conexões laterais) dentro da camada e fora da rede por uma camada de entrada (acumuladora) que é totalmente conectada aos neurônios da camada de Kohonen por intermédio de pesos ajustáveis.

Este tipo de rede utiliza algoritmos que se baseiam no aprendizado competitivo e não supervisionado. Assim, ao se apresentar uma entrada à rede, os neurônios competem entre si e o vencedor tem seus pesos ajustados para responder melhor ao estímulo, de forma que a única informação apresentada à rede são os padrões de entrada (Vesanto et al., 2000a).

De acordo com Haykin (2009), a formação do mapa auto-organizável pode ser compreendida em três etapas: a competitiva, a cooperativa e a adaptativa.

$\mathrm{Na}$ fase competitiva, para cada padrão de entrada, os neurônios de saída competem entre si, mediante alguma função discriminante. $\mathrm{O}$ neurônio com o maior valor de função discriminante é denominado vencedor da competição, ou também chamado de BMU (Best Matching Unit). Entre as funções de distâncias utilizadas para quantificar a semelhança entre os vetores da rede, uma das mais empregadas é a distância Euclidiana $\left(\mathrm{D}_{\mathrm{E}}\right)$, definida pela equação 2:

$$
D_{E}=\sqrt{\left(x_{1}-y_{1}\right)^{2}+\left(x_{2}-y_{2}\right)^{2}+\cdots+\left(x_{n}-y_{n}\right)^{2}}
$$

onde $x_{n}$ são as coordenadas dos vetores de entrada e $y_{n}$ são as coordenas dos vetores protótipo (pesos das redes auto-organizáveis).

$\mathrm{Na}$ etapa cooperativa o neurônio vencedor determina a localização espacial de uma vizinhança topológica de neurônios excitados, fornecendo, desta forma, as bases para a cooperação entre os neurônios vizinhos.

Na última fase, a adaptativa, os neurônios excitados aumentam os valores de sua função discriminante em relação ao padrão de entrada, por meio de ajustes em seus pesos sinápticos. Consequentemente, a grade vai se tornando auto-organizável. 


\subsubsection{Treinamento SOM}

Durante o treinamento, os nós com proximidade topográfica, dentro de um certo raio geométrico, interagem entre si para modificarem seus pesos de acordo com a entrada. Com isso, é gerado um efeito de suavização local destes vetores pesos que a medida em que são realizadas as repetições do processo geram um ordenamento global do mapa (De Mesquita, 2002). A equação 3 descreve o processo de treinamento considerandose os limites de convergência.

$$
\mathrm{m}_{\mathrm{i}}(t+1)=\mathrm{m}_{\mathrm{i}}(t)+\mathrm{h}_{\mathrm{ci}}(t)\left[\mathrm{x}(\mathrm{t})-\mathrm{m}_{\mathrm{i}}(t)\right]
$$

onde $\mathrm{m}_{\mathrm{i}}(t+1)$ corresponde ao vetor de peso atualizado, $\mathrm{m}_{\mathrm{i}}(t)$ corresponde ao vetor de peso anterior, $\mathrm{h}_{\mathrm{ci}}(t)$ corresponde a função de vizinhança e $\mathrm{x}(\mathrm{t})$ corresponde ao vetor de entrada. Os valores inicias de $m_{i}$ podem ser arbitrários, ou aleatórios, e os valores de $t$ na equação são inteiros e se referem às iterações

A função $h_{c i}(t)$ é chamada função de vizinhança e funciona como elemento suavizador dos pesos no processo de atualização durante o treinamento. Para que haja convergência do algoritmo é necessário que $h_{c i}(t) \rightarrow 0$ quando $t \rightarrow \infty$. Geralmente $h_{c i}(t)$ $=h\left(\left\|r_{c}-r_{i}\right\|, t\right)$, onde $r_{c} \in R^{2}$ e $r_{i} \in R^{2}$ são os vetores de localização dos nós $c$ e $i$, respectivamente, no mapa. A forma da função $h_{c i}$ incluindo sua largura média acarreta o grau de suavização da "superfície elástica” a ser ajustada aos dados (Kohonen, 2001).

A função de vizinhança mais utilizadas na literatura é a Gaussiana, descrita na equação 4 .

$$
\mathrm{h}_{\mathrm{ci}}(\mathrm{t})=\alpha(\mathrm{t}) \cdot \exp \left(\frac{\left\|\mathbf{r}_{\mathbf{c}}-\mathbf{r}_{\mathbf{i}}\right\|^{2}}{2 \sigma^{2}(\mathrm{t})}\right)
$$

onde o valor escalar $\alpha(t)$ decresce monotonicamente com $t$, e está associado a taxa de aprendizagem (normalmente assume valores entre 0 e 1 ), o termo $\left\|r_{c}-r_{i}\right\|$ corresponde a distância entre o neurônio $c$ e o neurônio $i$ que esta sendo analisado, e o parâmetro $\sigma(t)$ define a largura da distribuição correspondente ao raio geométrico de vizinhos que terão seus pesos ajustados

Após o treinamento da RNA a localização dos neurônios se torna ordenada entre si de tal forma que é criado um mapa, onde as coordenadas de cada neurônio, estão relacionadas às características de entrada (De Mesquita, 2002). 
Aplicações envolvendo o SOM exigem a elaboração de diferentes mapas variando a topologia, tamanho do mapa, função de aprendizado, função de vizinhança, entre outras, de tal forma a encontrar aquele mapa que obtenha os melhores resultados (Vesanto et al., 2000a). Conforme será abordado na próxima seção.

\subsubsection{Criação e configuração da rede no SOM Toolbox}

Neste trabalho foi criada uma rede neural auto-organizável utilizando-se o SOM Toolbox do Matlab ${ }^{\circledR}$. Esta ferramenta foi desenvolvida por uma equipe de pesquisas da Universidade da Finlândia que contou com a participação de Teuvo Kohonen, pesquisador que propôs o modelo dos mapas auto-organizáveis. A principal finalidade desta Toolbox é facilitar o estudo envolvendo as redes Kohonen. Algumas das etapas relacionadas ao uso básico do SOM Toolbox do Matlab ${ }^{\circledR}$ serão apresentadas a seguir.

\subsubsection{Construção do conjunto de dados}

De acordo com Vesanto et al. (2000b), para inserir os dados no Matlab ${ }^{\circledR}$, podese utilizar funções padrões do Matlab ${ }^{\circledR}$, tais como 'load' e 'scanf' ou pode-se utilizar uma função disponível no Toolbox chamada de 'som_read_data'.

A 'som_read_data' é usada para ler arquivos no formato texto com colunas separadas por espaço. A primeira linha da base de dados deve conter o número de variáveis, na segunda linha precedidos de '\#n' deve conter os nomes das variáveis. Para cada amostra de dados é possível inserir labels ou rótulos para a fase de classificação após o treinamento. É importante dizer que estes labels que identificam a classe na qual a amostra pertence não afetam o processo de agrupamento feito pelo SOM.

Desta forma, os dados de entrada são armazenados em uma variável de tipo 'struct' do Matlab ${ }^{\circledR}$ que permite o armazenamento em campos para dados numéricos (.data), e strings (.label).

Uma matriz de dados numéricos deve ter o tamanho [dlen $\mathrm{X}$ dim], onde dlen é o número de amostras, e dim é o número de variáveis. Se $D$ é uma dessas matrizes, cada linha $D(i,:)$ da matriz corresponde a uma amostra, e cada coluna $D(:, i)$ é uma coleção de valores para uma única variável. O campo no mapa auto-organizável que armazena essas informações é denominado livro de códigos (.codebook). Uma matriz numérica $D$ pode ser convertida para uma variável tipo 'struct' utilizando-se a função 'som_data_struct'. 
Dados do tipo 'string' são colocados no campo '.labels' da estrutura de dados. O tamanho deste campo é dado por [dlen $\mathrm{X} m l$ ], onde $m l$ é o número máximo de rótulos de uma amostra. Cada linha armazena os rótulos de uma amostra então os rótulos $s D$.labels $(i,:)$ e os valores numéricos $s D$.data $(i,:)$ são corespondentes entre si.

\subsubsection{Configuração do SOM}

De acordo com Vesanto et al. (2000b), a topologia no SOM Toolbox é dividida em dois fatores: a estrutura local lattice (formato de vizinhança) que pode ser hexagonal ou retangular, mostrada na Figura 22, e a forma global do mapa que podem ter formato de folha, cilíndrico ou toroide, e visualizados na Figura 23.

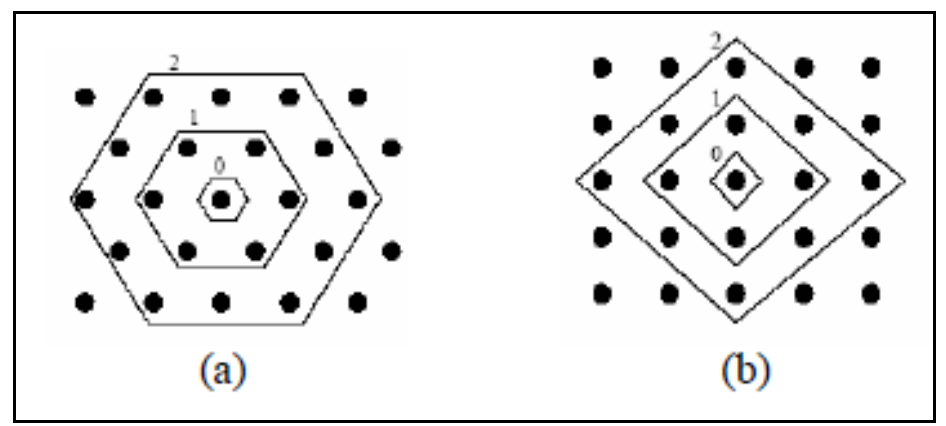

FIGURA 22 - Exemplos de vizinhança discreta: (a) Estrutura Hexagonal e (b) Estrutura retangular (Vesanto et al., 2000b)

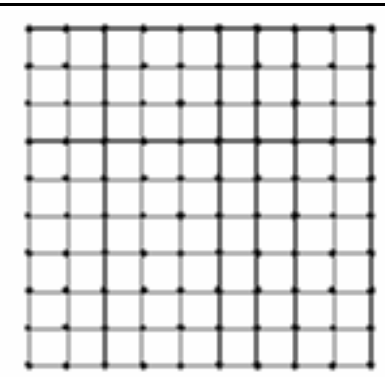

(a)

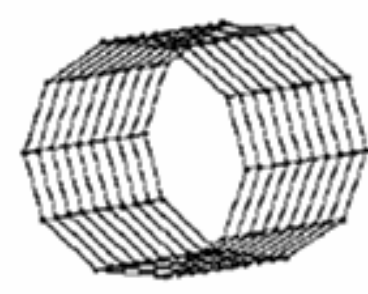

(b)

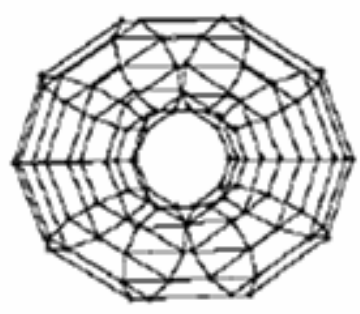

(c)

FIGURA 23 - Diferentes formatos do mapa: (a) o formato de folha (sheet), (b) cilíndrico (cylinder), e (c) toroide (toroid) (Vesanto et al., 2000b)

No SOM Toolbox é possível realizar inúmeras combinações dos parâmetros citados além de funções de visualização e análises dos resultados.

Uma das principais funções do Toolbox é a 'som_make'. Capaz de criar, inicializar e treinar um SOM com parâmetros default e em duas fases: a primeira fase é a 
de ordenação do mapa e a segunda é a fase de convergência. Ao utilizar a função 'som_make' os seguintes parâmetros são utilizados: algoritmo de treinamento - batch; função de inicialização - lininit; topologia dos neurônios - grade; formato de vizinhança hexagonal; função de vizinhança - gaussiana, função para decréscimo da taxa de aprendizagem - inversa, raio inicial - 1/8 do maior lado do mapa, raio final - valor padrão é 1, mas durante a fase de ordenamento, o raio final corresponde a 1/4 do raio inicial; duração do treinamento - na fase de ordenamento é de 10 vezes a razão entre número de unidades e quantidade de dados e durante a fase de convergência o valor é quarenta vezes esta mesma razão (De Faria et al., 2014).

O treinamento de um SOM pode ser feito utilizando-se as rotinas som_seqtrain que treina a rede com o algoritmo de treinamento sequencial, ou a rotina som_batchtrain que utiliza o algoritmo batch (lote) no treinamento da rede.

Para o modo sequencial a atualização dos pesos sinápticos dos neurônios no arranjo é feita toda vez que um item de dados é apresentado à rede, ou seja, toda vez que uma amostra do vetor de entrada é inserida na rede, a distância entre ele e todos os vetores pesos do SOM são calculados usando a medida da distância euclidiana. O neurônio vencedor (chamado BMU) será aquele que tiver a menor distância entre o próprio e a entrada. Depois de encontrado o BMU os vetores de peso do SOM são atualizados fazendo com que eles se aproximem cada vez mais da entrada. Para os vizinhos mais próximos topologicamente o mesmo procedimento é feito. $\mathrm{O}$ treinamento é geralmente feito em duas fases. A primeira fase começa com a taxa de aprendizagem e raio de vizinhança bem grande. Na segunda fase tanto a taxa de aprendizagem quanto o raio de vizinhança são pequenas (Vesanto et al., 2000b).

Já no treinamento em lote os pesos sinápticos são atualizados apenas após a apresentação de todos os elementos do conjunto de dados utilizados. Na maioria das vezes este algoritmo é significativamente mais rápido que o anterior.

Uma das rotinas existentes no SOM Toolbox, para inicialização da rede é chamadas de 'lininit' (inicialização linear). Na 'lininit', primeiramente são calculados os autovalores e autovetores dos dados de entrada. Em seguida, os vetores de peso são inicializados de uma forma ordenada ao longo dos dois maiores autovetores da matriz de covariância dos dados de entrada. Isto faz com que a convergência da rede seja mais rápida dispensando assim a fase de ordenamento, sendo necessária apenas a fase de convergência (Vesanto et al., 2000b). 
O número de unidades no mapa, a menos que seja explicitamente definido, é determinado pela função SOM_TOPOL_STRUCT. A fórmula heurística utilizada nesta função para determinar a quantidade de neurônios (munits) do mapa de tamanho médio é a

seguinte: munits $=5 \mathrm{X}$ dlen $^{0,54321}$, onde dlen representa a quantidade de amostras no mapa. Pode-se optar entre um mapa de tamanho grande, médio ou pequeno. Por padrão (default) um mapa grande tem seu tamanho igual a 4 vezes o número de neurônios (calculado anteriormente), ou seja mapsize $=4 \mathrm{X}$ munits, e um mapa pequeno tem seu tamanho igual a 0,25 vezes a quantidade de unidades, ou seja mapsize $=0,25 \mathrm{X}$ munits.

Vários outros parâmetros de configuração do mapa auto-organizável podem ser definidos, entretanto, segundo Kohonen (2001) o processo de seleção dos parâmetros do SOM não é crucial para mapas de algumas centenas de nós, salvo a escolha do tamanho da vizinhança (raio). Se esta vizinhança for muito pequena no começo do treinamento, pode não haver ordenamento global do mapa. Isto pode gerar um conjunto de falsos agrupamentos. Isto pode ser evitado pela escolha de um valor relativamente grande para o raio inicial de treinamento.

\subsubsection{Normalização do conjunto de dados}

A normalização é importante para que nenhuma das variáveis venha a ter influência demasiada no resultado do treinamento. Isto porque, o algoritmo utilizado no Toolbox usa a distância euclidiana entre vetores, sendo assim ao colocar todas as variáveis em uma mesma escala, evita-se que ocorram valores em escalas muito grandes e valores muito pequenos no conjunto de dados, pois certamente os valores muito grandes teriam um maior impacto nas medidas das distâncias (Vesanto et al., 2000b).

\subsubsection{Visualização do mapa}

Para facilitar a análise quantitativa do mapa e dos dados nos casos em que o número de unidades do SOM é grande, as unidades similares precisam ser agrupadas, ou seja "clusterizadas". Um cluster Q significa particionar um conjunto de dados em um conjunto de cluster $\mathrm{Q}_{\mathrm{i}}, \mathrm{i}=1, \ldots, C$. No agrupamento "crisp", cada amostra de dados pertence a exatamente um cluster. Já a "clusterização" fuzzy é uma generalização da “clusterização" crisp, onde cada amostra tem um grau variável de participação em todos os clusters. A clusterização também pode ser baseada na mistura dos modelos. De forma que, 
um agrupamento ideal é uma partição que minimize as distâncias dentro do cluster e maximize as distâncias entre os clusters (Vesanto e Alhoniemi; 2000).

A inspeção visual do mapa, pode fornecer uma idéia inicial do número de cluster no SOM, assim como o relacionamento espacial. O método mais amplamente utilizado para visualização da estrutura de agrupamento do SOM é a técnica de matriz de distâncias unificada (U-matrix). De acordo com Vesanto e Alhoniemi (2000), a U-matrix mostra as distâncias entre os vetores de protótipos de unidades do mapa de vizinhança. Altos valores da $U$-matrix significam grande distância entre as unidades vizinhas do mapa, e portanto indicam as fronteiras do cluster. Já que os clusters são tipicamente áreas uniformes de valores baixos.

A principal função utilizada na SOM Toolbox para visualização do mapa é a 'som_show' que mostra dentre a U-matrix, o plano de componentes, os rótulos dos dados, e outras visualizações que possam vir a ajudar na análise dos resultados.

Outra função bastante utilizada é a 'som_clustercolor', que projeta o vetor de protótipos em um espaço de cores atribuindo cores semelhantes para as unidades do mapa pertencentes ao mesmo cluster. Nesta função a cor é determinada por meio do cálculo da média do valores RGB iniciais de unidades pertencentes ao mesmo cluster.

\subsubsection{Análise dos resultados}

O SOM Toolbox apresenta duas métricas para avaliação da qualidade do mapa gerado após o processo de aprendizagem. As métricas são: erro da quantização vetorial (Qe) e o erro topográfico $(T e)$.

O erro de quantização representa a média das distâncias entre cada vetor de dados $\left(m_{\mathrm{c}}\right)$ e o correspondente vetor de pesos $\left(v_{n}\right)$ do neurônio vencedor (BMU). Estima-se que quanto menor o erro de quantização, mais bem ajustado o neurônio vencedor estará aos vetores de entrada. O erro de quantização é calculado através da equação 5.

$$
Q e=\frac{1}{N} \sum_{n=1}^{N}\left\|m_{c}-v_{n}\right\|
$$

onde $m_{c}$ representa cada vetor de dados, $N$ é a quantidade total de vetores de dados $m_{c}$, e o $v_{n}$ correspondente ao vetor de pesos do neurônico vencedor (BMU). 
O erro topográfico quantifica a capacidade do mapa em representar a topologia dos dados de entrada. É calculado verificando-se para todas as entradas qual é o neurônio mais bem ajustado e também o segundo neurônio mais bem ajustado. O erro topográfico é calculado através da equação 6.

$$
T e=\frac{1}{N} \sum_{n=1}^{N} u\left(v_{n}\right)
$$

onde a função $u\left(v_{n}\right)$ é igual a ' 1 ' se a primeira e a segunda BMUs de $v_{n}$ são adjacentes, e '0’ (zero) caso contrário.

\subsubsection{Práticas recomendadas para a construção de um bom mapa}

Segundo Kohonen (2001, p.159), embora seja possível obter um mapa sem levar em conta nenhum tipo de precaução, é interessante prestar atenção em algumas recomendações a fim de obter um mapa mais estável, bem orientado e menos ambíguo. Segue algumas recomendações:

Estrutura hexagonal: para inspeção visual é recomendado que se use a estrutura hexagonal, pois não favorece as direções horizontais e verticais como no caso da estrutura retangular.

Realce dos casos raros: em muitos problemas práticos casos importantes (dados de entrada) podem ocorrer com frequência estatística tão pequena que eles não são capazes de ocupar um espaço no mapa. Por isso, estes casos podem ser realçados na aprendizagem a fim de melhorar a qualidade do mapa. Uma forma de solucionar este problema seria repetir estas amostras de forma aleatória em um número suficiente de vezes durante o processo de aprendizagem.

Padronização dos vetores de entrada: a orientação dos vetores de protótipo no espaço do mapa está diretamente relacionada a escala dos componentes do vetor de entrada. Isso porque o algoritmo SOM mede a distância entre cada elemento do vetor. Se uma variável possui os valores no intervalo de $[0, \ldots, 1000]$ e outra na faixa de $[0, \ldots, 1]$, a primeira irá praticamente dominar a organização do mapa em razão de seu maior impacto sobre as distâncias medidas. Por isso normalmente é desejado que as variáveis sejam igualmente importantes. A maneira padrão de alcançar este objetivo é colocar todas as variáveis em uma mesma escala, de modo que suas variâncias sejam iguais a 1 . 


\section{MATERIAIS E MÉTODOS}

Nesta seção são apresentados os recursos utilizados e as etapas de desenvolvimento da metodologia proposta por este trabalho.

\subsection{Infra-estrutura}

O desenvolvimento desta metodologia engloba três ambientes: dependências do reator de pesquisa (IEA-R1) CEN-IPEN onde as amostras de tecido humano foram irradiadas para que aberrações cromossômicas fossem estimuladas propositadamente; laboratório de cultura celular do Centro de Biotecnologia CB-IPEN onde foi realizada a preparação das células e aquisição das imagens; e por fim, o ambiente de desenvolvimento do software a ser projetado.

\subsubsection{Dependências do reator de pesquisa (IEA-R1)}

Parte das imagens utilizadas neste trabalho é proveniente de amostras de tecido humano que foram irradiadas em instalações do reator de pesquisas (IEA-R1). Estas instalações foram projetadas pela equipe do Centro de Engenharia Nuclear (CEN) cujo responsável foi o Dr. Paulo Rogério Pinto Coelho e possibilitou a utilização da radiação emitida pelo reator IEA-R1 em algumas das amostras das células analisadas por este projeto. As condições térmicas da irradiação por nêutrons são de $32.2 \pm 0.1 \mathrm{~Gy} / \mathrm{h}$ de taxa de dose, com $25 \%$ de contaminação gama para 3.5MW de energia operacional do reator (Souza, 2011; Coelho et. al., 2008).

\subsubsection{Laboratório de Cultura Celular do Centro de Biotecnologia (CB)}

O laboratório de cultura celular do $\mathrm{CB}$, cuja responsável é a Dra. Kayo Okazaki, conta com uma sala estéril, com os seguintes itens relacionados: fluxos laminares TROX e FORMA SCIENTIFIC, estufas de CO2 FORMA SCIENTIFICA, estufa bacteriológica FANEM e microscópio invertido CARL ZEISS; conta também com salas de preparação e lavagem, com os seguintes itens: centrífugas SORVALL e FANEM, banhosmaria FANEM, autoclave, balança METTLER, geladeiras e freezer, estufa FANEM para esterilização e purificador de água - sistema Milli-Q; e por fim, a sala de microscopia, com os seguintes itens relacionados: fotomicroscópio CARL ZEISS, microscópio de 
fluorescência CARL ZEISS, lupas CARL ZEISS e microscópio NIKON modelo Eclipse (Souza, 2011).

\subsubsection{Equipamento e sistema operacional para o desenvolvimento do aplicativo}

Para o desenvolvimento do aplicativo utilizou-se microcomputadores do Centro de Engenharia Nuclear, que detém licenças do software Matlab ${ }^{\circledR}$ da MathWorks ${ }^{\mathrm{TM}}$ versão 2010a. Foram utilizados os seguintes acessórios do Matlab ${ }^{\circledR}$ SOM Toolbox, Image Processing Toolbox e Wavelet Toolbox.

Também foi utilizado um microcomputador pessoal, com processador

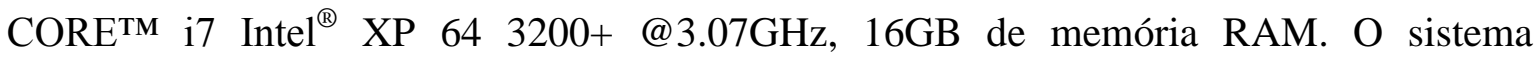
operacional utilizado foi o Microsoft ${ }^{\circledR}$ Windows 7.

\subsection{Apresentação da metodologia}

Esta metodologia envolve as seguintes etapas: aquisição das imagens de células metafásicas por meio de câmera fotográfica; organização da base de dados, individualização de cada cromossomo em subimagens independentes, extração de características relevantes, e a utilização dos mapas auto-organizáveis para a classificação dos cromossomos. Estas etapas serão descritas a seguir.

\subsubsection{Aquisição das imagens de células metafásicas}

As imagens analisadas no estudo foram fornecidas pelas pesquisadoras $\operatorname{Dr}^{\mathrm{a}}$. Kayo Okazaki e Dr ${ }^{\mathrm{a}}$. Márcia Augusta da Silva do CB - IPEN e são provenientes de duas situações distintas:

No primeiro caso são imagens de células de indivíduos que foram expostos à radiação para fins médicos. Os pacientes envolvidos foram submetidos a uma terapia para ablação de tecido remanescente de tireóide, denominada iodoterapia, tratamento esse em que o iodo radioativo é empregado. Amostras de sangue foram coletadas desses pacientes, para que pudessem ser feitas análises de seus cromossomos verificando possíveis danos causados pela radiação ionizante.

No segundo caso as imagens são referentes à amostras de tecido humano irradiadas nas dependências do reator de pesquisas (IEA-R1) CEN-IPEN para estimular o aparecimento de aberrações cromossômicas. 
Após ambos os processos as amostras foram preparadas de acordo com os procedimentos descritos na seção 3.1 Técnica de aberrações cromossômicas. Em seguida foi realizada a aquisição das imagens utilizadas neste trabalho.

As aquisições das imagens de células metafásicas foram realizadas por meio de uma câmera fotográfica comum Sony ${ }^{\circledR}$ modelo: Cyber-Shot DSC-P73, acoplada à ocular do microscópio Carl Zeiss. E de um uma câmera fotográfica Nikon modelo Rl acoplada à ocular do microscópio Nikon modelo Eclipse.

\subsubsection{Organização da base de dados}

A base de dados que inicialmente contava com 11 imagens de células metafásicas, provenientes do trabalho de Souza (2011), foi ampliada para um total de 256 imagens, por meio das quais foram identificados os seguintes cromossomos aberrantes, de acordo com o diagnóstico dado por um profissional citogeneticista: 8 cromossomos em anel; 13 cromossomos dicêntricos; 11 fragmentos acêntricos (deleção terminal); 4 cromossomos com lacuna (gap); 2 cromossomos tricêntricos; 15 double minute (deleção intersticial). Os demais cromossomos presentes na base de dados não apresentam nenhum tipo de aberração ou estas não puderam ser identificados visualmente pelo profissional citogeneticista.

Com base neste diagnóstico, as imagens presentes na base de dados foram separadas e organizadas de forma que se pudesse identificar, posteriormente, quais imagens apresentavam a ocorrência de cromossomo aberrante, e neste caso, qual tipo de aberração se tratava.

Em células humanas normais (que não possuem aberração numérica) o total de cromossomos é de 46, portanto nas 256 imagens de célula metafásica existem aproximadamente 11776 imagens cromossômicas.

É importante ressaltar que apesar da base de dados disponível para este trabalho contar com aproximadamente 11776 imagens de cromossomos individualizados, deste total, a grande maioria (11723 imagens) é de cromossomos normais, ou seja, apenas $0,45 \%$ dos cromossomos apresentam algum tipo de aberração.

Este número ainda é mais reduzido se levarmos em consideração apenas as imagens que apresentam os tipos de aberrações cuja metodologia desenvolvida neste trabalho se propõe a classificar (anel e dicêntrico) das quais estão disponíveis apenas 21 imagens. 
Neste trabalho, todas as imagens de células metafásicas que contêm cromossomos com aberração do tipo anel e dicêntrico, foram submetidas ao processo de segmentação, no qual foram obtidas aproximadamente 900 imagens de cromossomos individualizados. Deste total, considerou-se que 500 imagens de cromossomos individualizados seriam suficientes para representar uma ampla faixa de variações na morfologia cromossômica. Portanto, a partir do total de imagens de cromossomos individualizados foram selecionadas 500 imagens de acordo com base nos seguintes critérios:

O primeiro critério foi a seleção do maior número possível de imagens de cromossomos que apresentavam as aberrações a serem classificadas.

O segundo critério foi o descarte das imagens que continham cromossomos sobrepostos. Alguns pesquisadores, como é o caso Somasundaram e Kumar (2014) consideram que imagens com cromossomos sobrepostos ou conectados representam o maior desafio na análise automática de cromossomos. Vários trabalhos se dedicam à segmentação (separabilidade) deste tipo de imagens, pois a sobreposição pode gerar erros não apenas na contagem dos cromossomos, como também na identificação e classificação. Algumas sugestões de como tratar imagens sobrepostas são descritas no Capítulo 6 Conclusões e sugestões para trabalhos futuros, porém não são abordadas em detalhe por se considerar que a solução não faz parte da proposta deste trabalho, pois a dissertação concentra-se especificamente no desenvolvimento de uma metodologia de extração de características e classificação cromossômica.

O conjunto de 500 imagens selecionadas para treinamento e validação da rede neural artificial desenvolvida neste trabalho, é composto pelos seguintes cromossomos: 8 cromossomos em anel, 13 dicêntricos, e 479 cromossomos normais, sendo 84 acrocêntricos, 305 submetacêntricos e 90 metacêntricos.

\subsubsection{Individualização dos cromossomos em subimagens independentes}

Para a separação de cada um dos cromossomos presentes nas imagens de células metafásicas em subimagens independentes e para a padronização da posição dos cromossomos nestas subimagens é utilizado um conjunto de técnicas de pré-processamento previamente proposto por Souza (2011). Na Figura 24 são representadas as etapas pelas quais as imagens são submetidas. Em seguida é feita uma breve descrição de cada uma delas. 


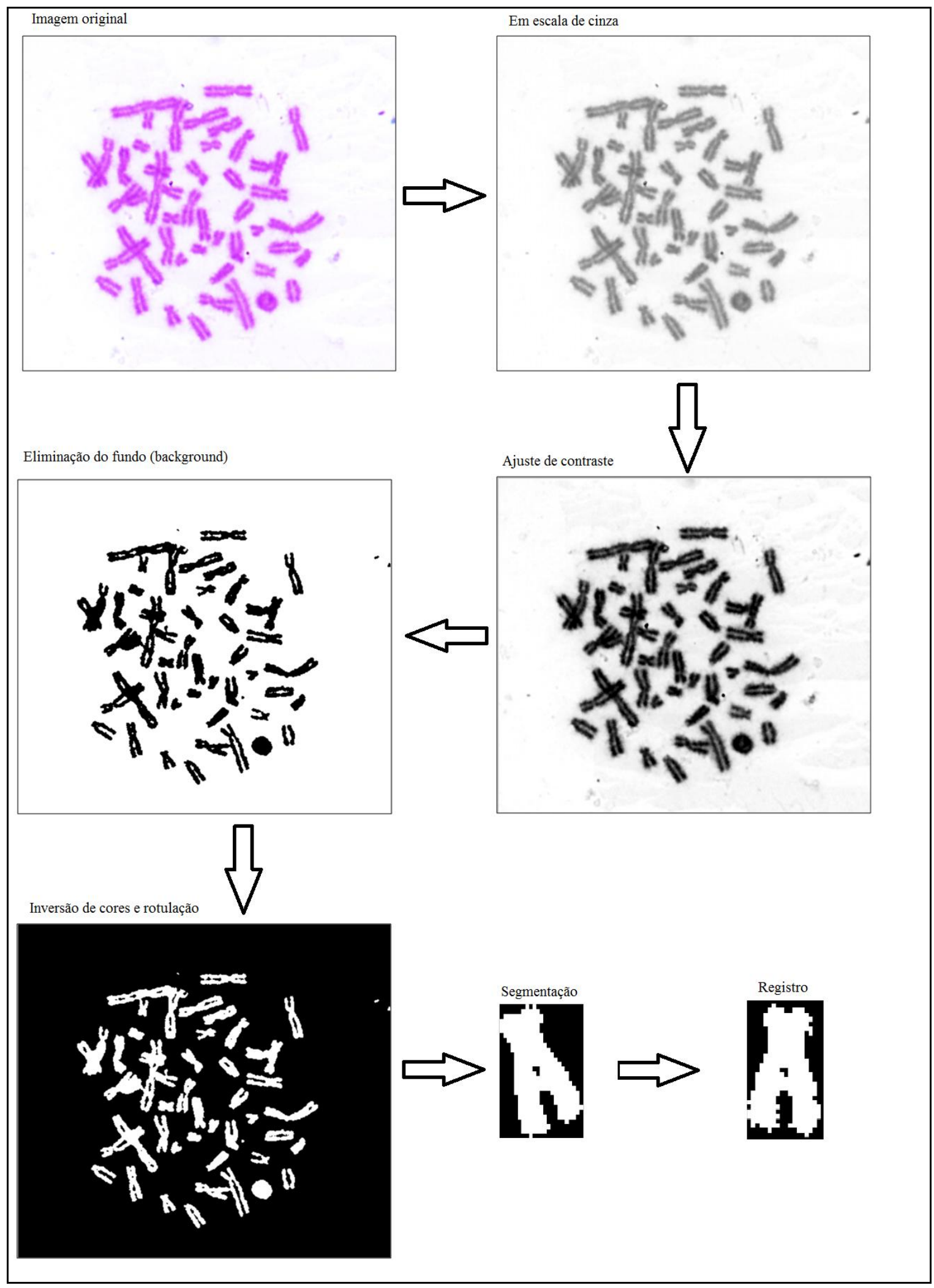

FIGURA 24 - Etapas pelas quais as imagens de células metafásicas são submetidas para se obter imagens de cromossomos individualizados e reposicionados 


\subsubsection{Transformação das imagens para tons de cinza}

Esta etapa é realizada aplicando-se a função 'rgb2gray' do Matlab ${ }^{\circledR}$ com o objetivo de transformar a imagem de célula metafásica, inicialmente em tons $R G B$ (redgreen-blue), para a escala em tons de cinza (gray scale) com intervalo de intensidades de pixels igual a [0-255]. A determinação das tonalidades de cinza da nova imagem é feita pela soma ponderada de 3 valores para todos os pixels que compõem a imagem metafásica de acordo com a equação 7.

$$
\text { Gray Level }=0.2989 * \mathrm{R}+0.5870 * \mathrm{G}+0.1140 * \mathrm{~B}
$$

onde $R, G$ e $B$ correspondem às intensidades de cores dos pixels em cada matriz de composição de uma imagem em RGB, respectivamente.

\subsubsection{Ajuste de contraste}

Nesta etapa é utilizada a função 'imadjust' do Image Processing Toolbox do Matlab $^{\circledR}$. O ajuste de intensidade é uma técnica que mapeia valores de intensidade de uma imagem para um novo range (faixa de variação). Por exemplo, uma imagem de baixo contraste cujo histograma indica que não há valores abaixo de 30 ou acima de 200 pode ser remapeada para que os valores de dados preencham toda a faixa de intensidade [0, 255], isso faz com que haja um aumento no contraste da imagem. A Figura 25 demonstra o histograma inicial e o resultado da manipulação do contraste aplicado sobre uma imagem cromossômica.
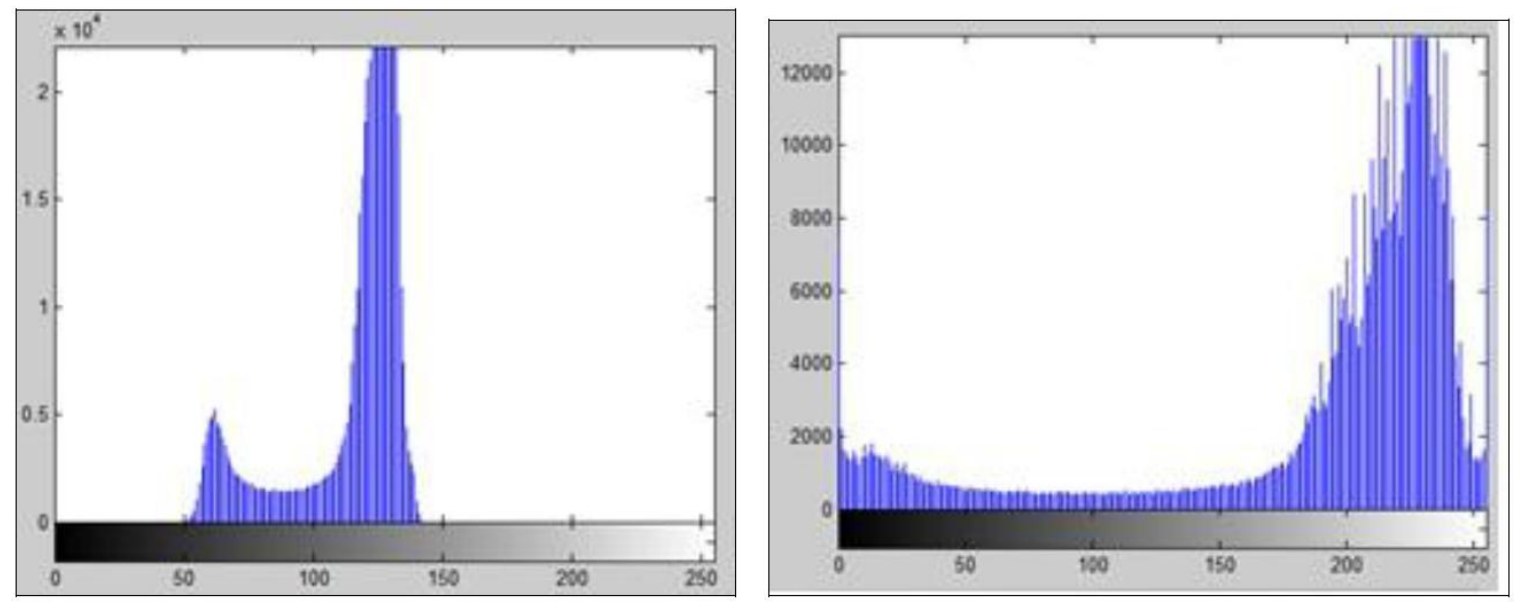

FIGURA 25 - A) Histograma de intensidades da imagem em tons de cinza; B) Histograma de intensidades da imagem após a aplicação do ajuste de contraste (Souza, 2011) 
De acordo com Souza (2011) dentre as diversas técnicas que envolvem operações em histogramas e "borramentos" nas imagens, o ajuste de contraste foi aplicado por preservar as características iniciais do histograma de intensidades após a transformação. Uma equalização histogramica, por exemplo, faria com que a diferença de intensidade dos pixels entre objeto e fundo fosse menos aparente.

\subsubsection{Eliminação do background}

Nesta etapa é utilizado um limiar (threshold) para separação dos cromossomos do fundo da imagem (background). Assim, todos os pixels pertencentes ao intervalo [limiar - 255] são eliminados da imagem, ou seja, preenchidos com o valor de 255 (branco).

Para cada imagem de célula metafásica utilizada neste trabalho, foi analisado visualmente, dentre três opções de valores de limiar, sessenta $(23,52 \%)$, setenta $(27,45 \%)$ e oitenta (31,37\%), a relação entre a separabilidade dos objetos e a preservação das características iniciais. $\mathrm{O}$ valor de limiar que apresentou melhor resultado na maioria das imagens foi setenta $(27,45 \%)$, e por isso este valor foi adotado na eliminação do background de todas as imagens.

Em seguida, utilizou-se a função 'im2bw' do Image Processing Toolbox do Matlab $^{\circledR}$ para convertê-la em imagem binária. Neste processo todos os pixels com intensidade maior do que o limiar são substituídos pelo valor 1 (branco) e todos os outros pixels são substituídos pelo valor 0 (preto).

\subsubsection{Inversão de cores e rotulação}

Após a eliminação do fundo da imagem é utilizada a função ‘bwlabeln’ do Image Processing Toolbox do Matlab ${ }^{\circledR}$ que retorna uma matriz contendo rótulos (labels) para os componentes, ou seja, é realizada a rotulação (labeling).

Para isso, inicialmente é necessário a inverter as cores das imagens, ou seja, os pixels que possuíam o valor 0 (preto) são substituídos pelo valor 1 (branco) e vice e versa. Com isso, o fundo da imagem (background) passa a ser representado pelo valor 0 (preto) e os cromossomos passam a ser representados pelo valor 1 (branco).

A inversão deve ocorrer para adequar a imagem à função 'bwlabeln' onde é considerado que os pixels com valor 0 compõem o background da imagem e os pixels iguais a 1 compõem um objeto. $\mathrm{O}$ algoritmo desta função testa as conectividades entre o pixel analisado pelo raster (conjunto de regras for que tem como função varrer a imagem 
analisada pixel a pixel) e os pixels adjacentes a ele. Assim, um objeto na imagem é formado por um conjunto de pixels que estão interconectados, todos os pixels de um mesmo objeto recebem o mesmo rótulo.

\subsubsection{Segmentação das imagens cromossômicas}

A segmentação divide uma imagem de entrada em partes ou objetos constituintes (Gonzalez e Woods, 1992). Neste trabalho, o papel básico da segmentação é extrair cada cromossomo da imagem metafásica. Com este objetivo, um raster (conjunto de regras for que tem como função varrer a imagem analisada pixel a pixel) é utilizado para identificar os subconjuntos de pixels de mesmo rótulo. Cada subconjunto é isolado em uma nova imagem que possui as dimensões da imagem cromossômica.

\subsubsection{Registro das imagens cromossômicas}

$\mathrm{O}$ registro consiste em colocar todas as imagens dos cromossomos individuais em uma posição padrão com o objetivo de facilitar a análise automática. Para isso a imagem de cada cromossomo é rotacionada de forma que o seu comprimento alinhe-se com a coordenada $y$ (eixo vertical do plano cartesiano), e, consequentemente a largura das cromátides se alinhem com a coordenada de $x$. Para isso foram aplicadas duas etapas:

Na primeira, a transposta da matriz (imagem cromossômica) é obtida a fim de alinhar o seu comprimento com a coordenada $y$ (eixo vertical do plano cartesiano), conforme o algoritmo mostrado a seguir:

Se $x>=y$

$$
A(x, y)=A(x, y) ;(\text { A matriz não sofre alterações })
$$

Senão

$$
\begin{aligned}
& \text { se } x<y \\
& \qquad A(x, y)=A(y, x) ;(\text { Obtêm-se a transposta da matriz) }
\end{aligned}
$$

fim se

fim se

$\mathrm{Na}$ segunda etapa, uma transformação rotacional é aplicada para que o cromossomo se posicione no eixo central da imagem; para isso é necessário identificar em quantos graus e para qual sentido a imagem deve ser rotacionada. 
Dois perfis são traçados: o primeiro na linha $y X 0.25$ e o segundo na linha $y X$ $0.75,25 \%$ e $75 \%$ da extensão total da coordenada $y$ do plano cartesiano, respectivamente. Os perfis são comparados quanto ao alinhamento dos eixos citados, onde três pontos de referência são identificados durante o escaneamento linha a linha. Em ambos os perfis traçados é detectado o primeiro e o ultimo pixel preenchido ao longo da linha selecionada no cromossomo. Por fim é calculado o pixel médio entre os dois pontos. Conforme o algoritmo mostrado a seguir:

$\operatorname{Se} f(x, y)=1$

Pinicial $=x$;

break; (um valor igual a 1 indica que o pixel está preenchido)

fim se

Raster em todo o perfil traçado,

se $f(x, y)=1$,

Pfinal $=x$;

fim se

Pmédio $=($ Pfinal + Pinicial $) / 2$;

Caso o pixel central do primeiro perfil estiver com o valor menor que o pixel central no segundo perfil, a imagem é rotacionada no sentido horário, caso contrário, no sentido anti-horário.

O cálculo do ângulo de rotação obtido dada seguinte forma:

$\alpha=$ arctangente (Pmédio2 / Pmédio1);

O reposicionamento das imagens cromossômicas é realizado utilizando-se a função 'imrotate' do Image Processing Toolbox do Matlab ${ }^{\circledR}$ com o método de interpolação nearest neighbor.

\subsubsection{Segmentação a partir das cores}

Para a separação de cada um dos cromossomos presentes nas imagens de células metafásicas em subimagens independentes encontra-se em desenvolvimento uma nova metodologia cuja segmentação é feita a partir das informações presentes nas cores 
das imagens. Na Figura 26, a imagem de uma célula metafásica é apresentada da seguinte maneira: imagem original na parte superior; à esquerda a imagem segmentada de acordo com os procedimentos propostos por Souza (2011) (limiar de setenta). E à direita a imagem é segmentada usando agrupamento K-means das cores da imagem.

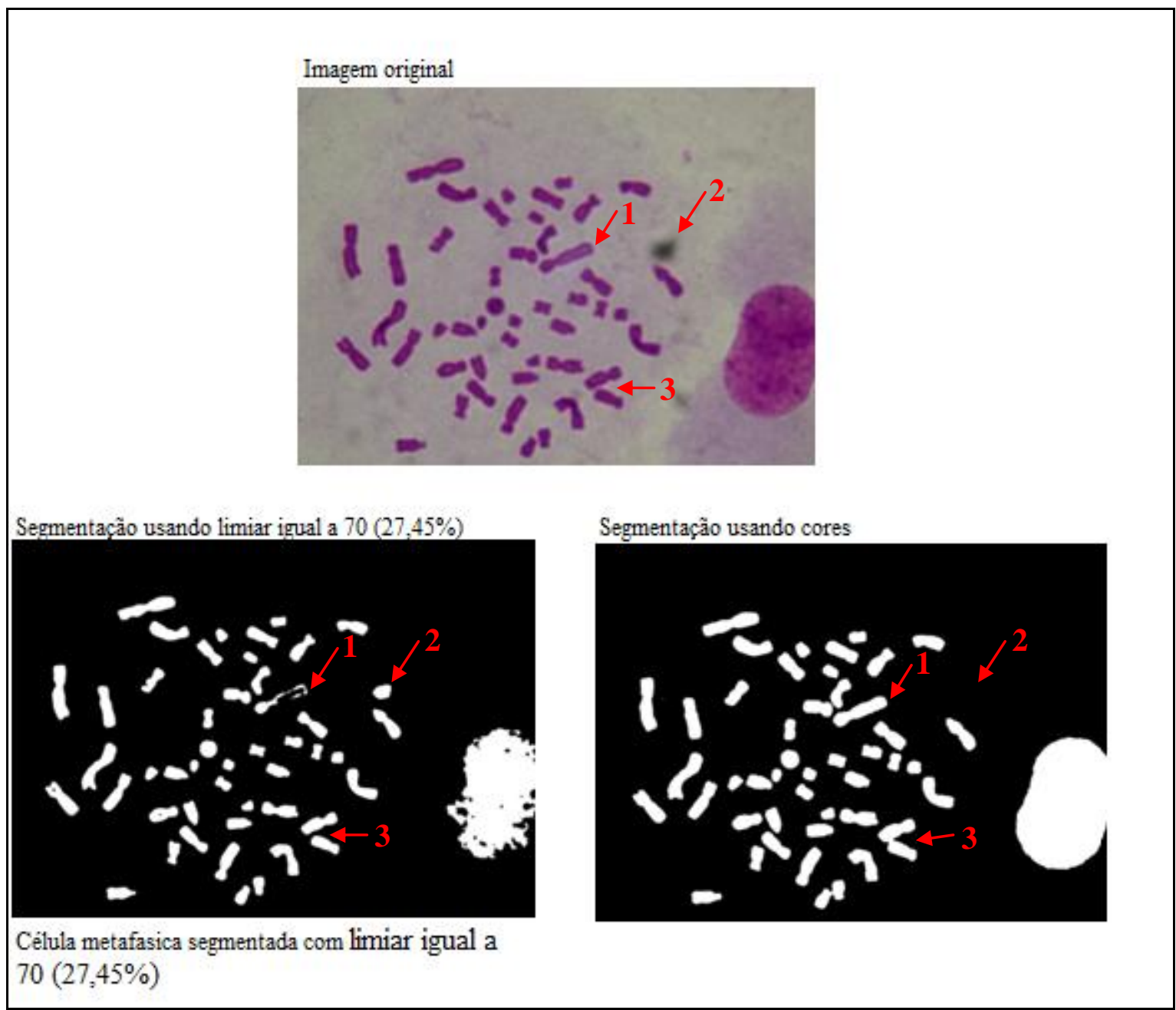

FIGURA 26 - Comparação entre diferentes técnicas de segmentação aplicadas em imagem de célula humana metafásica

Como destacado pela seta 1 da Figura 26, em relação a metodologia proposta por Souza (2011), as imagens segmentadas com base nas cores apresentaram maior preservação das informações iniciais, visto que ao utilizar o limiar sugerido pelo autor parte do cromossomo foi perdida devido à falsos negativos terem sido eliminados durante a remoção do background.

A segmentação com base nas cores se mostrou eficaz em eliminar problemas decorrentes do processo de gotejamento das células na lâmina (acúmulo de coloração nas células das imagens aquisitadas), como destacado pela seta dois da Figura 26. Entretanto, 
as imagens segmentadas por meio desta técnica apresentaram uma alta taxa de falsos positivos, dificultando segmentações de cromossomos que estão próximos uns dos outros na imagem da célula metafásica, como destacado pela seta três da Figura 26. Para se obter bons resultados valendo-se desta metodologia, é necessário que as imagens a serem analisadas apresentem cromossomos dispersos (afastados uns dos outros), caso contrário dois ou mais cromossomos que se encontrem próximos na imagem poderão se unir, e então serem interpretados como se fosse apenas um, o que ocasionaria erros na classificação.

Devido à necessidade de aperfeiçoamento da metodologia de segmentação dos cromossomos com base nas cores, utilizou-se nesta dissertação a metodologia de segmentação de imagens cromossômicas previamente proposta por Souza (2011), que está baseada na morfologia dos cromossomos dispostos nas imagens e desconsidera as cores das imagens.

\subsubsection{Classificação das aberrações cromossômicas}

Nas seções anteriores foi feita uma breve descrição das etapas pelas quais as imagens de células metafásicas são submetidas para se obter imagens de cromossomos individualizados e reposicionados. Tomando-se por base as imagens resultantes destas etapas, este trabalho, se concentra nas etapas de extração de características e classificação das aberrações cromossômicas, apoiando-se nos mapas auto-organizáveis. A proposta desta metodologia é de classificar dos cromossomos em: normais, anéis e dicêntricos.

Os tipos de dados usados pelo SOM Toolbox são do tipo tabela. Cada linha da tabela representa uma amostra dos dados. Os itens de cada linha são as variáveis ou componentes do conjunto de dados. Conforme apresentado na Figura 27.

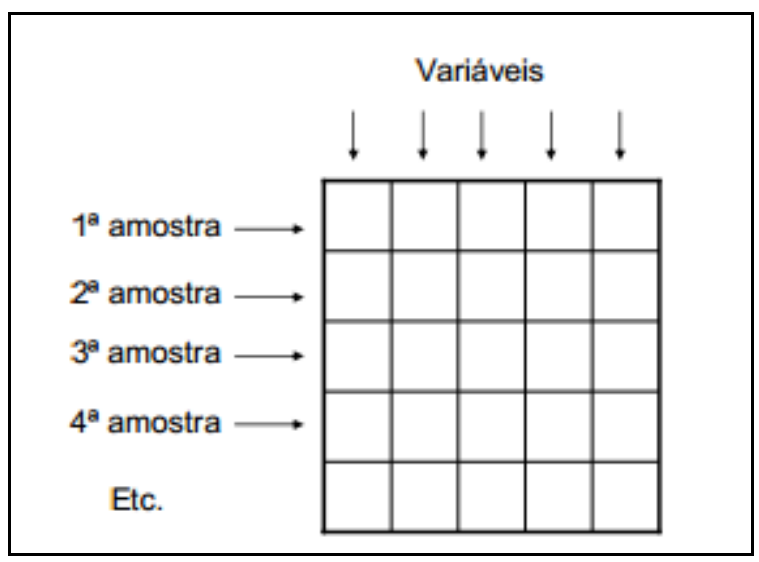

FIGURA 27 - Tabela de dados (Vesanto et al., 2000b) 
As variáveis devem conter propriedades (características) da amostra, compondo assim um vetor. Cada coluna da tabela contém o conjunto de valores da mesma variável para todas as amostras (Vesanto et al., 2000b).

\subsubsection{Redimensionamento}

As imagens obtidas após o processo de segmentação e registro, citados anteriormente, são binárias. Uma imagem pode ser definida como uma função bidimensional, $f(x, y)$, onde $x$ e $y$ são coordenadas espaciais, e a amplitude de $f$ nos pares de coordendas $(x, y)$ é chamada de intensidade da imagem naquele ponto. A imagem binária é uma matriz cujos valores de intensidade são representados apenas por 0 ou por 1 .

Neste trabalho cada amostra corresponde à imagem de um cromossomo, e na tentativa inicial, testou-se a eficiência de se aplicar todos os valores que representam os pixels, referentes a imagem cromossômica, inseridos diretamente na rede neural autoorganizável, isto é, sem a utilização de qualquer técnica de extração de características.

Para este fim, as matrizes bidimensionais, obtidas a partir das imagens cromossômicas, precisam ser redimensionadas antes de serem inseridas na rede SOM, porque, de acordo com Vesanto et al. (2000b), algumas das posições do vetor podem ser nulas, entretanto, para um melhor funcionamento do algoritmo estes devem ser evitados em razão do cálculo de distâncias ao qual eles são submetidos na fase de ordenação do mapa.

Como os cromossomos presentes em uma célula metafásica possuem variações no tamanho, os vetores que armazenam os pixels referentes às suas imagens foram redimensionados para um tamanho padrão para todas as imagens.

Ao realizar o redimensionamento, a informação referente ao tamanho original do cromossomo foi descartada, pois foi decidido enfatizar características relacionadas à forma (silhueta) apresentada pelo cromossomo que se deseja classificar, para a discriminação dos tipos cromossômicos (normais, anéis e dicêntricos) por meio do SOM.

Assim, foi desenvolvido um algoritmo que possibilita o redimensionamento das matrizes bidimensionais para que apresentassem 120 pixels de altura e 60 pixels de largura, para isso foi utilizada a função 'imresize' do Image Processing Toolbox do Matlab ${ }^{\circledR}$ com interpolação bilinear. 
A interpolação bilinear é uma extensão de interpolação linear para interpolação funções de duas variáveis (por exemplo, $\mathrm{X}$ e Y) em uma grade regular 2D. O cálculo da interpolação bilinear é realizado conforme exemplificado na Figura 28.
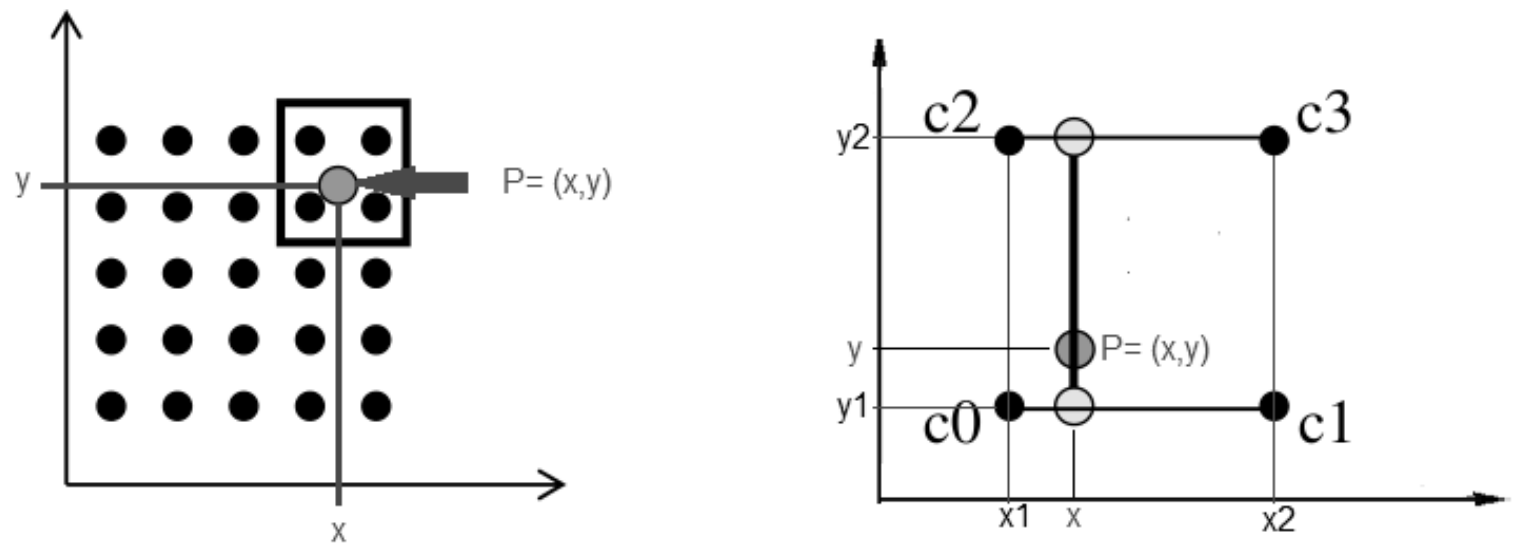

FIGURA 28 - Exemplificação da interpolação bilinear (Adaptado de Azevedo, 2011)

Suponha que se deseja encontrar o valor do pixel de saída no ponto $P=(x, y)$ e que os valores dos 4 pixels da vizinhança mais próxima são conhecidos: $\mathrm{c} 0=(\mathrm{x} 1, \mathrm{y} 1), \mathrm{c} 1=$ $(\mathrm{x} 2, \mathrm{y} 1), \mathrm{c} 2=(\mathrm{x} 1, \mathrm{y} 2)$ e $\mathrm{c} 3=(\mathrm{x} 2, \mathrm{y} 2)$

Por meio da interpolação bilinear, para se obter o valor deste pixel, primeiramente é realizada uma média ponderada na horizontal entre $c 0$ e $c l$, em seguida é realizada outra média ponderada entre $c 2$ e $c 3$. Por fim, é realizada uma nova média ponderada entre a resultante destas duas anteriores (Azevedo, 2011).

O próximo passo deste trabalho, foi transformar as matrizes bidimensionais redimensionadas em matrizes unidimensionais (vetores) relativas à cada cromossomo.

Esta transformação foi feita mediante ao concatenamento das linhas da matriz. Para isso após a última coluna da primeira linha, é inserido o valor da primeira coluna da segunda linha, e assim sucessivamente. Conforme o exemplo a seguir:

Suponha uma da matriz bidimensional $A=$

$$
\left|\begin{array}{ll}
2 & 3 \\
4 & 5 \\
6 & 7
\end{array}\right|
$$

A partir de $A$, obter-se a matriz unidimensional (vetor) $B=\quad\left[\begin{array}{l}2 \\ 2\end{array} 44567\right.$ ] 
Para realizar essa transformação foi utilizada a função 'reshape' do Matlab®. Conforme a seguinte sintaxe:

vetor $=$ reshape $($ imagem $, 1,7200)$;

onde o primeiro parâmetro corresponde a matriz bidimensional que representa a imagem do cromossomo individualizado após o redimensionamento (que possui 120 linhas e 60 colunas), o segundo parâmetro corresponde a quantidade de linhas que se deseja obter (no caso apenas uma) e o terceiro parâmetro a quantidade de colunas desejadas (no caso 120 x 60). Portanto todos os vetores resultantes desta transformação possuem 7200 posições.

\subsection{Primeiro teste}

Para a realização do primeiro teste na rede neural foram utilizados 12 vetores que representam características correspondentes às imagens dos seguintes tipos de cromossomos individualizados: 4 normais, 4 anéis e 4 dicêntricos.

Estes vetores foram agrupados em uma matriz denominada $\mathrm{D}$, na qual cada linha corresponde às características de um cromossomo e cada coluna corresponde a um pixel da imagem. A matriz $\mathrm{D}$ foi inserida numa estrutura denominada $s D$ por meio da utilização da função 'som_data_struct' do SOM Toolbox. Um rótulo (label) foi associado a cada vetor a fim de que fosse possível identificar a imagem que cada vetor representa. A sintaxe utilizada para a criação desta estrutura é apresentada a seguir:

$s D=$ som_data_struct $(D$, 'labels', $L)$;

onde o número de amostras de $D$ é igual a 12, e o número de variáveis é 7200. E cada linha de $L$ corresponde ao nome da imagem ao qual a amostra corresponde.

Empregou-se a função 'som_make' do SOM Toolbox, para criar, inicializar e treinar a RNA. Utilizou-se um mapa com 100 unidades (com a distribuição 10 linhas por 10 colunas), e os demais parâmetros de configuração assumiram os valores default da função 'som_make'. São eles: algoritmo de treinamento - batch; função de inicialização lininit; topologia dos neurônios - grade; formato de vizinhança - hexagonal; função de vizinhança - gaussiana, função para decréscimo da taxa de aprendizagem - inversa, raio inicial - 1/8 do maior lado do mapa, raio final - valor padrão é 1 , mas durante a fase de ordenamento, o raio final corresponde a 1/4 do raio inicial; duração do treinamento - na 
fase de ordenamento é de 10 vezes a razão entre número de unidades e quantidade de dados e durante a fase de convergência o valor é quarenta vezes esta mesma razão. A sintaxe utilizada é apresentada a seguir:

sM1 = som_make $\left(D\right.$, 'msize $\left.^{\prime},[10,10]\right)$;

Após o treinamento do SOM, os neurônios mais parecidos foram aglomerados em grupos (clusters) utilizando-se o agrupamento hierárquico, no qual é criada uma árvore de clusters. Esta árvore é uma hierarquia de vários níveis, onde os clusters em um nível são unidos com clusters do próximo nível. Neste trabalho, o intuito ao se realizar este agrupamento é que, seja formado um cluster para cada tipo cromossômico. Para a divisão dos grupos o seguinte procedimento foi aplicado:

Inicialmente foi encontrada a similaridade (ou dissimilaridade) entre cada vetor de protótipo da rede. Para isso, é calculada a distância entre objetos usando a função 'pdist' do Matlab ${ }^{\circledR}$. Com isso os objetos são agrupados em uma árvore binária.

Em seguida é feita a união entre pares de objetos que estão próximos utilizando-se a função 'linkage' do Matlab ${ }^{\circledR}$. Esta função utiliza a informação da distância gerado na etapa anterior para determinar a proximidade de um objeto em relação ao outro. Ao utilizar a 'linkage' os objetos que anteriormente estavam emparelhados em conjuntos binários, passam a ser agrupados em conjuntos maiores, até uma árvore hierárquica ser formada.

No próximo passo a função 'cluster' do Matlab ${ }^{\circledR}$ é empregada para determinar valores de corte que serão usados para dividir a árvore hierárquica em clusters. Esta função atribui um único cluster para todos os objetos abaixo de um limite de corte. Neste trabalho optou-se por utilizar o parâmetro 'maxclust' que constrói um máximo de $\boldsymbol{n}$ clusters utilizando o critério de "distância” fornecido pela função 'pdist' (citada anteriormente). Por meio do uso do 'maxclust' é encontrado o menor valor limite em que a árvore fornece $\boldsymbol{n}$ ou menos clusters, sendo o valor de $\boldsymbol{n}$ definido pelo programador. De forma empírica buscouse o número de agrupamentos adequado para cada mapa. A sintaxe utilizada para que os neurônios mais parecidos fossem aglomerados em 10 grupos (clusters) é apresentada a seguir:

class=cluster(linkage(pdist(sM1.codebook), 'complete'), 'maxclust',10); 
Utilizou-se a função 'som_clustercolor' do SOM Toolbox para que fosse atribuída uma cor a cada unidade do mapa de acordo com o agrupamento (clusters) que esta unidade pertence. Para cada agrupamento, a função fornece um código que corresponde a uma cor do sistema de coloração $R G B$. A sintaxe utilizada é apresentada a seguir:

C=som_clustercolor(sM1, class);

Para a visualização do mapa resultante, utilizou-se a funções 'som show' do SOM Toolbox juntamente com o parâmetro de cor $C$ obtido anteriormente, conforme a seguinte sintaxe:

figure, som_show(sM1,'color',C);

Em seguida, empregou-se a função 'som_autolabel' do SOM_Toolbox para que a BMU de cada vetor que foi inserido na rede fosse encontrada, e o rótulo deste vetor fosse adicionado à unidade do mapa onde está contida à sua BMU, conforme a seguinte sintaxe:

sMI=som_autolabel(sM1,sD, 'add');

Por último a função 'som_show_add' do SOM_Toolbox, e o parâmetro 'label' foram utilizados para mostrar estes rótulos, conforme a seguinte sintaxe:

som_show_add('label',sM1);

O resultado obtido para o primeiro teste é apresentado na Figura 29. 


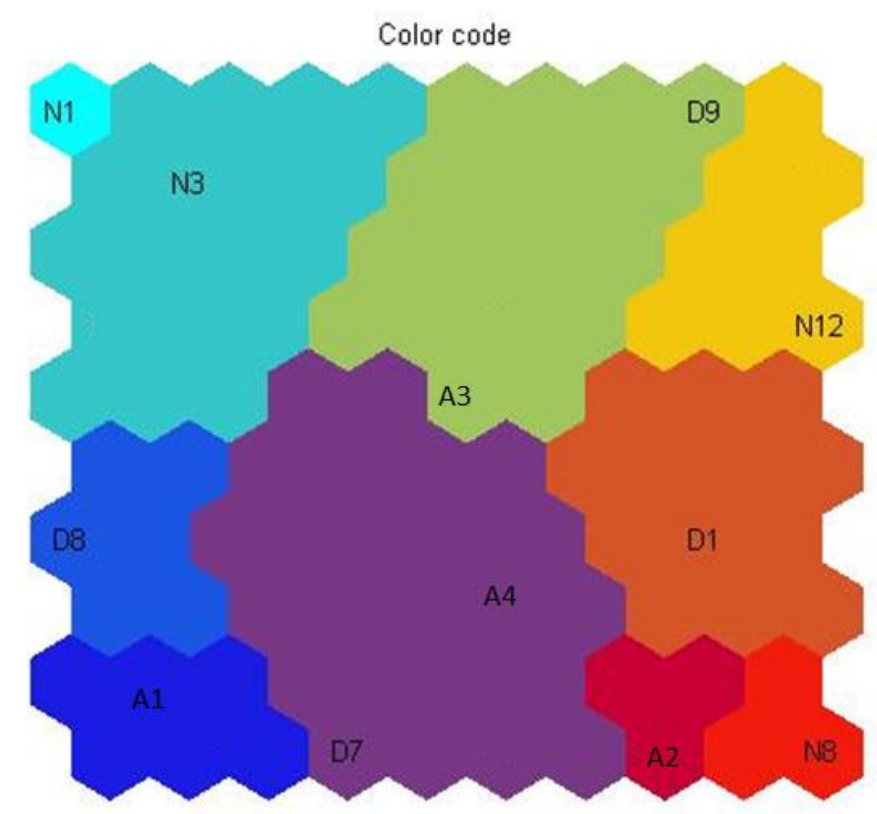

Figura 29 - Mapa resultante do primeiro teste. A função 'som_clustercolor' foi utilizada para colorir cada um dos agrupamentos com uma cor diferente

Na Figura 29, cada rótulo está posicionado na unidade do mapa em que se encontra o protótipo mais parecido com o vetor característico que ele representa (ou seja, a BMU). Os rótulos dos vetores característicos de cromossomos do tipo anel são iniciados pela letra "A", os do tipo dicêntrico são iniciados pela letra " $D$ " e os dos cromossomos normais são iniciados pela letra " $\mathrm{N}$ ".

Com base no mapa apresentado na Figura 29, é possível observar que praticamente cada rótulo, está posicionado em um agrupamento distinto, mostrando que a rede não identificou semelhanças entre a maioria dos vetores inseridos. Notou-se também que nos poucos agrupamentos que continham mais de um rótulo (somente 2 entre 10), estes eram iniciados por letras diferentes e, portanto, se tratavam de tipos cromossômicos distintos. Isto mostra que as semelhanças identificadas pela rede não estavam de acordo com o desejado neste trabalho, já que o intuito é que a rede identifique semelhanças nos vetores característicos de cromossomos de mesmo tipo. Com base neste resultado, pôde-se concluir que a inserção direta dos pixels correspondentes às imagens cromossômicas não forneceu as informações necessárias para que a RNA fosse capaz de discriminar os cromossomos nas três classes que se desejava: normais, anéis e dicêntricos.

Iniciou-se então, uma busca para identificar as características nas imagens cromossômicas que seriam relevantes para sua classificação, e o desenvolvimento de técnicas que objetivaram realçá-las antes de serem inseridas na RNA. 


\subsubsection{Distância horizontal entre bordas (DHB)}

Ao analisar a representação das distâncias horizontais entre as bordas de cada imagem cromossômica, é possível identificar a presença de constrições (locais onde há estreitamentos) que provavelmente corresponderão aos centrômeros, conforme ilustrado na Figura 30.

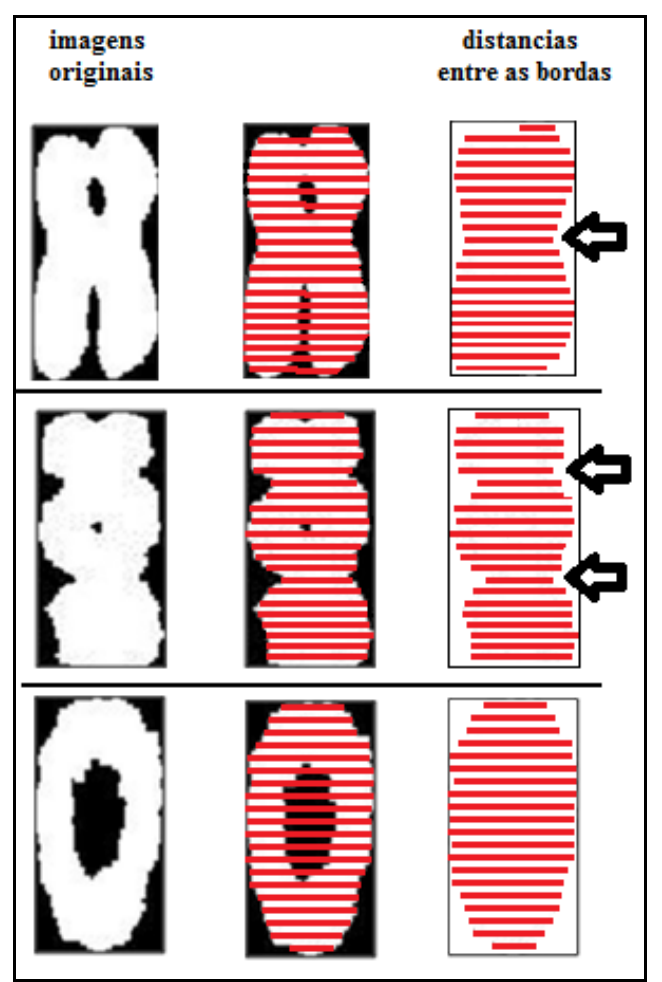

FIGURA 30 - Representação das distâncias horizontais entre as bordas. As setas indicam a presença de constrições

Com base nas constrições evidenciadas por meio da técnica de distâncias horizontais entre as bordas, seria possível classificar os cromossomos da seguinte maneira: caso houvesse apenas uma constrição, este cromossomo pertenceria à classe dos normais; caso houvesse duas constrições, este cromossomo pertenceria à classe dos dicêntricos e se nenhuma constrição fosse encontrada este cromossomo pertenceria à classe dos anéis.

Por isso, as distâncias horizontais entre bordas foram selecionadas para representar o cromossomo. Para a obtenção dessas distâncias são adotados os seguintes procedimentos: inicialmente é detectado o primeiro e o último pixel preenchido (válido) ao longo da primeira linha da matriz bidimensional que representa o cromossomo. Estes pixels correspondem às bordas do cromossomo. Em seguida é calculada a quantidade de pixels existentes entre eles. O resultado é armazenado na primeira posição de um vetor 
denominado $D H B$ (Distância Horizontal entre Bordas), conforme destacado pela linha em vermelho na Figura 31.

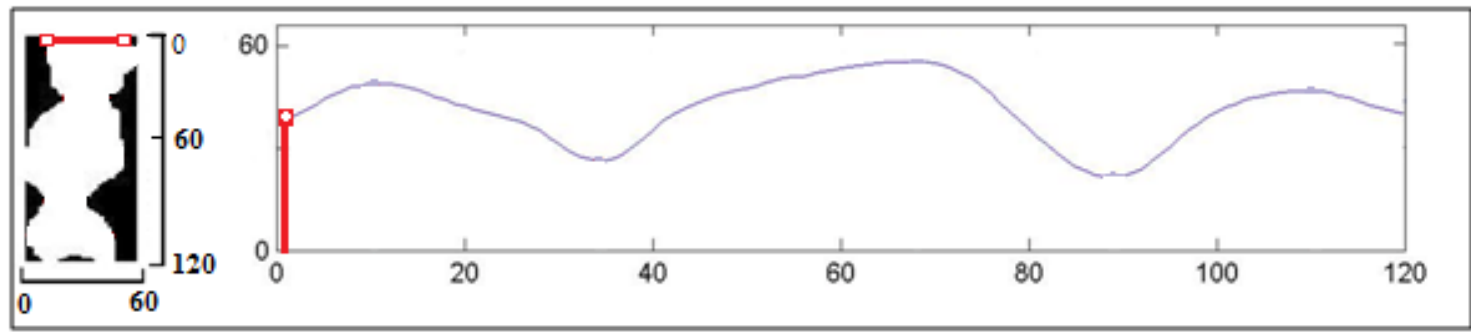

FIGURA 31 - Ilustração da forma como é obtido um $D H B$. À esquerda uma imagem bidimensional [120x60] que representa um cromossomo dicêntrico. À direita o gráfico do $D H B$ desta imagem

O próximo passo é calcular a distâncias entre as bordas da segunda linha da matriz, e armazenar na segunda posição do $D H B$. Este procedimento é repetido para todas as 120 linhas da matriz.

\subsection{Segundo teste}

Para que fosse possível verificar a resposta da RNA ao utilizar os $D H B s$ como entrada, foram feitos testes utilizando-se 24 vetores que representam as características correspondentes às seguintes imagens de cromossomos individualizados: 8 anéis, 8 dicêntricos e 8 normais. Os procedimentos para criação, inicialização, treinamento configuração e visualização da RNA foram os mesmos descritos no item 4.2.5.1.1 Primeiro teste. O mapa resultante do segundo teste, obtido ao de utilizar o número de agrupamentos máximo igual a 10, é apresentado na Figura 32.

Nesta Figura, os rótulos dos vetores característicos de cromossomos do tipo anel são iniciados pela letra " $A$ ", os do tipo dicêntrico são iniciados pela letra " $D$ " e os dos cromossomos normais são iniciados pela letra "N".

O mapa apresentado, revelou uma tendência à formação de 5 agrupamentos de cromossomos, de forma que, em cada grupo é predominante um determinado tipo cromossômico. A composição de cada grupo é apresentada na TAB. 2. 


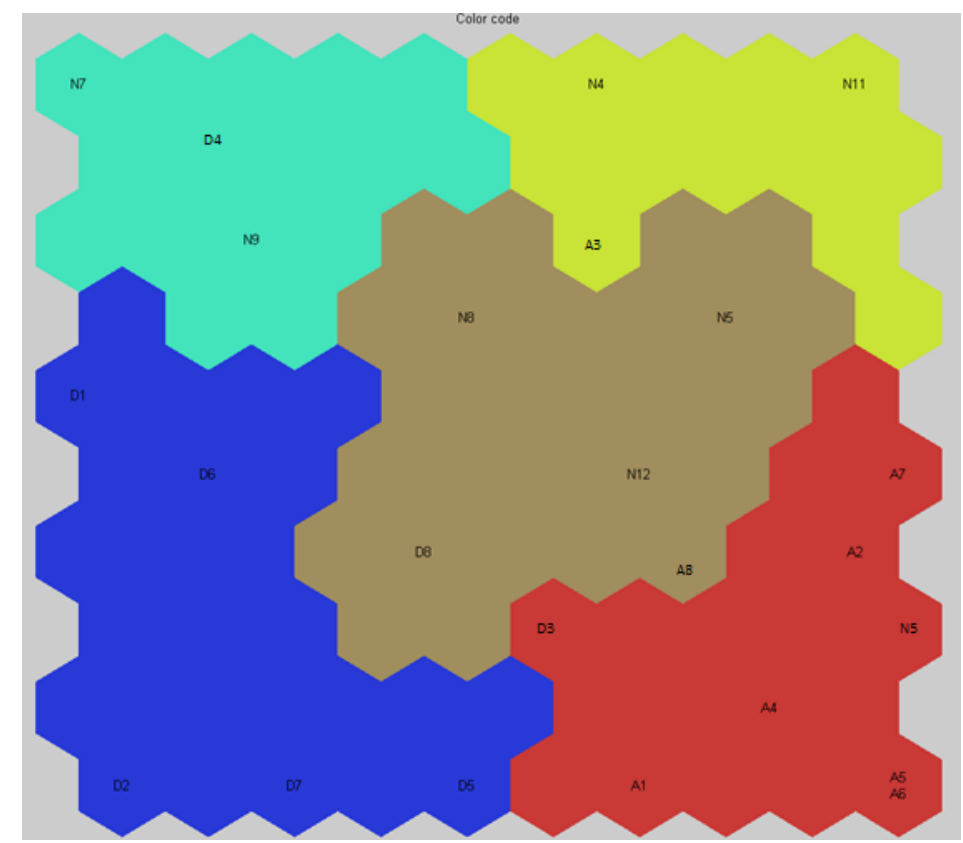

FIGURA 32 - Mapa resultante do segundo teste. A função 'som_clustercolor' foi utilizada para colorir cada um dos agrupamentos com uma cor diferente

TABELA 2 - Composição dos agrupamentos

\begin{tabular}{lccc}
\hline $\begin{array}{c}\text { Cor do } \\
\text { grupo }\end{array}$ & $\begin{array}{c}\text { Rótulos de cromossomos } \\
\text { em anel (\%) }\end{array}$ & $\begin{array}{c}\text { Rótulos de } \\
\text { cromossomos } \\
\text { dicêntricos (\%) }\end{array}$ & $\begin{array}{c}\text { Rótulos de } \\
\text { cromossomos } \\
\text { normais (\%) }\end{array}$ \\
\hline Vermelha & 75 & 12,5 & 12,5 \\
Azul escuro & 0 & 100 & 0 \\
Verde & 33,33 & 0 & 66,66 \\
Marrom & 20 & 20 & 60 \\
Azul claro & 0 & 33,33 & 66,66 \\
\hline
\end{tabular}

Portanto, o grupo representado pela cor vermelha é composto em sua maioria por rótulos de cromossomos em anel; o grupo azul escuro composto apenas por cromossomos dicêntricos; e os 3 grupos restantes são compostos em suas maiorias por cromossomos normais.

$\mathrm{Na}$ tentativa de identificar o que levou o mapa a separar os cromossomos normais em 3 grupos distintos, foi feita uma análise das imagens cromossômicas relacionadas aos rótulos pertencentes a cada um dos grupos. Por meio da qual, foram feitas as seguintes constatações: 
O grupo representado pela cor verde é composto, em sua totalidade, por cromossomos acrocêntricos; o grupo representado pela cor marrom é composto, em sua totalidade, por submetacêntricos; e o grupo representado pela cor azul claro é composto, em sua totalidade, por cromossomos metacêntricos. Ou seja, a rede separou os cromossomos normais em 3 tipos de acordo com o posicionamento dos seus centrômeros.

Portanto, dentre os 5 grupos descritos anteriormente, estão 3 grupos de cromossomos normais, um grupo de dicêntricos, e um grupo de anéis, por meio dos quais é possível identificar os tipos de cromossomos cuja classificação foi proposta nesta metodologia (normal, anel e dicêntrico). Além disso, a formação dos 5 grupos se mostrou algo positivo para o trabalho, pois por meio dos resultados apresentados pela RNA, é possível identificar não somente se um determinado cromossomo é um anel, dicêntrico ou normal; mas no caso de o cromossomo ser normal, é possível identificar também o tipo de normal, de acordo com o posicionamento do centrômero.

Concluiu-se que as Distâncias Horizontais entre Bordas (DHBs) são características relevantes para a classificação dos cromossomos, já que a RNA apresentou os primeiros sinais de discriminação entre os tipos de cromossomos. Entretanto, é necessário realizar alguns ajustes, já que na maioria dos grupos foram identificados cromossomos "intrusos", ou seja, que deveriam pertencer a outro grupo. Os seguintes procedimentos foram realizados com o objetivo de realçar as características de interesse e com isso evitar que cromossomos de mesmo tipo sejam posicionados em agrupamentos distintos.

\subsubsection{Padronização do range (faixa de variação) dos $D H B s$}

Com base na análise do mapa resultante, e dos gráficos dos $D H B s$, observou-se que vetores que apresentassem a mesma quantidade de constrições, nos quais elas se encontrassem distribuídas em posições similares dentro do vetor, deveriam ser classificados como pertencentes à mesma classe. Contudo, alguns vetores que apresentam características semelhantes, acabavam ficando topologicamente distantes no mapa resultante, em razão de uma diferença relacionada ao range dos DHBs.

Neste trabalho, denominou-se range de um $D H B$ ao valor obtido pela diferença (subtração) entre o pico (valor máximo) e o vale (valor mínimo) deste vetor. No exemplo apresentado na Figura 33 A) o valor máximo é 58 e o mínimo é 20, o que resulta em um 
range igual a 38 . Na Figura 33 B) o valor máximo é 15 e o mínimo é 0 , o que resulta em um range igual a 15.

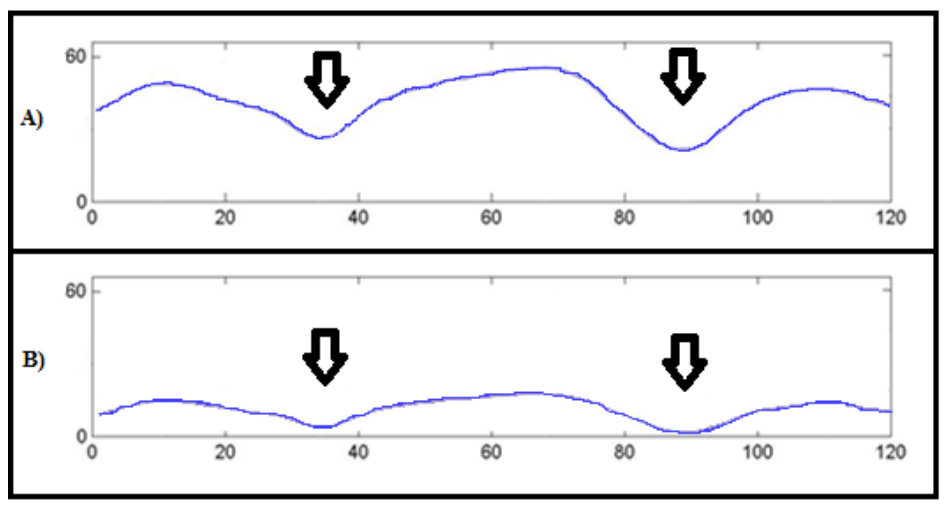

FIGURA 33 - Comparação entre dois gráficos de DHBs cuja amplitude dos ranges é diferente mas a curvatura do gráfico é idêntica. As setas indicam a presença de constrições. Ambos os gráficos foram obtidos a partir de um cromossomo dicêntrico e os ranges foram alterados apenas para ilustrar este exemplo

Na Figura 33, apesar de os gráficos possuírem amplitudes de range diferentes, é possível notar que ambos apresentam a mesma quantidade de constrições, e estas estão distribuídas em posições similares dentro do vetor. Contudo, se estes dois vetores fossem inseridos no SOM, eles ficariam topologicamente distantes no mapa resultante, em razão desta diferença relacionada aos seus ranges.

Portanto, notou-se que o range original dos $D H B s$ não representa uma característica relevante para a classificação dos cromossomos e que ainda faz com que cromossomos de mesmo tipo fiquem distantes no mapa.

Com o objetivo de melhor apresentar a informação referente ao range original dos $D H B s$, e com isso fazer com que eles sejam comparados de forma significativa, foi adotada uma padronização onde o valor mínimo de todos os $D H B$ s passou a valer 0 , e o máximo 100. Para isso as variáveis foram normalizadas através da equação 8:

$$
\operatorname{DHB}(\mathrm{x})=\left(\frac{\mathrm{DHB}(\mathrm{x})-\min (\mathrm{DHB})}{\max (\mathrm{DHB})-\min (\mathrm{DHB})}\right) * 100
$$

onde x representa a posição atual do $D H B$ que deverá ser percorrido por toda a sua extensão; $\min (D H B)$ é o valor mínimo do vetor, $\max (D H B)$ é o valor máximo do $D H B$. 


\subsection{Terceiro teste}

Após a padronização dos ranges dos $D H B$, foi realizado um novo teste para verificar se haveria um aumento no acerto da rede após estas transformações, para que se pudesse fazer uma comparação, foram utilizadas as mesmas 24 imagens cromossômicas empregadas no item 4.2.5.2.1 - Segundo teste. Os procedimentos para criação, inicialização, treinamento configuração e visualização da RNA foram os mesmos descritos no item 4.2.5.1.1 - Primeiro teste. O mapa resultante do terceiro teste, obtido quando foi utilizado o número de agrupamentos igual a 10, é apresentado na Figura 34.

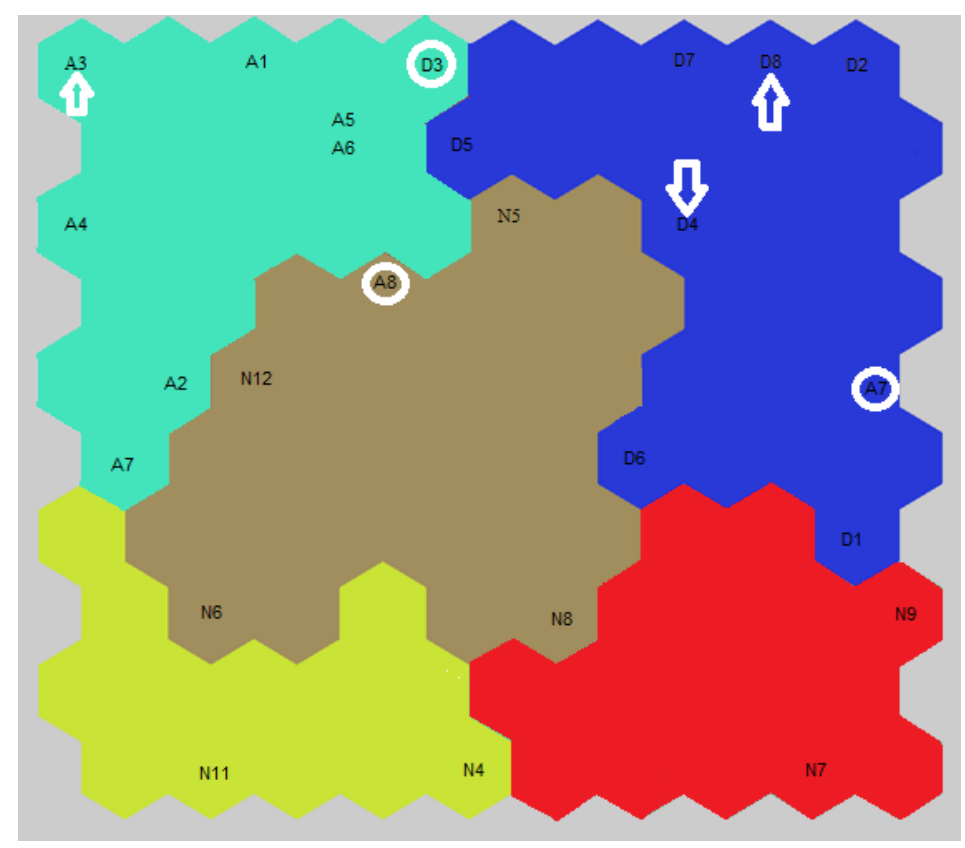

FIGURA 34 - Mapa resultante do terceiro teste. A função 'som_clustercolor' foi utilizada para colorir cada um dos clusters com uma cor diferente

$\mathrm{Na}$ Figura 34, os rótulos dos vetores característicos de cromossomos do tipo anel são iniciados pela letra " $A$ ", os do tipo dicêntrico são iniciados pela letra " $D$ " e os dos cromossomos normais são iniciados pela letra "N". Os rótulos que estão destacados por uma circunferência são referentes a vetores que foram posicionados topologicamente em locais inadequados no mapa, pois destoam da maioria dos componentes do grupo, são eles: D3, A8 e A7. Os rótulos que estão destacados por uma seta, são aqueles que anteriormente estavam incluídos em grupos ao qual não pertenciam (conforme apresentado no item 4.2.5.2.1 - Segundo teste), mas, após a padronização do range, passaram a ser incluídos nos devidos agrupamentos, são eles: D4, A3 e D8. 
Portanto, $50 \%$ dos rótulos que estavam posicionados em locais inadequados, passaram a ser agrupados corretamente, e com isso, pode-se confirmar que às diferenças nos ranges realmente estavam interferindo negativamente na classificação dos cromossomos e que a padronização da faixa de variação dos $D H B s$ é uma transformação importante para a classificação cromossômica.

Por causa dos rótulos que continuaram posicionados em locais indevidos decidiu-se prosseguir com o refinamento do método de extração de características.

\subsubsection{Identificação do limiar e binarização do $D H B$}

Notou-se que havia diferenças significativas na "suavidade das curvas" dos cromossomos e que estas poderiam estar conduzindo a erros na discriminação dos tipos cromossômicos por parte da rede. Um exemplo que ilustra esta problemática é apresentado na Figura 35, na qual, apesar de os dois gráficos representarem características morfológicas de cromossomos dicêntricos, pode-se notar que existem diferenças na "suavidade das curvas": no gráfico B) as curvas são mais suaves do que no gráfico A).

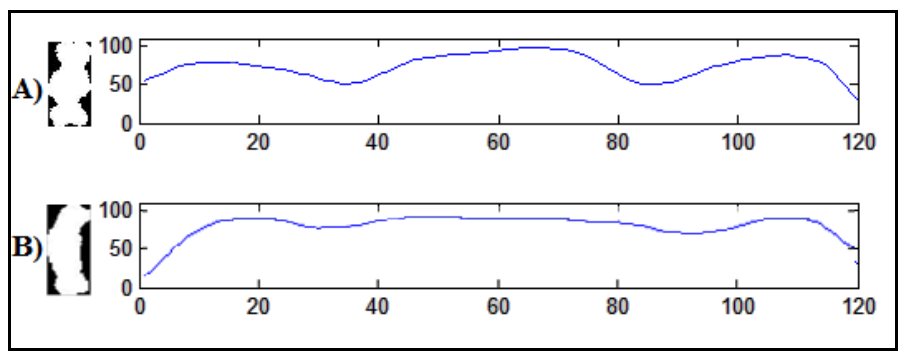

FIGURA 35 - Gráficos de DHBs obtidos a partir de imagens de cromossomos dicêntricos

Com o objetivo de representar apenas a presença ou ausência de constrições significativas no $D H B$, desprezando assim o grau de "suavidade das curvas" o próximo passo foi criar um novo vetor (denominado $D H B 2$ ) que assumisse apenas dois valores: 0 ou 1.

Para isso cada $D H B$ é rastreado, e na medida em que isto é feito, caso o valor do vetor naquela posição seja inferior ao limiar (cujo algoritmo para encontrá-lo será mostrados a seguir) o $D H B 2$ recebe 0 naquela posição, caso contrário recebe 1 . Na Figura 36 são mostrados os gráficos do $D H B$ e do $D H B 2$. 


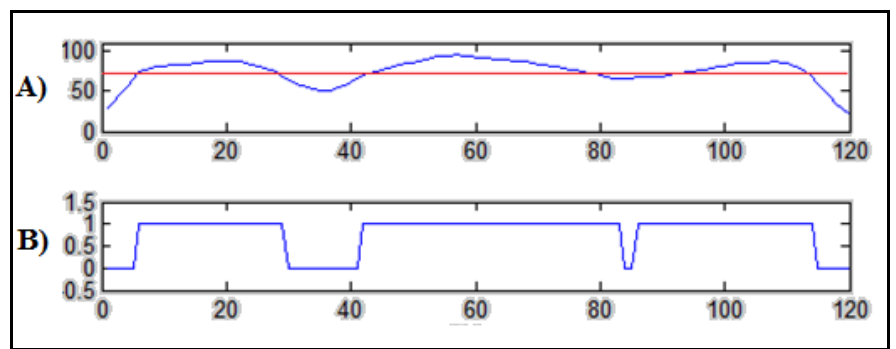

FIGURA 36 - Gráficos obtidos a partir da imagem de cromossomo dicêntrico, o gráfico superior refere-se ao $D H B$, o traço vermelho ilustra o limiar e o segundo gráfico mostra o $D H B 2$

A dificuldade deste procedimento está em identificar o valor do limiar adequado para cada $D H B$, visto que este deve ser "sensível" o bastante para possibilitar que o algoritmo binarizador detecte constrições mais suaves, como as mostradas na Figura 37, mas ao mesmo tempo não deve ser demasiadamente "sensível" ao ponto de fazer com que curvas que não representem centrômeros sejam identificadas, como mostrado na Figura 38.

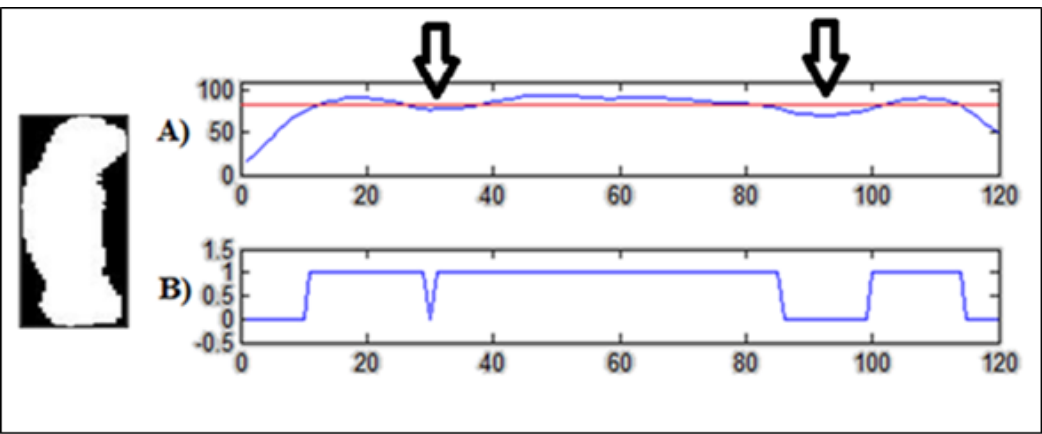

FIGURA 37 - Gráficos obtidos a partir do imagem do cromossomo dicêntrico localizado à esquerda. O gráfico superior refere-se ao $D H B$, o traço vermelho ilustra o limiar e o segundo gráfico mostra o $D H B 2$. As setas indicam constrições suaves que devem ser detectadas

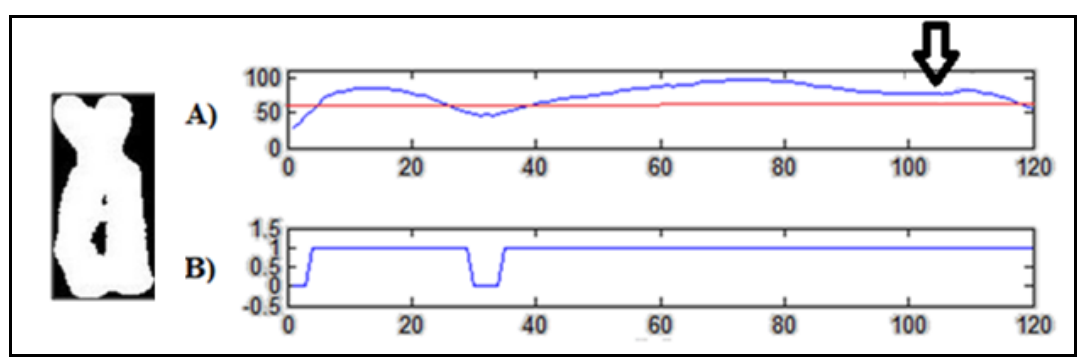

FIGURA 38 - Gráficos obtidos a partir do imagem do cromossomo normal localizado à esquerda $\mathrm{O}$ gráfico superior refere-se ao $D H B$, o traço vermelho ilustra o limiar e o segundo gráfico mostra o $D H B 2$. A seta indica uma constrição suave que não deve ser detectada

Através da análise de gráficos, de forma empírica, foi desenvolvido um algoritmo que calcula um valor de limiar para cada $D H B$, através dos procedimentos mostrados a seguir: 
Primeiramente rastreia-se o $D H B$ nas posições entre 1 e 20 em busca do pico (valor máximo) do $D H B$ no início do vetor. O valor resultante é armazenado na variável maximol e a posição em que ele se encontra é armazenada na variável pos 1 , conforme o algoritmo a seguir:

$[$ maximo1,pos1] $=\max (\operatorname{vetor}(1: 20))$;

Em seguida rastreia-se o $D H B$ nas posições entre 101 e 120 em busca do pico (valor máximo) do $D H B$ no final do vetor. O valor resultante é armazenado na variável maximo2 e a posição em que ele se encontra é armazenada na variável pos2, conforme o algoritmo a seguir:

[maximo2,pos2]=max(vetor $(101: 120))$;

A função acima inicia a contagem da posição em 1, como queremos saber a posição a partir de 101, o ajuste mostrado a seguir é necessário:

$\operatorname{pos} 2=\operatorname{pos} 2+101$

O próximo passo é rastrear o $D H B$ nas posições entre pos1 e 60 a fim de encontrar o vale (valor mínimo) do $D H B$ após o primeiro pico e antes da metade do vetor, este valor é armazenado na variável minimol, conforme o algoritmo a seguir:

[minimo1] $=\min ($ vetor $(\operatorname{pos} 1: 60))$;

Em seguida rastreia-se o $D H B$ nas posições entre 61 e pos 2 em busca do vale do $D H B$ após metade do vetor e antes do último pico. O valor resultante é armazenado na variável minimo2, conforme o algoritmo a seguir:

[minimo2]=min(vetor $(61: \operatorname{pos} 2))$;

Calcula-se então a diferença de altura entre o primeiro vale e o primeiro pico do vetor, conforme o algoritmo a seguir:

deltal = maximo1-minimol;

Calcula-se também a diferença de altura entre o último vale e o ultimo pico do vetor, conforme o algoritmo a seguir:

delta2=maximo2-minimo2; 
Com base nessas informações, o valor do limiar de cada $D H B$ é calculado conforme o algoritmo a seguir:

se $($ delta1 $>12)$ e (delta2 $>12)$

senão

limiar $=\max ($ minimo1, minimo2 $)+0.5$;

$\operatorname{minimo}=\min ($ vetor $(\operatorname{pos} 1: \operatorname{pos} 2))$;

limiar=minimo +3 ;

fim se

$\mathrm{O}$ que significa que se ambas as diferenças de alturas forem maiores que $12 \mathrm{o}$ limiar será pouco $(0,5)$ maior do que o valor do vale mais alto. Senão o limiar corresponderá ao valor mínimo entre pos1 e pos 2 acrescido de 3.

Antes de se realizar um novo teste na RNA, por meio da análise dos gráficos dos $D H B 2$, identificou-se a necessidade de se realizar uma redistribuição nas bandas, conforme descrito no item a seguir.

\subsubsection{Redistribuição das bandas}

Neste trabalho, uma banda é caracterizada por um agrupamento de 'uns' dentro do $D H B 2$. O comprimento da banda é obtido pela contagem de valores subsequentes iguais a 1 no vetor analisado, com a contagem cessando quando a busca encontra o valor 0 . Em seguida, a busca pelo vetor continua e, caso outro valor igual a 1 seja encontrado, inicia-se a contagem para uma nova banda. Conforme ilustrado na Figura 39.

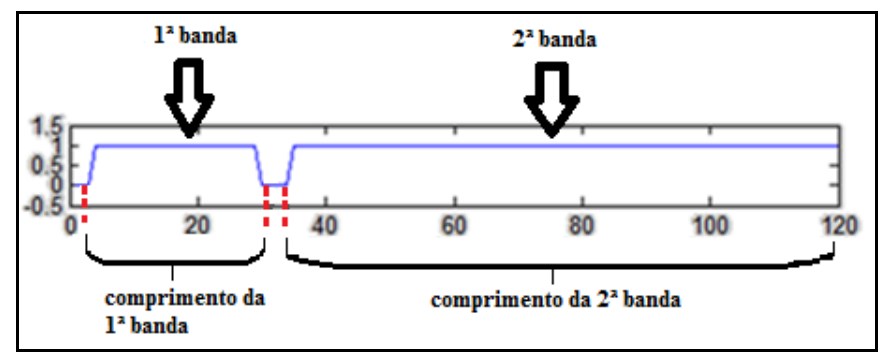

FIGURA 39 - Ilustração das bandas no DHB2

Para explicar a importância de se realizar ajustes na distribuição das bandas dentro do vetor a ser inserido na RNA, será feita uma breve descrição de como é feito, internamente pelo SOM, o cálculo da distância Euclidiana, utilizada para quantificar as semelhanças entre os vetores da RNA. 
Ao apresentar um vetor de características para a entrada da RNA é feita uma comparação entre este vetor e cada um dos seus vetores de protótipos (pesos das redes auto-organizáveis) com o objetivo de encontrar aquele que apresente características mais próximas ao vetor de entrada. Para isso, uma das funções de distância mais empregada é a distância Euclidiana, que já foi definida anteriormente neste trabalho pela equação 2:

$$
D_{E}=\sqrt{\left(x_{1}-y_{1}\right)^{2}+\left(x_{2}-y_{2}\right)^{2}+\cdots+\left(x_{n}-y_{n}\right)^{2}}
$$

onde $x_{n}$ são as coordenadas dos vetores de entrada e $y_{n}$ são as coordenas dos vetores protótipo (pesos das redes auto-organizáveis).

Na Figura 40 é ilustrado o que acontece quando um $D H B 2$ é apresentado à RNA. O primeiro gráfico apresenta um $D H B 2$ de um cromossomo normal do tipo metacêntrico. O segundo gráfico apresenta um vetor de protótipos criado apenas para auxiliar esta explicação. O terceiro gráfico apresenta o vetor D que armazena as distâncias de cada posição da seguinte maneira: calcula-se a diferença entre o valor da primeira posição do vetor de entrada e o valor primeira posição do vetor de protótipo e eleva-se ao quadrado (neste exemplo ficaria $\left((0-1)^{2}\right)$. O resultado é armazenado na primeira posição do vetor $\mathrm{D}$, em seguida o procedimento é repetido para a segunda posição dos vetores e assim sucessivamente até o final das 120 variáveis. Posteriormente é feita a soma dos valores de cada posição do vetor $\mathrm{D}$ e então é extraída a raiz quadrada desta soma. O procedimento é repetido para os demais protótipos do mapa.

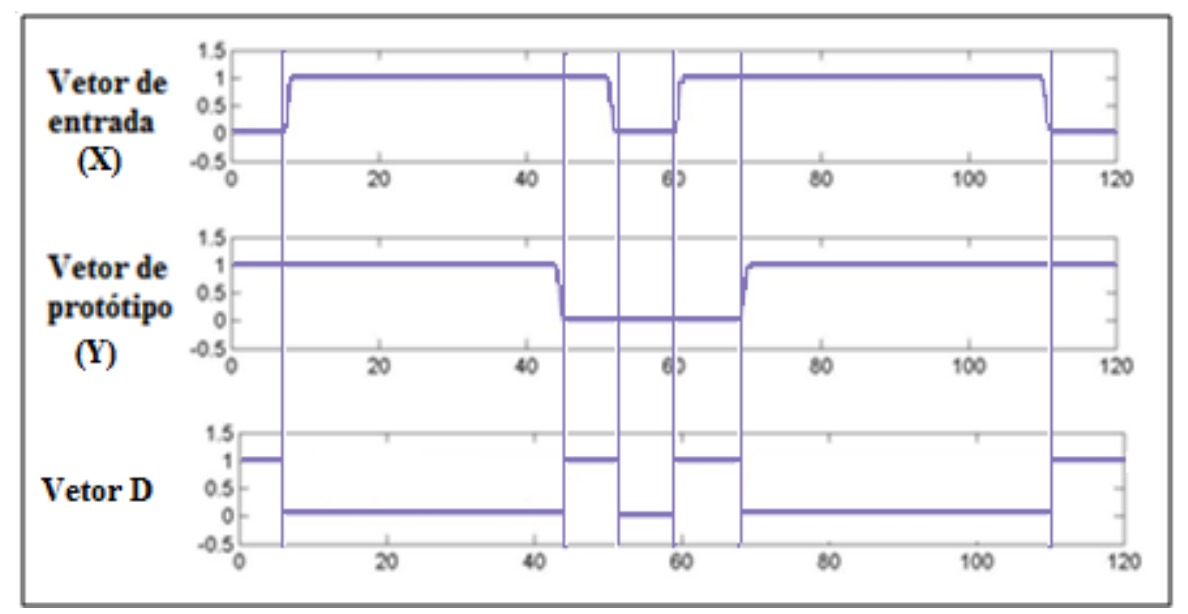

FIGURA 40 - Representação do cálculo de distâncias entre um vetor de entrada e um vetor de protótipo de um mapa auto-organizável. 
$\mathrm{Na}$ Figura 40 o vetor de entrada e o vetor de protótipos apresentam a mesma quantidade de bandas, além disso o comprimento da primeira banda do vetor de entrada é igual ao comprimento da primeira banda do vetor de protótipo, e o comprimento da segunda banda do vetor de entrada é igual ao comprimento da segunda banda do vetor de protótipo.

Entretanto, apesar de serem iguais em relação a esses quesitos, que são importantes para a classificação cromossômica, o resultado do cálculo de distâncias Euclidianas revelou diferenças significativas entre os dois vetores. Isto ocorre por causa do posicionamento em que suas bandas se encontram. A forma como é feito o cálculo das distâncias entre os vetores de entrada e os vetores de protótipos faz com que o posicionamento efetivo da banda adquira uma importância maior do que a necessária para a classificação correta do cromossomo.

Com o objetivo de fazer com que os vetores que carregam informações de cromossomos de mesmo tipo fiquem mais parecidos entre si, sem que com isso sejam perdidas as informações importantes para a classificação correta, foi adotada uma padronização da distribuição das bandas, tarefa que foi realizada de acordo com os seguintes procedimentos.

\subsection{Redistribuição de $D H B 2 s$ com uma ou duas bandas}

Os DHB2s que apresentam apenas uma banda são provenientes de cromossomos com aberração anelar, caso a banda esteja próximo a uma das extremidades do vetor. Caso a banda esteja próxima ao centro do vetor, trata-se de um acrocêntrico, conforme apresentado na Figura 41.

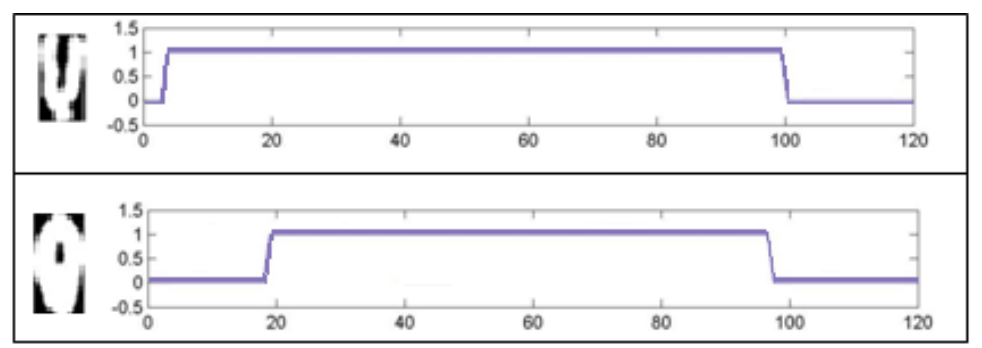

FIGURA 41 - Gráficos de $D H B 2 s$ que apresentam uma banda. O gráfico da figura superior corresponde a um cromossomo do tipo acrocêntrico e o gráfico da figura inferior corresponde a um cromossomo do tipo anel

Para evitar que o braço curto presente em algumas das imagens de cromossomos acrocêntricos faça com que eles sejam discriminados em classe diferente dos 
demais cromossomos acrocêntricos que não apresentam o braço curto e também para evitar que possíveis ruídos nas imagens sejam identificados como banda, adotou-se que uma banda somente será válida se o comprimento for maior ou igual a 5. Com esta medida, todos gráficos provenientes dos cromossomos acrocêntricos passam a apresentar apenas uma banda.

Os $D H B 2 s$ que apresentam duas bandas são provenientes de cromossomos normais do tipo metacêntrico ou normais do tipo submetacêntrico. Caso as duas bandas sejam aproximadamente do mesmo comprimento, trata-se de um cromossomo metacêntrico, caso sejam de tamanhos diferentes, trata-se de um submetacêntrico, conforme apresentado na Figura 42.

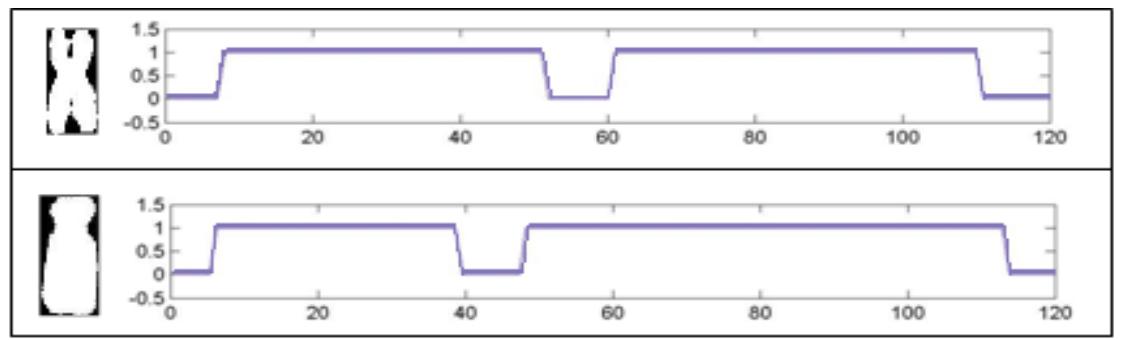

FIGURA 42 - Gráficos de $D H B 2 s$ que apresentam duas bandas. O gráfico da figura superior corresponde a um cromossomo normal do tipo metacêntrico e o gráfico da figura inferior corresponde a um cromossomo normal do tipo submetacêntrico

Para isso, faz-se a soma dos elementos das colunas da primeira metade do vetor (índices de 1 a 60), e armazena-se em uma variável denominada somal, em seguida faz-se a soma dos valores na segunda metade do vetor (índices de 61 a 120), e armazena-se na variável soma2. Se a primeira soma (somal) for maior que a segunda (soma2), a variável denominada vetor_redistribuido recebe o conteúdo do DHB2 invertido (de traz para frente) através da função 'wrev' do Wavelet Toolbox do Matlab ${ }^{\circledR}$, senão vetor_redistribuido recebe o próprio $D H B 2$, conforme o algoritmo a seguir:

$\operatorname{somal}=\operatorname{sum}(\operatorname{DHB2}(1: 60))$;

$\operatorname{soma2}=\operatorname{sum}(\operatorname{DHB2}(61: 120))$;

se (somal>soma2)

vetor_redistribuido $=w r e v(D H B 2) ;($ Obtêm-se o inverso do vetor $)$

senão

vetor_redistribuido=DHB2;

fim se 
Na Figura 43 são mostrados os gráficos, referentes a dois cromossomos normais, resultantes da redistribuição das bandas.

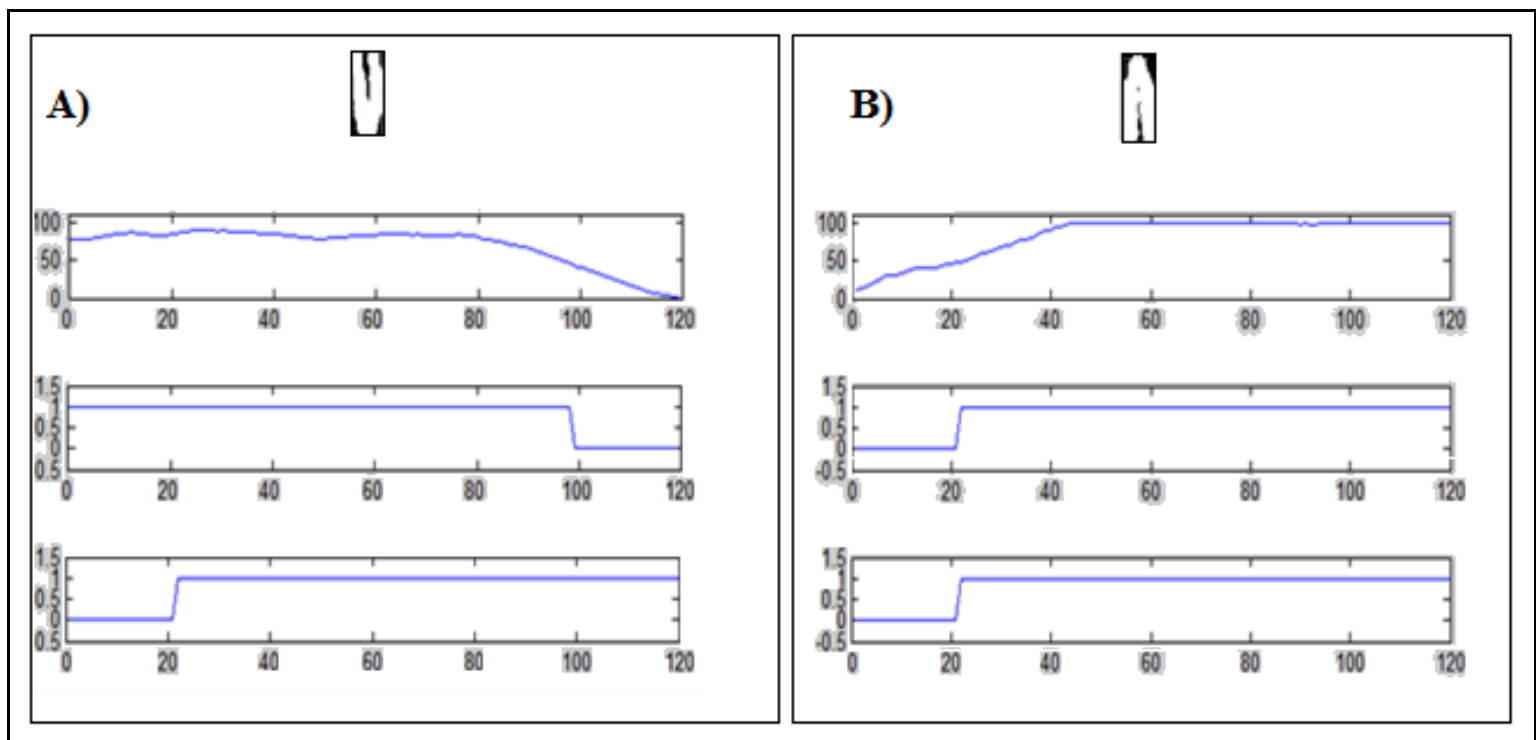

FIGURA 43 - Tanto os gráficos em A) representados a esquerda, quanto os gráficos em B) correspondem a imagens de cromossomos acrocêntricos. Os gráficos superiores correspondem aos $D H B s$, os gráficos centrais correspondem aos $D H B 2 s$, e os gráficos inferiores correspondem aos vetores redistribuídos

Em $D H B 2 s$ que apresentam uma ou duas bandas, verifica-se a existência de bandas cuja distância, em relação ao índice 0 do vetor, seja menor que 15 , neste caso a banda é reposicionada para o início do vetor. Em seguida verifica-se a existência de uma banda cuja distância em relação ao índice 120 do vetor seja menor que 15 , caso isso ocorra a banda é reposicionada para o final do vetor, conforme apresentado na Figura 44.

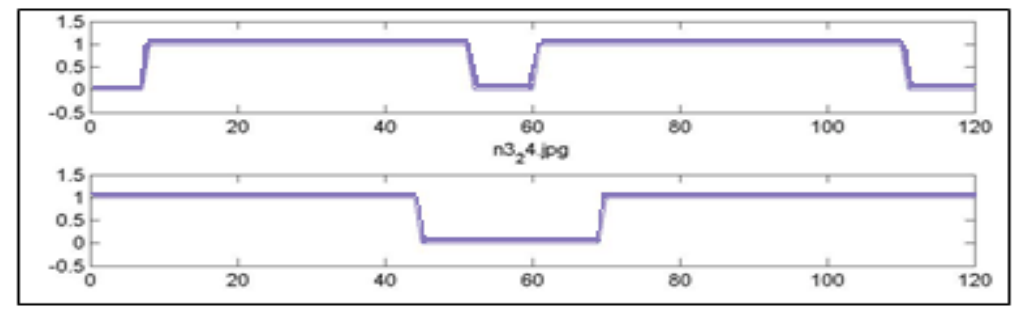

FIGURA 44 - Gráficos obtidos a partir da imagem de um cromossomo normal metacêntrico. O gráfico superior refere-se ao DHB2 e o inferior refere-se ao vetor redistribuído.

\subsection{Redistribuição de $D H B 2 s$ com três bandas}

Todos os DHB2s que apresentam três bandas são provenientes de cromossomos com aberração do tipo dicêntrico. Neste caso, como existe apenas uma possibilidade de classificação, a informação referente ao posicionamento e comprimento 
de cada banda não auxiliam na classificação e portanto não precisam serem preservadas. Em $D H B 2 s$ com três bandas, o ajuste é realizado com o objetivo de fazer com que fiquem o mais diferente possível dos DHB2s que apresentam uma ou duas bandas. Neste procedimento é feita uma soma dos comprimentos das bandas, em seguida é subtraído o valor 9 deste total, por último o valor resultante é dividido em 3, para que formem 3 bandas de comprimentos iguais de modo que uma delas é posicionada no início do vetor, outra no meio e outra no final. Na Figura 45 é mostrada a redistribuição realizada em gráficos que correspondem a imagens de cromossomos dicêntricos.

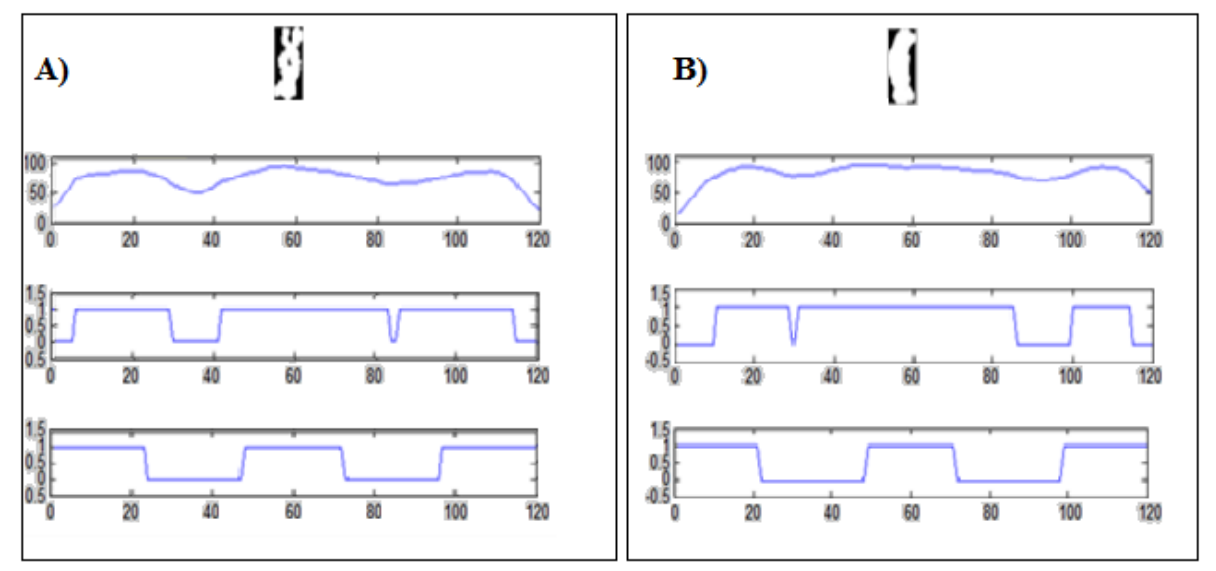

FIGURA 45 - Os gráficos obtidos correspondem a imagens de cromossomos dicêntricos, os gráficos superiores correspondem aos $D H B s$, os gráficos centrais correspondem aos $D H B 2 s$, e os gráficos inferiores correspondem aos vetores redistribuídos

Após a redistribuição das bandas, foi realizado um novo teste na RNA no qual o objetivo do treinamento foi alcançado, pois cada cluster formado no mapa é composto somente por rótulos de um mesmo tipo cromossômico. Este teste é descrito em detalhes na próxima seção por fazer parte dos resultados finais deste trabalho. 


\section{RESULTADOS E DISCUSSÕES}

Neste trabalho, ao inserir as intensidades de pixels das imagens diretamente na rede neural auto-organizável (sem que primeiramente fosse aplicado qualquer método de extração de características), as propriedades relevantes para classificação não se apresentaram evidentes o suficiente para serem representadas pelos protótipos do mapa, impedindo que a rede discriminasse os tipos cromossômicos.

A interpretação direta dos dados não foi possível basicamente por dois motivos: em virtude da expressiva irregularidade na morfologia dos cromossomos, e levando-se em conta o número limitado de cromossomos aberrantes presente na base de dados deste trabalho. Para realçar as informações relevantes para classificação, foi desenvolvido um método de extração de características, cujas etapas envolvidas estão apresentadas na Figura 46.

O método aqui proposto se constitui de cinco etapas: 1) redimensionamento da imagem 2) cálculo das distâncias horizontais entre as bordas de cada imagem cromossômica (DHBs); 3) padronização do range (faixa de variação) dos $D H B s ; 4)$ identificação do limiar e binarização do vetor, e 5) redistribuição das bandas.

Os vetores resultantes desta metodologia carregam três características fundamentais para a discriminação dos tipos de cromossomos: a quantidade de bandas, o comprimento e o posicionamento de cada uma delas dentro do vetor. 
1) Redimensionamento da imagem

2)

Calculo das distancias horizontais entre bordas

3) Padronização do range
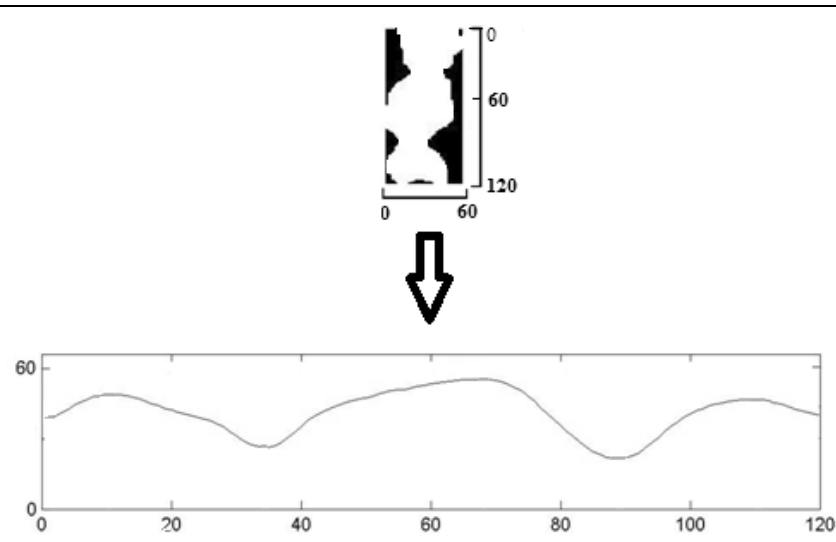

§

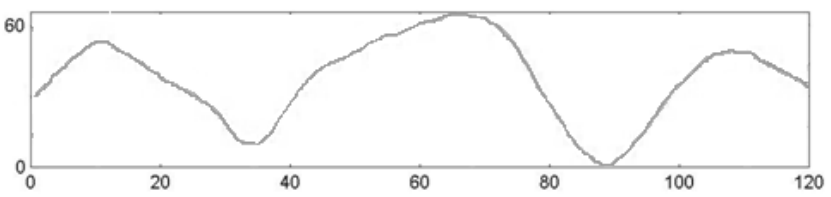

凤

4). Identificação do limiar e binarização do vetor
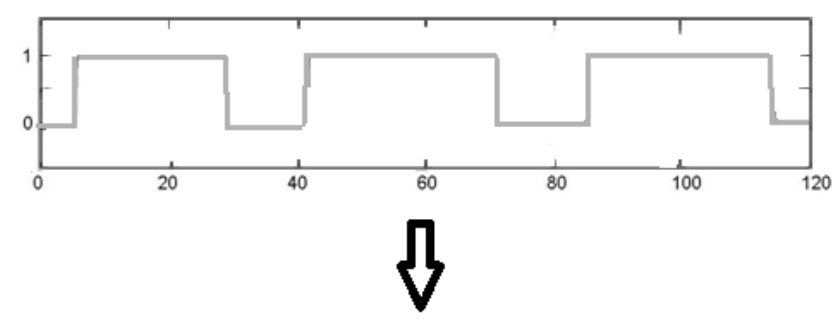

5) Redistribuição das bandas

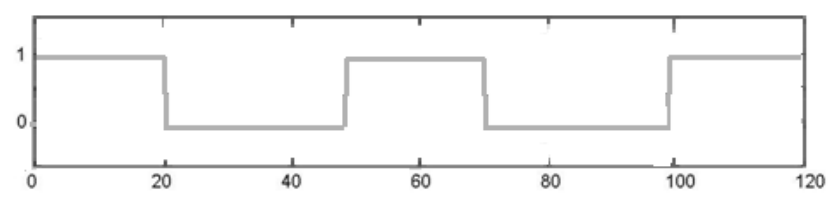

FIGURA 46 - Diagrama de sequência de transformações ao qual a imagem cromossômica redimensionada é submetida para se obter o vetor característico a ser inserido no SOM, estas etapas constituem o método de extração de características proposto neste trabalho

\subsection{Conjunto de dados utilizados para obtenção do resultado final}

Durante a fase de treinamento da RNA, foram utilizados os vetores de características referentes aos seguintes tipos de cromossomos: 4 cromossomos em anel, 4 dicêntricos, e 12 normais (4 acrocêntricos, 4 submetacêntricos, 4 metacêntricos), totalizando 20 cromossomos, conforme Figuras 47, 48, 49, 50 e 51: 


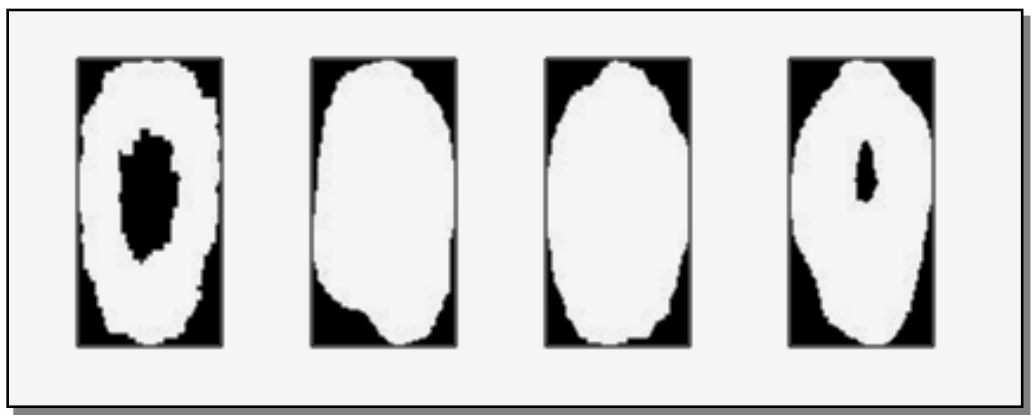

FIGURA 47 - Imagens segmentadas e reposicionadas de cromossomos com aberração do tipo anel usadas no treinamento da rede neural artificial desenvolvida neste trabalho

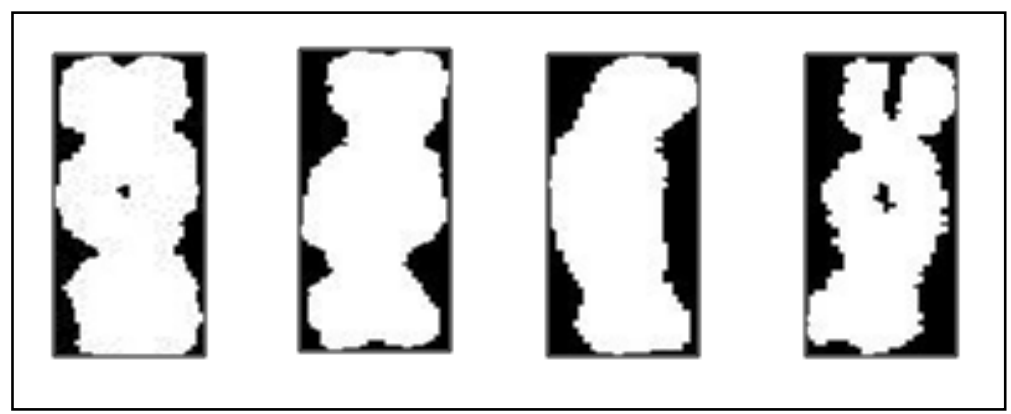

FIGURA 48 - Imagens segmentadas e reposicionadas de cromossomos do tipo dicêntrico usadas no treinamento da rede neural artificial desenvolvida neste trabalho

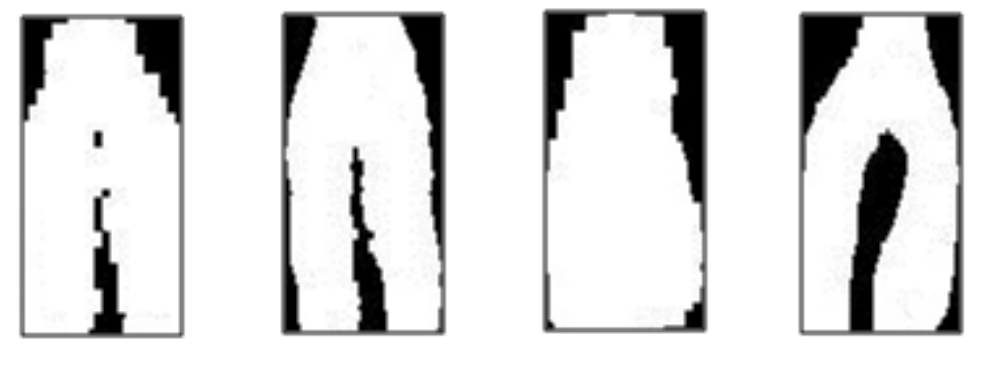

FIGURA 49 - Imagens segmentadas e reposicionadas de cromossomo do tipo acrocêntrico, usadas no treinamento da rede neural artificial desenvolvida neste trabalho

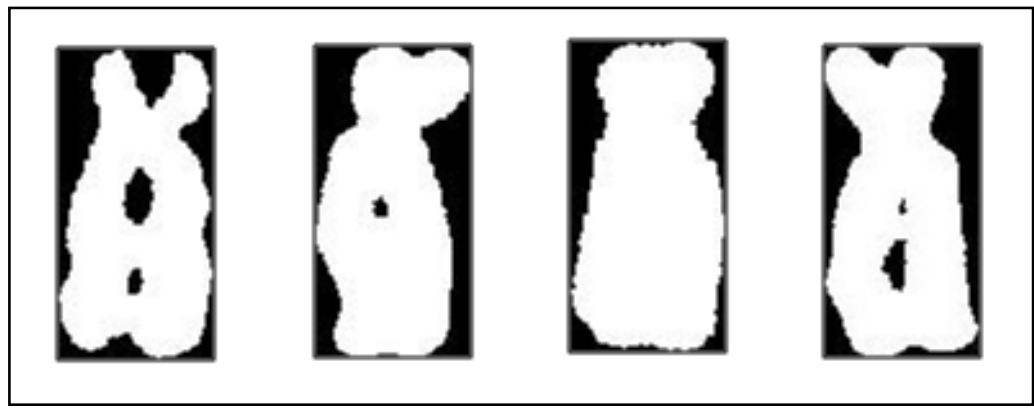

FIGURA 50 - Imagens segmentadas e reposicionadas de cromossomos s do tipo submetacêntrico, usadas no treinamento da rede neural artificial desenvolvida neste trabalho 


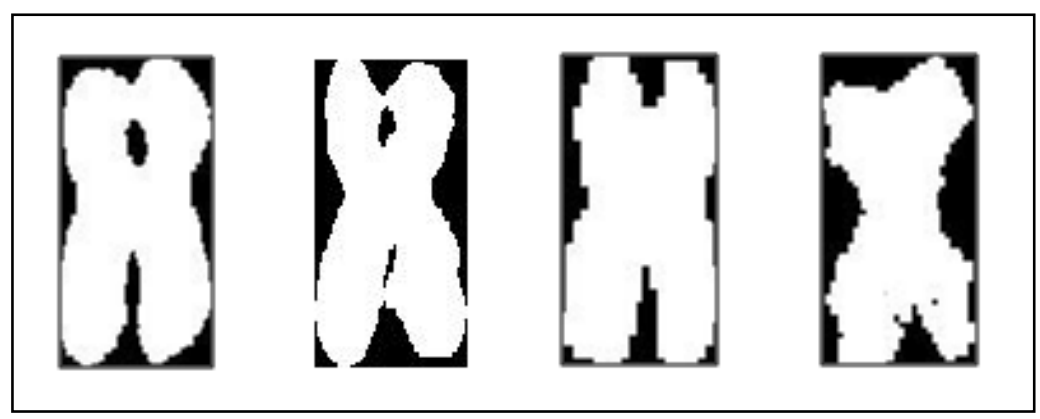

FIGURA 51 - Imagens segmentadas e reposicionadas de cromossomos do tipo metacêntrico, usadas no treinamento da rede neural artificial desenvolvida neste trabalho

Durante a fase de validação, foram utilizados os vetores de características referentes aos seguintes tipos de cromossomos: 8 cromossomos em anel, 13 dicêntricos, e 479 cromossomos normais, sendo 84 acrocêntricos, 305 submetacêntricos e 90 metacêntricos, totalizando 500 imagens cromossômicas (contando com as imagens usadas no treinamento).

\subsection{Configuração final da RNA}

De forma empírica, buscou-se a configuração do mapa que apresentasse menor valor de erro de quantização médio (qe) e erro topográfico (te). O melhor resultado obtido foi qe $=0.2303$ e te $=0$. Na Tab. 3 são apresentados os parâmetros utilizados:

TABELA 3 - Parâmetros usados na configuração da RNA

\begin{tabular}{cc}
\hline Parâmetros & Valores \\
\hline Tamanho do mapa & $10 \times 10$ \\
$\sigma 1$ & 6 \\
$\sigma 2$ & 2 \\
$\alpha 1$ & 0,5 \\
$\alpha 2$ & 0,05
\end{tabular}

O parâmetro $\sigma 1$ é referente ao raio na fase inicial, e o $\sigma 2$ é referente ao raio na fase de ajuste fino. A taxa de aprendizagem foi de $\alpha 1$ e $\alpha 2$ respectivamente.

A configuração adotada foi: Lattice hexagonal, formato de folha (sheet), inicialização randômica e treinamento sequencial. Treinamento realizado em duas fases: inicialmente com grande vizinhança e alta taxa de aprendizagem; e posteriormente uma 
fase de ajuste fino com largura inicial pequena e baixa taxa de aprendizagem, cada uma das fases com 5000 iterações.

A seguinte fórmula heurística foi usada para calcular a quantidade de unidades de um mapa de tamanho médio: munits $=5 \mathrm{X}$ dlen $^{0,54321}$, onde dlen representa a quantidade de amostras no mapa. Neste trabalho foram usadas 20 amostras, portanto o número de unidades seria aproximadamente 25. Foram realizados testes com mapas de tamanho pequeno, médio e grande, e os melhores resultados foram obtidos ao se utilizar o mapa de tamanho grande (com tamanho igual a 4 vezes a quantidade de unidades do mapa de tamanho médio). Por este motivo foi utilizado um mapa com cem unidades, distribuídas em 10 linhas e 10 colunas.

\subsection{Visualizações dos resultados}

Para a visualização do mapa formado após o treinamento, a função 'som_umat' foi utilizada. A Figura 52 mostra a matriz de distâncias unificada (U-matrix) obtida.

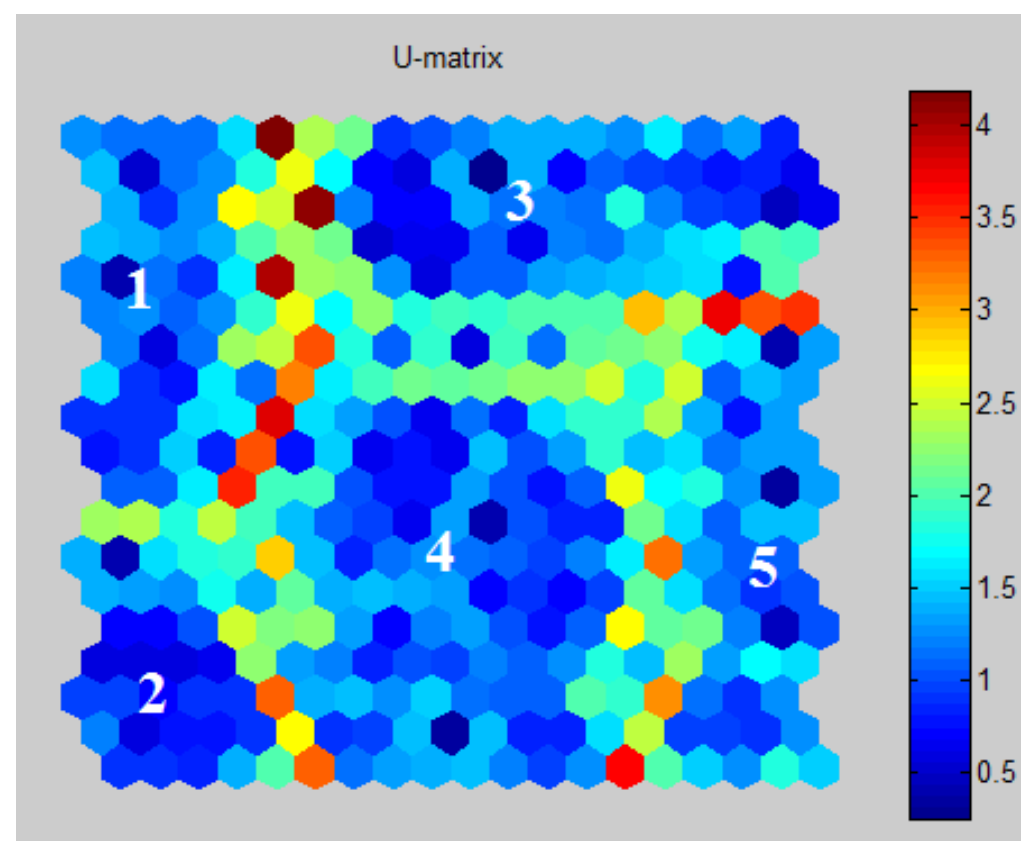

FIGURA 52 - Matriz de distâncias unificada (U-matrix) obtida após o treinamento da RNA. Nesta figura os clusters estão destacados pelos números de 1 a 5

Na Figura 52, os valores altos da legenda de distâncias (acima de dois), representados pelas cores verde, amarelo e vermelho, indicam a borda dos clusters, e a cor azul (abaixo de dois) representa os neurônios mais próximos, ou seja, os próprios 
agrupamentos. Portanto, ao analisar o mapa, fica evidente a formação de 5 grupos (clusters 1, 2, 3, 4 e 5 destacados nesta figura).

As unidades do mapa foram coloridas, de acordo com o cluster ao qual pertencem, e o resultado obtido é apresentado na Figura 53.

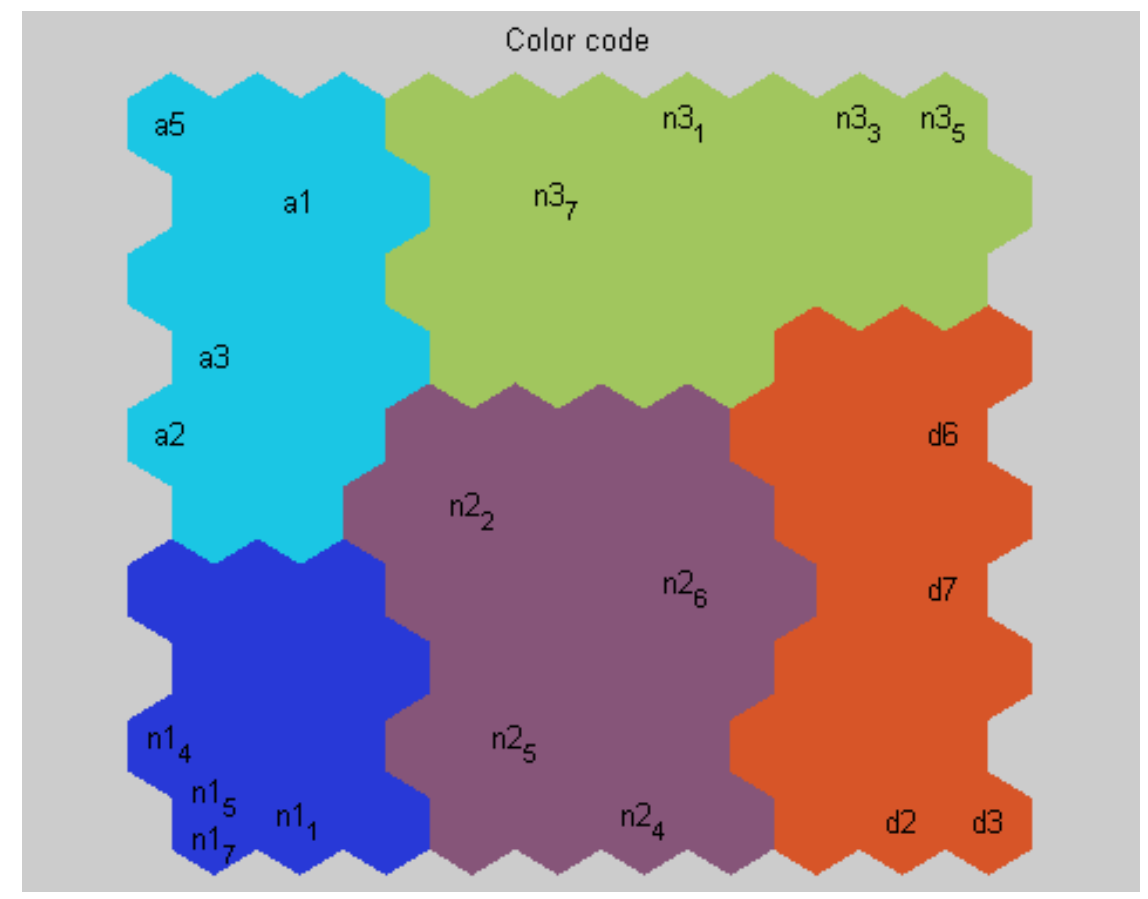

FIGURA 53 - Mapa formado após o treinamento da RNA. A função 'som_clustercolor' foi utilizada para colorir cada um dos clusters com uma cor diferente

Na Figura 53, cada rótulo está posicionado na unidade do mapa em que se encontra o protótipo mais parecido com o vetor característico que ele representa (ou seja, a BMU). Os vetores que possuem as características de cromossomos do tipo anel são representados pelos rótulos iniciados pela letra "a", os do tipo dicêntrico são representados pelos rótulos iniciado pela letra "d", os do tipo acrocêntrico são representados pelos rótulos iniciados pela letra " $n$ " seguida do número “1”, os do tipo submetacêntrico são representados pelos rótulos iniciados pela letra "n" seguida do número "2", os do tipo metacêntricos são representados pelos rótulos iniciados pela letra " $n$ " seguida do número "3".

A partir da visualização do mapa é possível verificar que os rótulos de cromossomos do mesmo tipo ficaram topologicamente próximas no mapa, e que cada cluster é composto exclusivamente por rótulos de um tipo de cromossomo, não havendo rótulos "intrusos" (que deveriam pertencer a outro grupo) em nenhum dos 5 clusters. Este 
foi um indicativo de que a partir do método de extração de características aqui proposto, a RNA identificou padrões que permitem classificá-los corretamente.

Utilizou-se a função 'som_plotplane' para visualizar os vetores de protótipos de cada unidade do mapa, os resultados obtidos são apresentados na Figura 54.

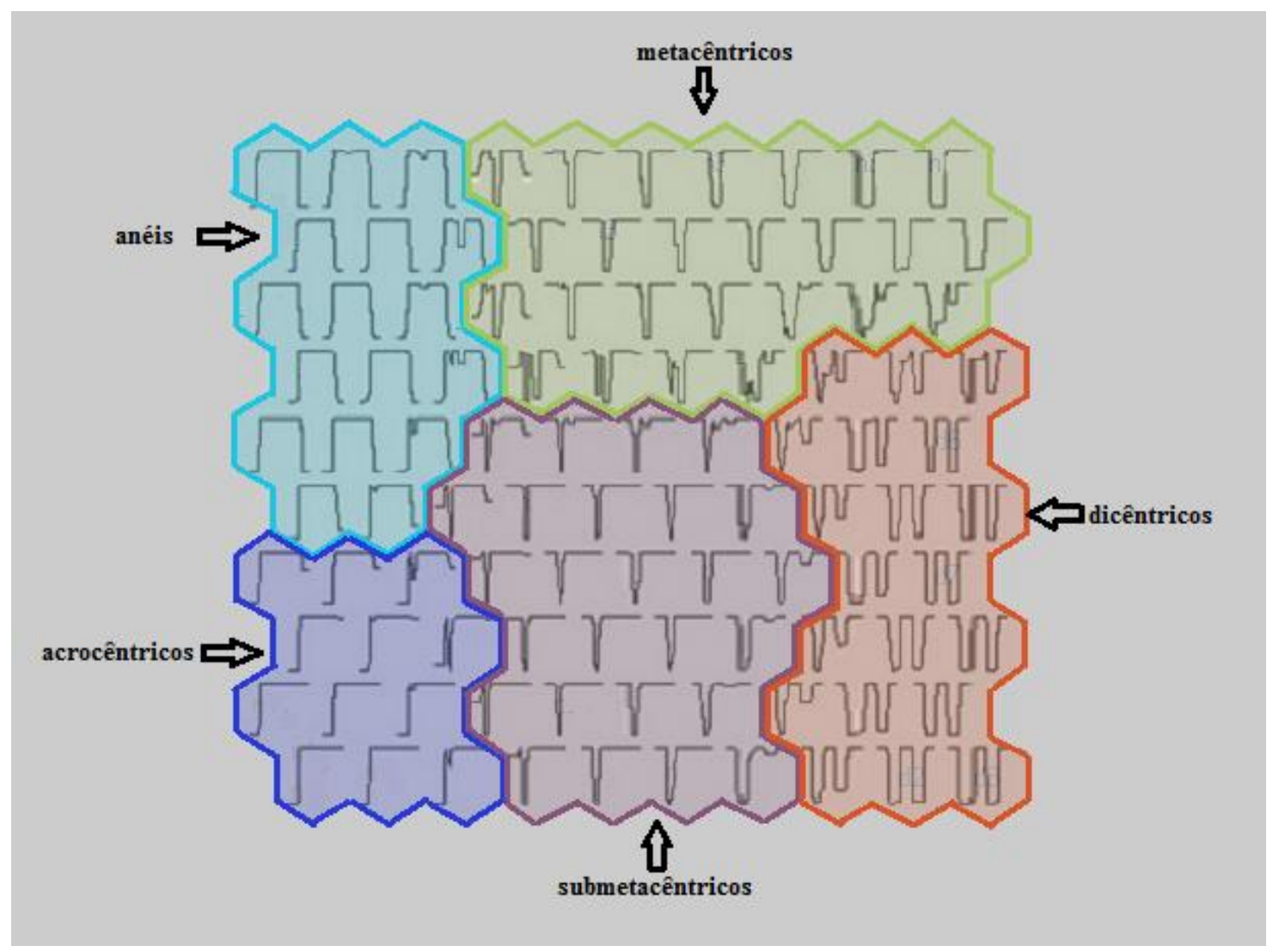

FIGURA 54 - Visualização dos gráficos de vetores de protótipos para cada unidade do mapa. Os valores armazenados no codebook são mostrados seguindo a distribuição topológica do mapa

Os gráficos de vetores de protótipos apresentados na Figura 54 seguem a mesma distribuição topológica do mapa apresentado na Figura 53. Os rótulos dos cromossomos do tipo anel pertencem ao grupo representado pela cor azul claro, os do tipo dicêntrico pertencem ao grupo representado pela cor laranja, e os cromossomos normais pertencem aos outros três grupos restantes.

Ao analisar a Figura 54, é possível observar que em cada grupo, as seguintes características são predominantes: no grupo dos anéis, a maioria dos protótipos apresenta apenas uma banda, localizada no centro do vetor; no grupo dos acrocêntricos, a maioria dos protótipos apresentam apenas uma banda, localizada no final do vetor; no grupo dos submetacêntricos a maioria dos protótipos apresentam duas bandas, de modo que a de 
menor comprimento é localizada no início do vetor, e a de maior comprimento é localizada no final do vetor; no grupo dos metacêntricos a maioria dos protótipos apresentam duas bandas, cujos comprimentos são similares; e por último, no grupo dos dicêntricos a maioria dos protótipos apresentam três bandas. Isto indica que, durante o treinamento, a RNA aprendeu o padrão de distribuição de bandas que foi adotado nesta metodologia.

Para a validação do mapa, através da função 'som_bmus', encontrou-se a melhor unidade correspondente (BMU) de cada um dos vetores de características de 500 imagens de cromossomos individualizados. Em seguida verificou-se a qual cluster cada BMU pertencia e, através do rótulo do cromossomo, se ela pertencia ao cluster correto. Os resultados encontrados estão apresentados na TAB. 4.

TABELA 4 - Resultados apresentados pela RNA na classificação de cromossomos

\begin{tabular}{lcc}
\hline \multicolumn{1}{c}{ Classificação } & $\begin{array}{c}\text { incluindo imagens } \\
\text { sadas no treinamento }\end{array}$ & $\begin{array}{c}\text { excluindo imagens } \\
\text { usadas no treinamento }\end{array}$ \\
\hline Anéis classificados como anel & 8 & 4 \\
Anéis classificados como normais & 0 & 0 \\
Anéis classificados como dicêntricos & 0 & 0 \\
Total de anéis & 8 & 4 \\
Taxa de acerto de anéis & $\mathbf{1 0 0} \%$ & $\mathbf{1 0 0} \%$ \\
Dicêntricos classificados como dicêntrico & 12 & 8 \\
Dicêntricos classificados como anel & 0 & 0 \\
Dicêntricos classificados como normal & 1 & 9 \\
Total de dicêntricos & 13 & $\mathbf{8 8 , 8 8 ~ \%}$ \\
Taxa de acerto de dicêntricos & $\mathbf{9 2 , 3 0 \%}$ & 435 \\
Normais classificados como normal & 447 & 11 \\
Normais classificados como anel & 11 & 21 \\
Normais classificados como dicêntrico & 21 & 467 \\
Total de normais & 479 & $\mathbf{9 3 , 1 4 \%}$ \\
Taxa de acerto de normais & $\mathbf{9 3 , 3 1 \%}$ & 480 \\
Total de cromossomos analisados & 500 & 447 \\
Cromossomos classificados corretamente & 467 & 33 \\
Cromossomos classificados erroneamente & 33 & $\mathbf{9 3 , 1 2 5} \%$ \\
Taxa de acerto total & $\mathbf{9 3 , 4} \%$ & \\
\hline
\end{tabular}


De um total de 500 imagens de cromossomos individualizados, 467 apresentaram classificação igual ao diagnóstico dado pelo profissional citogeneticista, e, portanto foram classificadas corretamente pela rede, apresentando uma taxa de acerto de 93,4\%; e 33 imagens foram classificadas pela rede como um tipo de cromossomo diferente do diagnóstico dado pelo especialista, e, portanto representam uma taxa de erro de 6,6\% na classificação automática. A seguir é feita uma análise a respeito dos erros obtidos.

Observou-se que todos os 33 erros estão relacionado a problemas na detecção do centrômero: em 36,36\% das imagens os estreitamentos que revelam a presença de centrômero não foram identificados; e em 63,63\% foram identificados estreitamentos que não revelam a presença de centrômeros.

Além disso, em 63,63\% das imagens classificadas erroneamente notou-se que, em virtude da má qualidade da imagem obtida após a etapa de segmentação, é impossível a distinção visual dos estreitamentos que revelam, ou não, a presença de centrômeros. Portanto, como não houve preservação das características essenciais para a classificação, as falhas ocorreram em razão das etapas de pré-processamento e segmentação.

Em 33,33\% das imagens classificadas erroneamente verificou-se que a disposição dos cromossomos não se encontra adequada para interpretação das características através do algoritmo proposto, que depende do "alinhamento" dos braços dos cromossomos para a classificação correta. Indicando que as falhas ocorreram em razão da etapa de registro.

Em 3\% das imagens classificadas erroneamente, constatou-se que o erro ocorreu em virtude do método de extração de características proposto neste trabalho. Tratase de um cromossomo dicêntrico que foi classificado como normal. Nesta imagem a identificação visual dos dois centrômeros é possível, e o posicionamento dos braços encontra-se relativamente alinhado, mas, apesar das condições favoráveis, 1 dos centrômeros não foi identificado. A falha ocorreu em razão da etapa de identificação do limiar e binarização do vetor $D H B$, que tem como objetivo representar a presença ou ausência de constrições significativas no $D H B$, desprezando assim o grau de "suavidade das curvas". Para isso, com base em um limiar, o vetor resultante assume apenas dois valores: 0 ou 1. Na imagem em que ocorreu o erro, o algoritmo que calcula o limiar determinou um valor acima do adequado, impossibilitando que o algoritmo binarizador detectasse 1 das constrições, que era mais suave. 


\section{CONCLUSÕES E SUGESTÕES PARA TRABALHOS FUTUROS}

O sistema desenvolvido neste trabalho é capaz de classificar automaticamente, imagens referentes a cromossomos humanos, em: normal, anel e dicêntrico. No caso de o cromossomo ser normal o sistema também é capaz de classificá-lo em metacêntrico, submetacêntrico e acrocêntrico.

Para realizar esta classificação, foi proposto um método de extração de características que se constitui de cinco etapas: 1) redimensionamento da imagem 2) cálculo das distâncias horizontais entre as bordas de cada imagem cromossômica (DHBs); 3) padronização do range (faixa de variação) dos $D H B s$; 4) identificação do limiar e binarização do vetor, e 5) redistribuição das bandas. Os vetores resultantes deste processo carregam três características fundamentais: a quantidade de bandas, o comprimento e o posicionamento de cada uma delas dentro do vetor.

A RNA desenvolvida neste trabalho foi treinada utilizando-se vetores resultantes deste processo. No mapa obtido, houve a formação nítida de 5 grupos (anel, dicêntrico, metacêntrico, submetacêntrico e acrocêntrico). De forma que cada cluster é composto somente por cromossomos do mesmo tipo, não havendo cromossomos "intrusos" (que deveriam pertencer a outro grupo) em nenhum deles. Este é um indicativo de que a partir do método de extração de características aqui proposto, a RNA identificou padrões que permitem classificá-los corretamente.

Para validação do SOM, foi utilizado um conjunto de 500 imagens de cromossomos individualizados onde foi obtida uma taxa de acerto de 93,4\% na classificação dos cromossomos em relação ao diagnóstico dado por um profissional citogeneticista.

Este trabalho apresenta uma aplicação real de prática de análise cromossômica, onde frequentemente são empregadas imagens metafásicas de baixa qualidade, neste contexto o método proposto apresentou-se hábil em amplificar as características de interesse para a distinção entre os tipos cromossômicos e consequentemente melhorar a eficiência da rede neural SOM em classificá-los.

Por meio do uso dos mapas auto-organizáveis, se propôs uma metodologia que pode ser de grande utilidade no desenvolvimento de ferramentas de auxilio a análises rotineiras feitas por profissionais citogeneticistas. 


\subsection{Sugestões para trabalhos futuros}

Uma sugestão seria utilizar o método de extração de características desenvolvido neste trabalho para o reconhecimento de outros tipos de aberrações cromossômicas, que não foram abordadas neste trabalho, como deleção terminal, deleção intersticial (double minute), e tricêntrico. Para isso, características que auxiliem a discriminação destes novos tipos cromossômicos que se deseja classificar devem ser identificadas e inseridas no vetor de entrada da RNA. Um exemplo seria acrescentar no vetor a informação referente ao tamanho dos cromossomos. No sistema atual todas as imagens de cromossomos individuais foram redimensionadas para que apresentassem 120 pixels de altura e 60 pixels de largura, e os valores referentes aos tamanhos originais das imagens cromossômicas foram descartados, entretanto esta informação poderia propiciar a diferenciação entre cromossomos com aberrações do tipo anelar e os fragmentos resultante da ocorrência da aberração do tipo deleção intersticial.

Outra sugestão seria a aplicação da metodologia aqui proposta para o desenvolvimento de ferramentas que relacionam a frequência de aberrações radioinduzidas com a estimativa de dose absorvida (dosimetria biológica).

Para a separação de cada um dos cromossomos presentes nas imagens de células metafásicas em subimagens independentes indica-se o uso de segmentação baseada em cores, conforme descrito no item 4.2.4 - Segmentação a partir de cores. Para a segmentação das imagens nos casos em que houver a presença de subconjuntos de pixels de mesmo rótulo com contagens muito altas, sugere-se realimentar a etapa de segmentação das imagens cromossômicas, pois geralmente este é um indicativo de que dois ou mais cromossomos estão sobrepostos ou conectados. Na tentativa de separar cromossomos conectados, o sistema se realimentaria, de forma que, o valor do limiar seja diminuído, a cada nova segmentação, até que a interligação por conexões de pixels se desfizesse e, com isso, fosse atribuído mais de um rótulo a este conjunto. Caso isso não ocorresse, dentro de um determinado limite de tentativas, provavelmente não se trataria de cromossomos conectados e sim sobrepostos. Neste caso seria utilizado um método de segmentação denominado Watershed (método do divisor de águas) para a separação dos cromossomos, a ideia básica deste método é dada por uma "topografia" montanhosa que separa regiões utilizando os módulos dos gradientes e as variações locais de intensidade luminosa na imagem (Kim e Kim, 2002). 
A última sugestão para trabalhos futuros seria fundir a metodologia proposta nesta dissertação com outras metodologias para classificação cromossômica, de forma que cada imagem fosse avaliada por mais de um sistema classificatório. Esta fusão entre as metodologias traria maior confiabilidade aos resultados obtidos por meio da classificação automática. 


\section{REFERÊNCIAS}

AZEVEDO, R. Processamento de imagens. Pontifícia Universidade Católica do Rio de Janeiro. 2011. Apostila para fins didáticos. Disponível em: <http://webserver2.tecgraf.pucrio.br/ mgattass/fcg/trb11/Roberto_Azevedo/main/node2.html>. Acesso em: 25 fev. 2013.

BUCKTON, K.E.; Evans, H.J. Methods for the analysis of human chromosome aberrations (World Health Organization, Switzerland) 1-66, 1973.

CAUDILL, M.; BUTLER, C. Naturally inteligent systems, Cambridge: MIT Press, 1989.

CASTRO, F.C.C.; Castro, M.C.F. Redes neurais artificiais. Pontifícia Universidade Católica do Rio Grande do Sul, 2001. Apostila para fins didáticos. Disponível em:

<http://diana.ee.pucrs.br/ decastro/RNA_hp/RNA.html>. Acesso em: 14 fev. 2011.

CHO, J. M. Chromosome classification using back propagation neural networks. Engineering in Medicine and Biology Magazine, IEEE, v. 19, n. 1, p. 28-33, 2000.

COELHO, P.R., Muniz, R., Nascimento, J., Silva, G.S.A., Siqueira P.T., Yoriyaz, H., Carneiro, V., Radiation field characterization of the NCT research facility at IEA-R1. In: 13th International Congress on Neutron Capture Therapy. 2008.

COOPER, G. M.; HAUSMAN, R.E. A célula: uma abordagem molecular. Artmed, 2007.

DA SILVA, Márcia Augusta. Dosimetria biológica em proteção radiológia: elaboracão de curvas dose-resposta para ${ }^{60} \mathbf{C O} \mathbf{E}^{{ }^{137}} \mathbf{C S}$. São Paulo: USP, 1997. 137 p. Dissertação (Mestrado) - Programa de Pós-Graduação em Tecnologia Nuclear IPEN/USP, São Paulo, 1997.

DA SILVA, Márcia Augusta. Efeito citogenético do ${ }^{153}$ Sm-EDTMP em linfócitos periféricos de pacientes com câncer metastático. São Paulo: USP, 2001. 94 p. Tese (Doutorado) - Programa de Pós-Graduação em Tecnologia Nuclear IPEN/USP, São Paulo, 2001.

DA SILVA FILHO, A. C. R. Psicologia conexionista. Ribeirão Preto: USP. Apostila para fins didáticos. 2012. Disponível em:

<http://sisne.org/Disciplinas/PosGrad/PsicoConex/aula2.pdf>. Acesso em: 7 out. 2014.

DE FARIA, E. L., Albuquerque, M. P., Alfonso, Albuquerque, M. P., Cavalcante, J. T. P. Introdução ao toolbox de redes neurais de Kohonen. Centro Brasileiro de Pesquisas Físicas, Rio de Janeiro, 2010.2 Disponível em: <http://cbpfindex.cbpf.br/publication_pdfs/nt00110.2010_04_19_16_17_29.pdf>. Acesso em: 7 out. 2014.

DE MESQUITA, R. N. Classificação de defeitos em tubos de gerador de vapor de plantas nucleares utilizando mapas auto-organizáveis. Tese (Doutorado), Escola Politécnica de Engenharia, USP, São Paulo, 2002. 
DETCHEVA E. Image processing in CAIS - an intelligent system for chromosome analysis and classification. In: R. Klette (ed.), "Computer Analysis of Images and Patterns", Proc. of the IVth International Conference CAIP'91, Akademie Verlag, Berlin, (260-264), 1991.

DETCHEVA E. Object - oriented approach to the design of CAIS - an intelligent system for chromosome analysis and classification. In: Mathematics and Education in Mathematics - Proc. of 21 Spring Conference of UBM, Sofia, April 3-6, (226-230), 1992.

DETCHEVA E. Heuristic knowledge based chromosome classification. Proc. of First National Conference INFORMATICS'94, Sofia, (83-89), 1994.

DETCHEVA E. CAIS - an intelligent system for chromosome analysis and classification. Int. Workshop "Artificial Intelligence and the Humanities", Sozopol, (4954), September 1996.

DETCHEVA E. Processing and analysis of methaphase and chromosome images. Mathematics and Education in Mathematics - Proc. of 27th Spring Conference of UBM, Sofia, (216-222), 1998.

GONZALEZ, R. C, Woods, R. E. Digital Image Processing. 2nd ed. Addison-Wesley, Reading, Mass, 1992.

GUERRA, M; De Souza, M. J. Como observar cromossomos: um guia de técnicas em citgenética vegetal, animal, e humana. Ribeirão Preto, SP : Fundação de Pesquisas Científicas de Ribeirão Preto, 2002.

HALL, E. J.; Giaccia, A. J. Radiobiology for the Radiologist. Lippincott Williams \& Wilkins, 2006.

HAYKIN, S. Neural Networks and Learning Machines. Third Edition. McMaster University. Hamilton, Ontario, Canada. 2009.

HUBER, R., Kulka, U., Lörch, Th., Braselmann, H., Engert, D., Figel, M., Bauchinger, M., Technical report: application of the Metafer2 fluorescence scanning system for the analysis of radiation-induced chromosome aberrations measured by FISHchromosome painting. Mutation Research/Genetic Toxicology and Environmental Mutagenesis, v. 492, n. 1, p. 51-57, 2001.

HSU, T.C. Human karyotypes. 1979. In: Carr, S. M. Human karyotypes.

Disponível em: <https://www.mun.ca/biology/scarr/Human_Karyotype.html>. Acesso em: 16 jun. 2014.

INTERNATIONAL ATOMIC ENERGY AGENCY. Biological dosimetry chromosomal aberrations analysis for dose assessment. (IAEA) 1986. In: DA SILVA, Márcia Augusta. Efeito citogenético do ${ }^{153} \mathrm{Sm}$-EDTMP em linfócitos periféricos de pacientes com câncer metastático. São Paulo: USP, 2001. 94 p. Tese (Doutorado) - Programa de Pós-Graduação em Tecnologia Nuclear IPEN/USP, São Paulo, 2001. p. 23. 
KASAHARA, S. Práticas de Citogenética. Sociedade Brasileira de Genética. 70p. 2003.

KELlER, J. M., Gader, P., Sjahputera, O., Caldwell, C.W; Huang, H. M. A fuzzy logic rule-based system for chromosome recognition. In: Computer-Based Medical Systems, 1995. Proceedings of the Eighth IEEE Symposium on. IEEE, 1995.

KIM, J. B.; KIM, H. J. A wavelet-based watershed image segmentation for VOP generation. In: Pattern Recognition, 2002. Proceedings. 16th International Conference on. IEEE, 2002.

KOHONEN, T. Analysis of a simple self-organizing process. Biological cybernetics, v. 44, n. 2, 1982a.

KOHONEN, T. Self-organized formation of topologically correct feature maps. Biological cybernetics, v. 43, n. 1, 1982 b.

KOHONEN, T. Self-organizing maps. Springer Science \& Business Media, 2001.

LEMM, H. O núcleo celular. 2012. Disponível em: <http://thinkbio.wordpress.com/2012/01/02/o-nucleo-celular/ >. Acesso em: 12 maio 2014.

LOPES, F. M. Introdução ao reconhecimento de padrões e aplicações em problemas de bioinformática. Universidade de São Paulo, 2012. Disponível em: <http://www.ime.usp.br/posbioinfo/cv2012/reconhecimentoPadroes_FabricioLopes.pdf.> Acesso em: 04 jun. 2014.

MALUF, S. W.; RIEGEL, M. Citogenética humana. Artmed, 2011.

MARQUES FILHO, O.; NETO, H. V. Processamento Digital de Imagens, Rio de Janeiro: Brasport, 1999.

MATHWORKS MATLAB, versão R2010a. Natick, Massachursetts: The Mathwork Inc., 2010.

METASYSTEMS Metafer, versão 2 e 4. ERP Software Provider. Altlussheim, Germany.

NASTOS, P., Paliatsos, A., Larissi, I., Moustris, K. Air Quality and Bioclimatic Conditions within the Greater Athens Area, Greece-Development and Applications of Artificial Neural Networks. INTECH Open Access Publisher, 2011.

NATARAJAN, A.T. Chromosome aberrations: past, present and future. Mutation Research/Fundamental and Molecular Mechanisms of Mutagenesis, v. 504, n. 1, p. 3-16, 2002.

NOUAILHETAS, Y. Radiações ionizantes e a vida. Rio de Janeiro, Apostila educativa. CNEN. p.42. 2000.

NUSSBAUM, R.; McInnes, R. R.; Willard H. F. Thompson\& Thompson Genetics in Medicine. ed. 6, Philadelphia: Saunders; 2004. 
OKUNO, E. Radiação: efeitos, riscos e benefícios. São Paulo: Harbra, 1988.

OKUNO, E. Efeitos biológicos das radiações ionizantes: acidente radiológico de Goiânia. Estud. av., São Paulo, v. 27, n. 77, 2013 .

PEREIRA, R. Inversões cromossômicas. Universidade Católica de Brasília. 2010. Disponível em: <http://pt.slideshare.net/rinaldowp/inverses-cromossmicas-3313686>. Acesso em: 12 maio 2014.

PFEFFERMANN, D. Inference under informative sampling. Sample Surveys: Inference and Analysis, 2009.

ROMM, H., Ainsbury, E., Barnard, S., Barrios, L., Barquinero, J. F., Beinke, C. Wojcik, A. Automatic scoring of dicentric chromosomes as a tool in large scale radiation accidents. Mutation Research/Genetic Toxicology and Environmental Mutagenesis, v. 756, n. 1, p. 174-183, 2013.

ROSENBLATT, F. Principles of neurodynamics: perceptrons and the theory of brain mechanisms. Washingthon DC: Spartan Books, 1961.

SHAFFER, L. G., McGowan-Jordan, J., \& Schmid, M. ISCN 2013: An International System for Human Cytogenetic Nomenclature (2013). Karger Medical and Scientific Publishers, 2013.

SOMASUNDARAM, D.; Kumar, V. V.Separation of overlapped chromosomes and pairing of similar chromosomes for karyotyping analysis. Measurement, v. 48, p. 274$281,2014$.

SOUZA, L. P. Análise morfológica de imagens e classificação de aberrações cromossômicas por meio de lógicas Fuzzy. São Paulo: USP, 2011. 78 p. Dissertação (Mestrado) - Programa de Pós-Graduação em Tecnologia Nuclear IPEN/USP, São Paulo, 2011.

TOU, J. T.; R. C. Gonzalez. Pattern Recognition Principles. Reading, Massachusetts: Addison Wesley Publishing Company. 1974.

TSOUKALAS, L.H.; Uhrig, R.E. Fuzzy and neural approaches in engineering. New York: John Wiley \& Sons, 1996.

TURNER, M.; Austin, J.; Allinson, N. M.; Thompson, P. Chromosome location and feature extraction using neural networks. Image and Vision Computing, 11, $\mathrm{n}^{\mathrm{o}} .4, \mathrm{p}$. 235-239, 1993.

WANG, X., Zheng, B. Li, S., Mulvihill, J. J., Wood, M. C., Liu, H. Automated classification of metaphase chromosomes: Optimization of an adaptive computerized scheme. Journal of Biomedical Informatics 42. p. 22-31, 2009.

VALGÔDE, F. G. S. Avaliação do dano radioinduzido, capacidade de reparo e morte celular em células humanas tumorais (T-47D e MCF-7) e não tumorais (MCF-10) de 
mama. Dissertação (Mestrado) - Instituto de Pesquisas Energéticas e Nucleares. Universidade de São Paulo. 2008.

VASCONCELOS, Beatriz. Estudo da frequência de aberrações cromossômicas nos pacientes atendidos na Unidade de Genética do Instituto da Criança entre 1992 a 2002. p.83. Dissertação (Mestrado) - Faculdade de Medicina. Universidade de São Paulo, São Paulo. 2007.

VESANTO, J.; Himberg, J.; Alhoniemi, E.; Parhankangas, J. Self-organizing map in Matlab: the SOM Toolbox. Laboratory of Computer and Information Science, Helsinki University of Technology, Finland. 2000a.

VESANTO, J.; Himberg, J.; Alhoniemi, E.; Parhankangas, J. SOM Toolbox for Matlab 5. Laboratory of Computer and Information Science, Helsinki University of Technology, Finland. 2000b.

VESANTO, J.; Alhoniemi, E. Clustering of the Self-Organizing Map. IEEE Transactions On Neural Networks, v. 11, $\mathrm{n}^{\circ}$. 3, May 2000, Helsinki University of Technology, Finland. 2000. 